UNIVERSIDADE DE SÃO PAULO

ESCOLA DE ENGNEHARIA DE SÃO CARLOS

CRISTIANE ARRUDA DE OLIVEIRA

DIGESTÃO ANAERÓBIA TERMOFÍLICA DO MELAÇO DE CANA-DE-AÇÚCAR EM REATORES DE LEITO FIXO ESTRUTURADO DE DUAS FASES E FASE ÚNICA PARA A PRODUÇÃO DE BIOGÁS

VERSÃO CORRIGIDA

São Carlos

2018 



\section{DIGESTÃO ANAERÓBIA TERMOFÍLICA DO MELAÇO DE CANA-DE-AÇÚCAR EM REATORES DE LEITO FIXO ESTRUTURADO DE DUAS FASES E FASE ÚNICA PARA A PRODUÇÃO DE BIOGÁS}

Dissertação apresentada à Escola de Engenharia de São Carlos, da Universidade de São Paulo, como parte dos requisitos para a obtenção do título de Mestre em Ciências: Engenharia Hidráulica e Saneamento

Orientadora: Prof ${ }^{a}$. Dr ${ }^{\mathrm{a}}$. Márcia Helena Rissato Zamariolli Damianovic

São Carlos 


\begin{abstract}
AUTORIZO A REPODUÇÃO TOTAL OU PARCIAL DESTE TRABALHO, POR QUALQUER MEIO CONVENCIONAL OU ELETRÔNICO, PARA FINS DE ESTUDO E PESQUISA, DESDE QUE CITADA A FONTE.
\end{abstract}

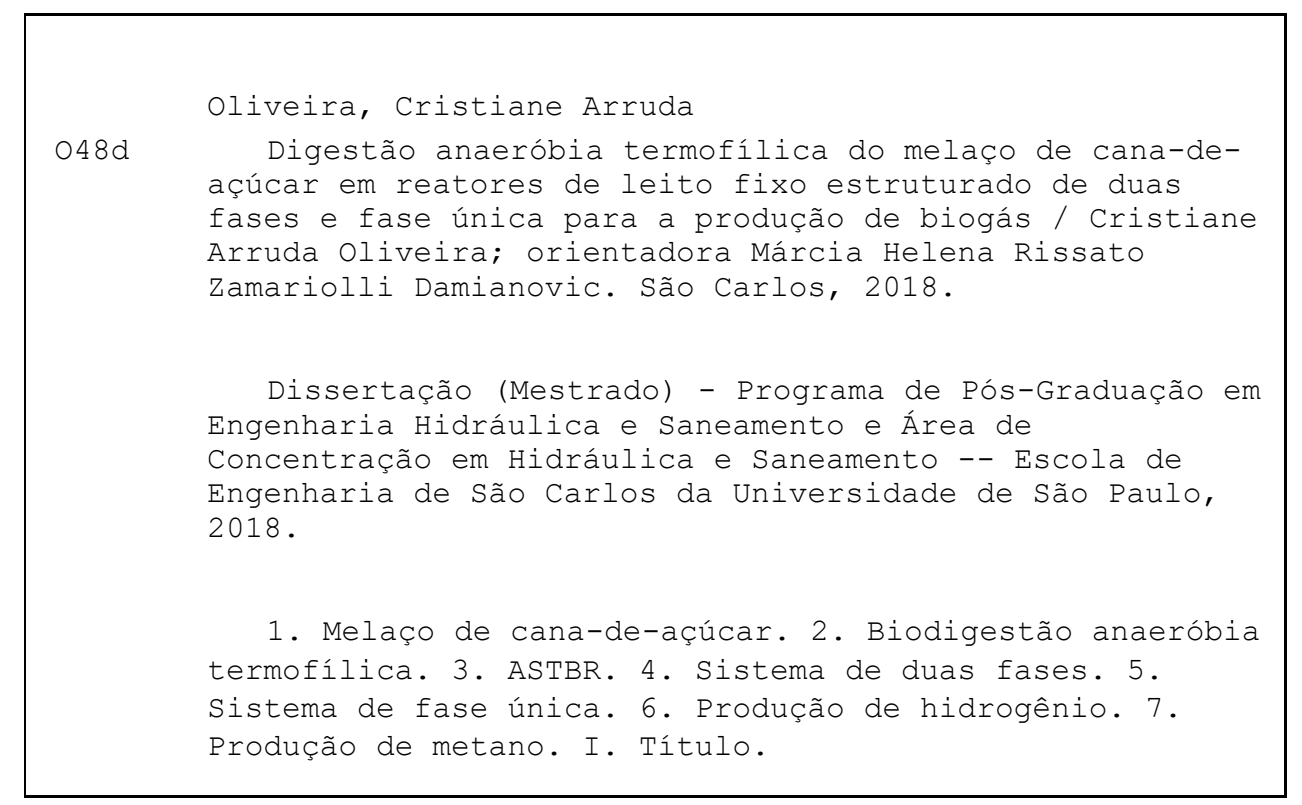




\section{FOLHA DE JULGAMENTO}

Candidata: Engenheira CRISTIANE ARRUDA DE OLIVEIRA.

Título da dissertação: "Digestão termofílica do melaço de cana-de-açúcar em reatores de leito fixo estruturado de duas fases e fase única para a produção de biogás".

Data da defesa: 11/05/2018.

Comissão Julgadora:

Resulfado:

Profa. Dra. Márcia Helena Rissato Zamariolli Damianovic (Orientadora)

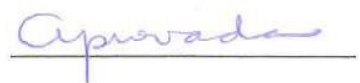

(Escola de Engenharia de São Carlos/EESC)

Dr. Antônio Djalma Ferras Junior

Aprovade

(Laboratório Nacional de Ciência e Tecnologia do Bioetanol/CTBE)

Profa. Dra. Simone Damasceno Gomes

(Universidade Estadual do Oeste do Paraná/UNIOESTE)

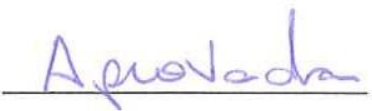

Coordenador do Programa de Pós-Graduação em Engenharia Hidráulica e Saneamento:

Prof. Dr. Eduardo Mario Mendiondo

Presidente da Comissão de Pós-Graduação:

Prof. Associado Luís Fernando Costa Alberto 

Aos meus avós (in memoria), Luiz e Nelly, que foram grandes inspiradores na arte de aprender. Aos meus pais, Miguel e Célia, por todo amor e dedicação. Aos meus irmãos, Gustavo e Thais, por todo apoio. 



\section{AGRADECIMENTOS}

À Deus, por estar sempre presente em minha vida, me iluminando em cada passo da minha jornada.

À minha família, principalmente: Miguel, Célia, Gustavo, Thais, Rafael, Eduardo, Paula, Orlando, Valdomira e Andressa. Aos meus pais, Miguel e Célia, por todo carinho, amor, dedicação, mas principalmente por me incentivarem na busca constante pelo conhecimento. Aos meus irmãos, Gustavo e Thais, por todos os conselhos e apoio durante toda minha jornada. Ao meu companheiro, Rafael, por me ensinar a ser uma pessoa melhor, por todo carinho, paciência e atenção desmedidos. Aos meus cunhados, Eduardo e Paulo, por todo auxílio. Aos meus avós, Orlando e Valdomira por todo carinho. E a Andresa, por todo cuidado com a minha família, incluindo a Luna, Ted e o Billy.

À minha orientadora, Márcia, por ter acreditado em mim, por todos os conselhos, compreensão e "puxões de orelha". Márcia, você não é só um exemplo de grande profissional, mas também uma grande inspiração de mulher e mãe. Tenho orgulho em fazer parte do seu grupo.

Aos professores, Marcelo Zaiat e Eugênio Foresti, por todo conhecimento e ensinamentos, principalmente nas horas de maiores dificuldades durante o desenvolvimento desse trabalho.

Aos grandes amigos do LPB: Carol e Mirabelle ("as cabritas"), por todos conselhos, risadas, reflexões, e por me ajudarem nas horas difíceis. A Carla, Leandro, Lais e Rodrigo, por toda atenção, disposição e sugestões que me ajudaram a crescer ao longo desses anos. Ao Lucas, grande exemplo de profissional e de ser humano, por deixar os dias no laboratório mais divertidos, mas também por me ensinar tanto, você foi uma das principais bases para construção do meu conhecimento nesse trabalho. Ao Cebola, Elias, Elis, Fabrício, Gui Oliveira, Gui Soares, Jéssica Lopes, Mirian, Moara, Murilo, Rachel, Raphaella, Renata, Rogério, Vivian e Williane pelos conselhos e por terem me ajudando com os problemas diários em laboratório. Sou muito grata a todos vocês.

Ao Lucas, Drica e Professor Foresti pelas correções e sugestões na qualificação.

À Janja, Carol Sabatini, Eloísa e Isabel por toda ajuda.

Ao Paulo, pela orientação na iniciação cientifica e por me ajudar no amadurecimento acadêmico.

À CAPES, pela concessão da bolsa. Ao CNPq e FAPESP por todo investimento.

Meus sinceros agradecimentos! 



\section{RESUMO}

OLIVEIRA, C. A. Digestão anaeróbia termofílica do melaço de cana-de- açúcar em reatores de leito fixo estruturado de duas fases e fase única para a produção de biogás. 2018. 136p. Dissertação (mestrado) - Escola de Engenharia de São Carlos, Universidade de São Paulo, São Carlos, 2018.

O Brasil é o maior produtor de cana-de-açúcar, e entre os principais subprodutos dessa indústria está o melaço de cana-de-açúcar. Esse substrato é rico em carboidratos, apresentando potencial para ser utilizado na digestão anaeróbia para geração de biogás. Neste estudo, priorizou-se a produção de biogás em condições termofílicas $\left(55^{\circ} \mathrm{C}\right) \mathrm{com}$ a finalidade de comparação do sistema de duas fases (reator acidogênico seguido de reator metanogênico) e sistema de fase única (acidogênico e metanogênico em uma mesma unidade), utilizando o melaço como substrato. O sistema de duas fases baseou-se na separação da acidogênese e metanogênese. O reator acidogênico (ASTBR -A) foi operado com carga orgânica volumétrica (COV) de $60,0 \mathrm{~g} \mathrm{~L}^{-1} \mathrm{~d}^{-1}$ e tempo de detenção hidráulico (TDH) de 4 horas. O reator metanogênico, sequencial ao acidogênico (ASTBR - M II) foi operado em dez fases, com COV variando de 0,6 a 10,0 $\mathrm{g} \mathrm{L}^{-1} \mathrm{~d}^{-1}$ e TDH de 40 e 24 horas. O sistema de fase única foi composto por um reator metanogênico (ASTBR - M I) operado em nove fases com COV entre 2,5 e 10,0 $\mathrm{g} \mathrm{L}^{-1} \mathrm{~d}^{-1}$ e TDH de $28 \mathrm{~h}$. Bicarbonato de sódio $\left(\mathrm{NaHCO}_{3}\right)$ foi adicionado na proporção de $1,00 \mathrm{gNaHCO}_{3} \mathrm{~g}^{-1} \mathrm{DQO}$ para todas as fases do ASTBR - M II. Para o ASTBR - M I, variou-se a concentração de 1,00 a 0,00 gNaHCO$_{3} \mathrm{~g}^{-}$ ${ }^{1}$ DQO no reator. Para o ASTBR - A a porcentagem de hidrogênio $\left(\mathrm{H}_{2}\right)$ no biogás foi de $51 \%$, a produção volumétrica de hidrogênio $(\mathrm{PVH})$ de $88,0 \mathrm{mLH}_{2} \mathrm{~L}^{-1} \mathrm{~h}^{-1}$ e o rendimento de hidrogênio (HY) de $1,18 \mathrm{molH}_{2} \mathrm{~mol}_{\text {carboidratos }}{ }^{-1}$. O microrganismo predominante nesse reator foi o Thermoanaerobacterium, e a principal rota a do ácido lático. O reator ASTBR - M I sofreu acidificação após a retirada completa de alcalinizante, permitindo a detecção de $\mathrm{H}_{2}$ no biogás. Porém, a retomada da adição de $\mathrm{NaHCO}_{3}$ favoreceu o crescimento das arqueias, principalmente metanogênicas hidrogenotróficas. A comparação dos reatores metanogênicos foi realizada para fases com condições semelhantes (COV de $10 \mathrm{~g} \mathrm{~L}^{-1} \mathrm{~d}^{-1} \mathrm{e}$ $\left.1,00 \mathrm{gNaHCO}_{3} \mathrm{~g}^{-1} \mathrm{DQO}\right)$ e permitiu verificar melhor desempenho na produção de $\mathrm{CH}_{4}$ do ASTBR - M II. Em relação ao MY, a eficiência do ASTBR - M II foi $44 \%$ superior ao ASTBR M - I.

Palavras-chave: ASTBR. Biodigestão anaeróbia termofílica. Melaço de cana-de-açúcar. Produção de hidrogênio. Produção de Metano. Sistema de duas fases. Sistema de fase única. 



\begin{abstract}
OLIVEIRA, C. A. Thermophilic anaerobic digestion of sugarcane molasses in structured fixed bed reactors in two-phases and single-phase for biogas production. 2018. 136p. Dissertação (mestrado) - Escola de Engenharia de São Carlos, Universidade de São Paulo, São Carlos, 2018.
\end{abstract}

Brazil is the largest producer of sugarcane and one of the main sub-products of this industry is the molasses, which is rich in carbohydrates and can be used as a substrate for biogas production in anaerobic digestion. In this study, biogas production was evaluated under thermophilic conditions $\left(55^{\circ} \mathrm{C}\right.$ ) in a two-phases system (acidogenic reactor followed by methanogenic reactor) based on phase separation and a single-phase system (acidogenic and methanogenic microorganisms in a single unit) using molasses as the substrate. The acidogenic reactor (ASTBR-A) was operated under the organic loading rate (OLR) of $60.0 \mathrm{~g} \mathrm{~L}^{-1} \mathrm{~d}^{-1}$ and hydraulic retention time (HRT) of 4 hours. The methanogenic reactor (ASTBR - M II), which was sequential to acidogenic one, was operated in ten phases with OLR ranging from 0.6 to $10.0 \mathrm{~g} \mathrm{~L}^{-1} \mathrm{~d}^{-1}$ and HRT of 40 and 24 hours. The single-phase reactor was composed of a methanogenic reactor (ASTBR - M I) operated in nine phases with increasing OLR from 2.5 to $10.0 \mathrm{~g} \mathrm{~L}^{-1} \mathrm{~d}^{-1}$ and HRT of 28 hours. Sodium bicarbonate $\left(\mathrm{NaHCO}_{3}\right)$ was added in the ratio of $1.00 \mathrm{gNaHCO}^{3} \mathrm{~g}^{-1} \mathrm{COD}$ in all phases of ASTBR-M II. For the ASTBR-M I, the concentration varied between 1.00 to 0.00 $\mathrm{gNaHCO}^{3} \mathrm{~g}^{-1} \mathrm{COD}$. In the ASTBR - A, the percentage of hydrogen $\left(\mathrm{H}_{2}\right)$ in the biogas was $51 \%$, the volumetric hydrogen production (VHP) was $88.0 \mathrm{mLH}_{2} \mathrm{~L}^{-1} \mathrm{~h}^{-1}$ and the hydrogen yield (HY) was $1.18 \mathrm{molH}_{2}$ molar $^{-1}$ carbohydrate. The predominant microorganism in this reactor was the Thermoanaerobacterium and the main metabolite route was the lactic acid. The ASTBR - M I suffered acidification after the complete removal of the alkalinizer allowing the detection of hydrogen in the biogas. However, the use of the alkalinizer after its complete removal from the system favored the growth of Archaeas, mainly the hydrogenotrophic methanogens. The comparison of the methanogenic reactors was carried out for phases with similar conditions (OLR of $10 \mathrm{~g} \mathrm{~L}^{-1} \mathrm{~d}^{-1}$ and $1.00 \mathrm{gNaHCO}_{3} \mathrm{~g}^{-1} \mathrm{COD}$ ) and allowed to verify a better performance in the methane $\left(\mathrm{CH}_{4}\right)$ production in the ASTBR-M II. Regarding the methane yield (MY), the efficiency of ASTBR - M II was 44\% higher than ASTBR M - I.

Keywords: ASTBR. Production of hydrogen. Production of Methane. Single-phase system. Sugarcane molasses. Thermophilic anaerobic biodigestion. Two-phases system. 



\section{LISTA DE FIGURAS}

Figura 3.1-Fluxograma simplificado das etapas de produção de álcool e açúcar a partir da cana-de-açúcar (adaptado de MORAES et al., 2015)......................................................... 36

Figura 4.1 - Fluxograma das etapas experimentais 56

Figura 4.2 Detalhes do reator ASTBR - A: (A) Estrutura do reator, com ponto de entrada e saída; (B) Espuma de poliuretano utilizado como meio suporte da biomassa fixas em tela de aço inoxidável.

Figura 4.3 - Detalhes do reator ASTBR - M II. (A) desenho esquemático do sistema combinado em série;(B) Imagem dos reatores ASTBR - A e ASTBR - M I alocados na câmara climatizada; (C) Imagem da alimentação do sistema.

Figura 4.4 - Desenho esquemático do reator metanogênico do sistema único (ASTBR - M

I)

Figura 5.1 - Variação do pH afluente e efluente do reator ASTBR - A. Legenda: - $-\mathrm{pH}$

afluente. - $\bullet-\mathrm{pH}$ efluente .75

Figura 5.2 - (A)Variação temporal da eficiência de remoção de matéria orgânica; (B) variação temporal de conversão de carboidratos no reator ASTBR - A. Legenda: - Remoção de DQOt (\%); -n- remoção de DQOs (\%); - - - Conversão de CHt (\%); - $\mathbf{\Lambda}$ -

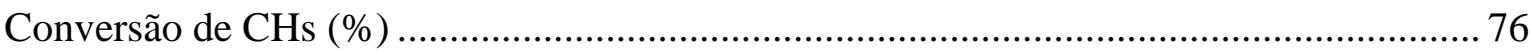

Figura 5.3 - Composição do biogás do reator ASTBR - A, Legenda: - $\square-\mathrm{H}_{2}(\%)$; - $\square-$ $\mathrm{CO}_{2}(\%)$

Figura 5.4 - (A) Vazão de biogás; (B) Produção volumétrica de $\mathrm{H}_{2}$; (C)Rendimento de $\mathrm{H}_{2}$

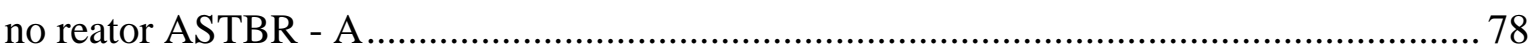

Figura 5.5 - Box-plot da concentração dos metabólitos do reator ASTBR - A.................... 79 Figura 5.6 - Proporção dos metabólitos da fermentação na fase solúvel do reator ASTBR A

Figura 5.7 - Balanço de massa para a fase solúvel do efluente do reator ASTBR - A....... 81

Figura 5.8 Biomassa acidogênica. (A) Espuma de poliuretano com biomassa aderida;(B) Biomassa suspensa

Figura 5.9 - Abundância relativa do principais gêneros na biomassa suspensa e aderida do reator ASTBR - A

Figura 5.10 Variação temporal do rendimento de $\mathrm{H} 2$ de acordo com a geração de ácido acético, lático e butírico. 
Figura 5.11 - (A) pH; (B) Variação dos ácido totais voláteis e COV; (C) Relação AI/Ap

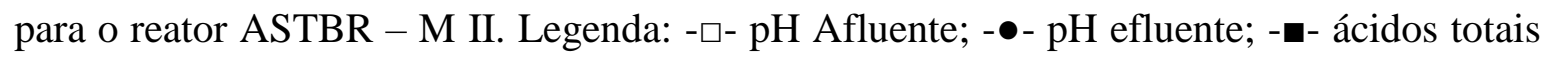
afluente; - - ácidos totais efluente; - $\Delta$ - COV; - $\diamond$-relação AI/Ap.

Figura 5.12 - Variação temporal da eficiência de remoção de matéria orgânica do reator ASTBR - M II. Legenda: - o- remoção DQOt; --- Remoção DQOs 88

Figura 5.13 - Composição do biogás no reator ASTBR - M II. Legenda: -ロ- CH4 (\%); -๑$\mathrm{CO} 2(\%)$

Figura 5.14 - (A) Vazão do biogás medido e esperado; (B) Rendimento de metano no reator ASTBR - M II. Legenda: -๑- VBG medido;- $\boldsymbol{\Delta}$ - VBG esperado 91

Figura 5.15 - (A) Concentração de metabólitos; (B) proporção de metabólitos no efluente do reator ASTBR - M II 95

Figura 5.16 - Balanço de massa para a fase solúvel do efluente do reator ASTBR - M II . 96 Figura 5.17 - (A) pH; (B) Variação dos ácido totais voláteis e COV; (C) Relação AI/Ap para o reator ASTBR - M I. Legenda: -ロ- pH afluente; -•- pH efluente; - $\square$ - concentração de ácidos totais afluente; - - concentração de ácido totais efluente; - $\Delta$ - COV; - $\diamond$ - AI/Ap . 99 Figura 5.18 - Eficiência de remoção de matéria orgânica no reator ASTBR - M I. Legenda: - - Remoção de DQOt (\%); -匹- Remoção de DQOs (\%) 100 Figura 5.19 Composição do biogás no reator ASTBR - M I. Legenda:- $\Xi_{-} \mathrm{H}_{2}(\%)$; - - $\mathrm{CH}_{4}$ $(\%) ;-\mathbf{m}-\mathrm{CO}_{2}(\%)$ 101

Figura 5.20 - (A) Vazão do biogás medido e esperado; (B) Produção volumétrica de metano; (C) Rendimento de metano no reator ASTBR - M I. Legenda: - $\square-$ VBG medido;$\Delta$ - VBG esperado. 103

Figura 5.21 - (A) Concentração de metabólitos; (B) proporção de metabólitos no efluente do reator ASTBR - M I 106 Figura 5.22 - Balanço de massa para a fase solúvel do efluente do reator ASTBR - M I 109 Figura 5.23 - Comparação em box-plot entre os reatores metanogênicos. (A) Eficiência de remoção de DQOt; (B) Eficiência de remoção de DQOs;(C) relação alcalinidade intermediaria e parcial - AI/Ap. Legenda: ASTBR - M II ( $)$ e ASTBR - M I (口) ........ 113 Figura 5.24 - Composição do biogás para os reatores ASTBR - M II e ASTBR - M I. Legenda: $\% \mathrm{CH}_{4}(\square), \% \mathrm{CO}_{2}($ (в). 114 Figura 5.25 - Box-plot para comparação da produção de biogás nos reatores metanogênicos. (A) Vazão de biogás; (B) Produção volumétrica de metano; (C) Vazão 
molar de metano; (D) Rendimento de metano. Legenda: ASTBR - M II ( $)$ e ASTBR - M I (

Figura 5.26 - (A) Biomassa aderida ao material suporte do reator metanogênico; (B) biomassa suspensa do reator metanogênico

Figura 5.27 - Dendograma do domínio Bacteria para os reatores ASTBR - M I e ASTBR M II

Figura 5.28 - Dendograma do domínio Archaea para os reatores ASTBR - M II e ASTBR M I 120

Figura 5.29 - Balanço energético a partir dos parâmetros de desempenho dos reatores ASTBR-A, ASTBR-M II e ASTBR- M I. (A) Potencial energético para o sistema de duas fases; (B) Potencial energético para sistema de fase única. 



\section{LISTA DE TABELAS}

Tabela 3.1 - Comparação do rendimento de H2 a partir de diferentes substratos e temperaturas.

Tabela 3.2 - Comparação do rendimento de $\mathrm{CH}_{4}$ a partir de diferentes substratos e temperaturas.

Tabela 3.3 - Composição química do melaço de cana de açúcar 42

Tabela 3.4 - Composição do biogás. Fonte: adaptado de CASSINI (2003).

Tabela 4.1 - Caracterização físico-química do melaço (coleta 2015 e 2016). 53

Tabela 4.2 - Condições operacionais aplicadas ao reator ASTBR - A............................... 58

Tabela 4.3 - Solução de nutrientes. 60

Tabela 4.4 - Solução de vitaminas ( Fonte: Touzel e Albagnac, 1983). 60

Tabela 4.5 - Condições operacionais aplicadas ao reator ASTBR - M II 61

Tabela 4.6 - Condições operacionais aplicadas ao reator ASTBR - M I. 63

Tabela 4.7 - Análises e métodos analíticos para monitoramento dos reatores 66

Tabela 4.8 - Principais equações utilizadas para verificação do desempenho dos reatores 68 Tabela 4.9 - Fatores de equivalência dos ácidos e carboidratos em termos de DQO......... 71

Tabela 5.1 - Média dos parâmetros de monitoramento do reator metanogênico ASTBR - M II para cada fase .92

Tabela 5.2 - Concentração de ácidos orgânicos no efluente do reator ASTBR - M II ....... 94 Tabela 5.3 - Média dos parâmetros de monitoramento do reator metanogênico ASTBR - M I para cada fase 104

Tabela 5.4 - Concentração de ácidos orgânicos no efluente do reator ASTBR - M I ...... 107 Tabela 5.5 - Concentrações de $\mathrm{NaHCO}_{3}$ para a digestão da vinhaça e melaço de cana-deaçúcar em sistemas anaeróbios....

Tabela 5.6 - Diferenças operacionais entre as fases VIII e III dos reatores metanogênicos ASTBR - M II e ASTBR - M I

Tabela 5.7 - Comparação dos principais parâmetros entre reatores metanogênicos dos sistema combinado (ASTBR - M II) e sistema único (ASTBR - M I)

Tabela 5.8 - Índice de dominância (D) e Shannon (H) para o domínio Bacteria 119

Tabela 5.9 - Índice de dominância (D) e Shannon (H) para o domínio Archaea 121 



\section{LISTA DE ABREVIATURAS E SIGLAS}

\% CH: eficiência de remoção de carboidratos

\% CH4: porcentagem de metano no biogás

\% CO2: porcentagem de gás carbônico no biogás

\%DQO: eficiência de remoção de DQO

\% $\mathbf{H}_{2}$ : porcentagem de hidrogênio no biogás

AF: anaerobic filter (filtro anaeróbio)

AGV: ácidos graxos voláteis

AI: alcalinidade intermediária

ANEEL: Agência Nacional de Energia Elétrica

AnSBBR: reator anaeróbio operado em bateladas sequenciais

Ap: alcalinidade parcial

APBR: anaerobic packed-bed reactor (reator anaeróbio de leito empacotado)

APHA: American Public Health Association (Associação amaericana de saúde pública)

ASTBR - A: reator anaeróbio de leito fixo estruturado acidogênico do sistema combinado ASTBR - M I: reator anaeróbio de leito fixo estruturado metanogênico do sistema de fase única

ASTBR - M II: reator anaeróbio de leito fixo estruturado metanogênico do sistema de duas fases

ASTBR: anaerobic structured-bed reactor (reator anaeróbio de leito estruturado)

BM: balanço de massa

CH,CHt: concentração de carboidratos totais

CHs: concentração de carboidratos solúveis

CNTP: condição normal de temperatura e pressão 
CONAB: Companhia Nacional de Abastecimento

COT: Carbono orgânico total

COV: carga orgânica volumétrica

CSTR: continuously stirred-tank reactor (reator anaeróbio de mistura completa)

DBO: demanda bioquímica de oxigênio

DGGE: Denaturating Gradiente Gel Electrophoresis (Eletroforese em Gel de Gradiente desnaturante)

DQO,DQOt: demanda química de oxigênio total

DQOs: demanda química de oxigênio solúvel

EGSB: expanded granular sludge-bed reactor (reator de leito expandido granular)

ESSC: Escola de Engenharia de São Carlos

GC: cromatografia gasosa

HAc: ácido acético

HBu: ácido butírico

HLc: ácido lático

HPLC: cromatografia líquida de alta eficiência

HPr: ácido propriônico

HY: rendimento de hidrogênio

IBRCS: integrated biohydrogen reactor clarifier systems (Sistema integrado de clarificador de biohidrogênio)

LPB: Laboratório de Processos Biológicos

MY: rendimento de mentano

$\mathrm{NaHCO}_{3}$ : bicarbonato de sódio

NaOH: Hidróxido de sódio 
nd: valor não disponível

NTK: nitrogênio total kjekdahl

PCR: Polymerase Chain Reaction (reação em cadeia da polimerase)

PE: potencial energético

PVH: produção volumétrica de hidrogênio

PVM: produção volumétrica de metano

SST: sólidos suspensos totais

SSV: sólidos suspensos voláteis

SV: sólidos voláteis

TDH: tempo de detenção hidráulico

UASB: upflow anaerobic sludge blanket reactor (reator anaeróbio de fluxo ascendente e manta de lodo)

USP: Universidade de São Paulo

VBG: vazão do biogás

VMH: vazão molar de hidrogênio

VMM: vazão molar de metano 



\section{SUMÁRIO}

1 INTRODUÇÃ O

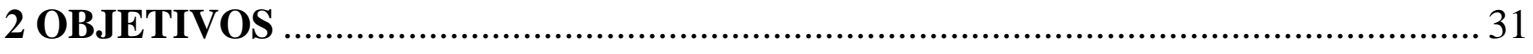

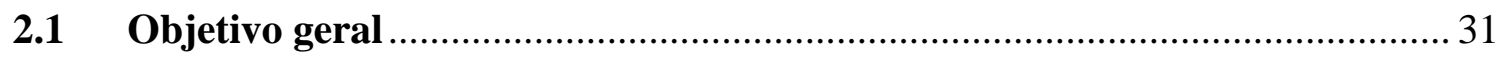

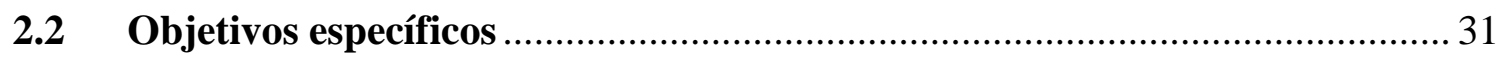

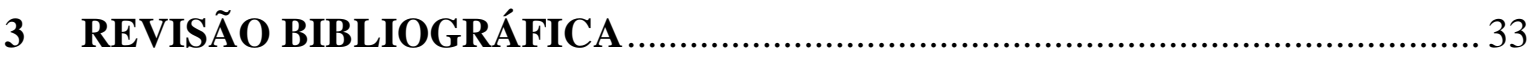

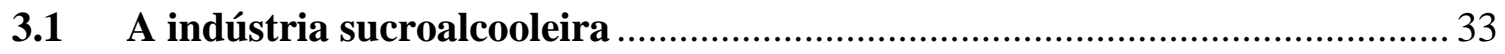

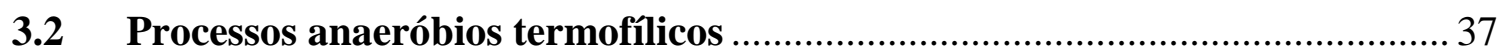

3.3 Produção de biogás a partir do melaço ………………………………………..... 42

3.4 Produção de biogás em sistemas de duas fases................................................ 45

3.5 Produção de metano em reator de fase única.................................................... 47

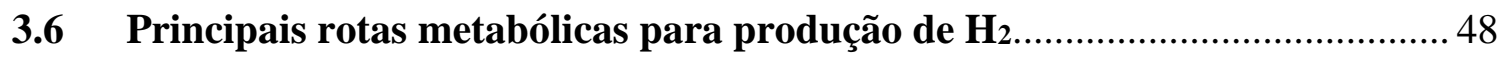

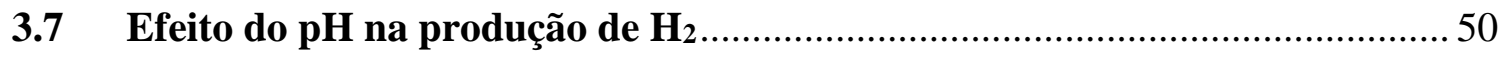

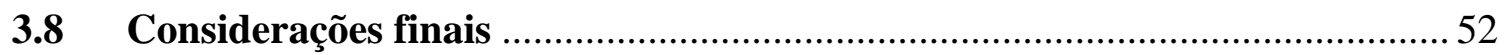

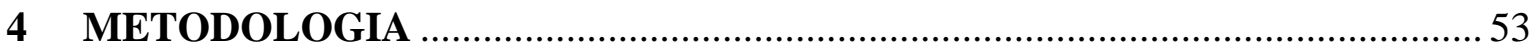

4.1 Caracterização das amostras de melaço de cana-de-açúcar ..............................53

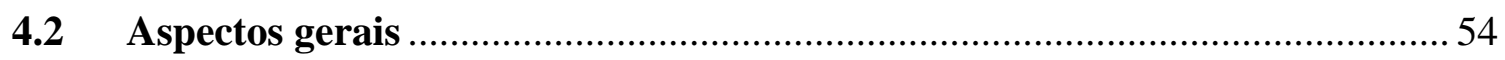

4.3 Procedimentos experimentais: Reatores e condições operacionais ................. 55

4.3.1 Reator acidogênico (ASTBR-A) - sistema de duas fases ......................................56

4.3.2 Reator metanogênico - sistema de duas fases (ASTBR-M II).............................. 58

4.3.3 Reator metanogênico - sistema de fase única (ASTBR-M I) ………………….... 61

4.4 Avaliação do desempenho dos reatores: Métodos analíticos e cálculos ........63

4.4.1 Balanço de massa nos sistemas de reatores........................................................... 70

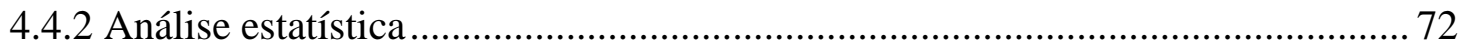

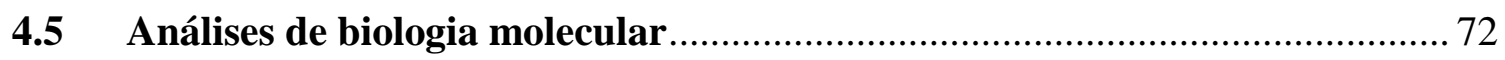

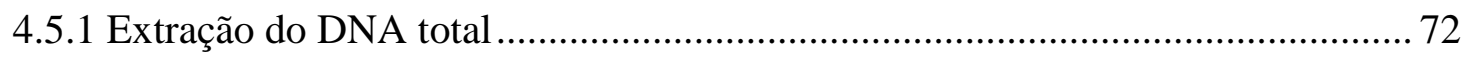

4.5.2 Reação em Cadeia da Polimerase (PCR) …………………………………...... 73 
4.5.3 Eletroforese em gel com gradiente desnaturante (DGGE) .............................. 73

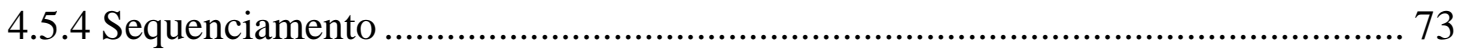

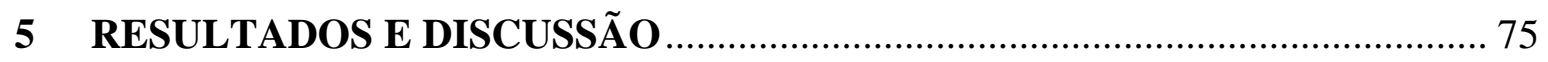

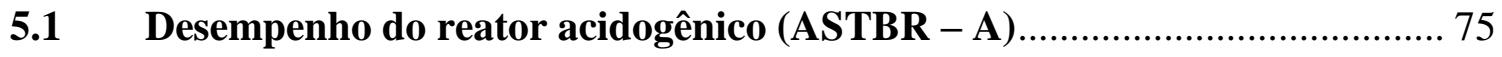

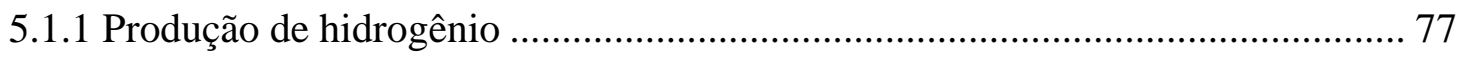

5.1.2 Avaliação dos produtos intermediários........................................................ 79

5.1.3 Estrutura das comunidades microbianas na fase acidogênica.......................... 81

5.2 Desempenho do reator metanogênico - sistema de duas fases (ASTBR - M

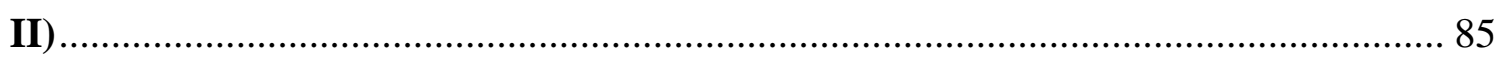

5.2.1 Produção de metano em ASTBR - M II ...................................................... 89

5.2.2 Avaliação dos produtos intermediários em ASTBR - M II............................. 93

5.3 Desempenho do reator metanogênico - sistema de fase única (ASTBR- M I)

5.3.1 Produção de metano em ASTBR - M I ....................................................... 100

5.3.2 Avaliação dos produtos intermediários e efeito do alcalinizante no reator

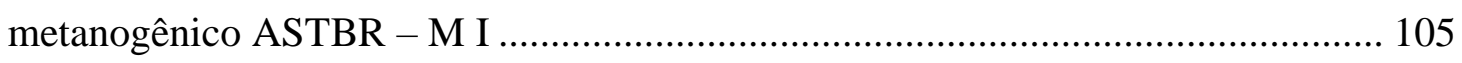

5.4 Análise e comparação dos sistemas de duas fases (ASTBR-M II) e fase única (ASTBR- M I).

5.4.1 Comparação da produção de $\mathrm{CH}_{4}$ no sistema de duas fases e no sistema de fase única 114

5.4.2 Apresentação das estruturas microbiológicas nos reatores metanogênicos de segunda fase e de fase única ao final da operação de cada sistema ........................... 118

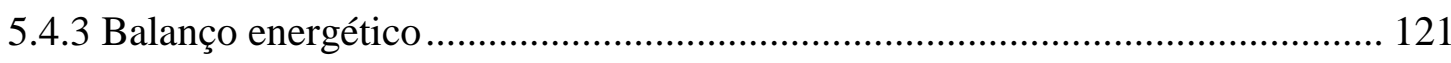

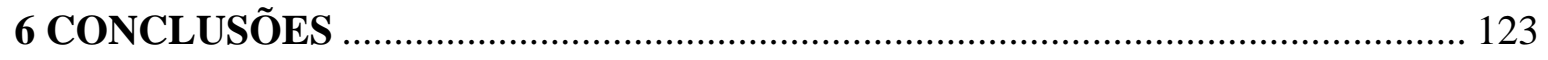

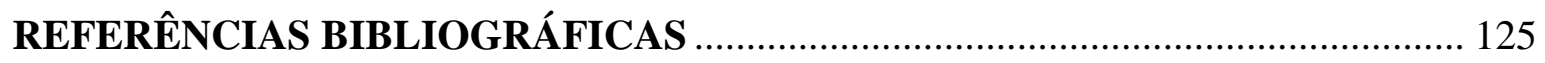




\section{INTRODUÇÃO}

A busca por fontes alternativas e renováveis de energia tem incentivado a investigação da capacidade energética de diferentes substratos. Entre esses se destacam os subprodutos da cana-de-açúcar, abundantemente gerados no Brasil.

As condições favoráveis para o cultivo da cana, como a disponibilidade de território, solo, clima, baixo custo de produção, crescimento de tecnologia, tornam o setor sucroalcooleiro brasileiro ainda em expansão (GOES; MARRA; SILVA, 2008). Diante disso, para safra de 2016/2017 a Companhia Nacional de Abastecimento (CONAB, 2016) estimou uma área ocupada pela cana-de-açúcar de 9,1 milhões de hectares, o que equivale a um aumento de 5,3\% em relação à safra 2015/2016. A região Sudeste é a maior produtora de cana, representando $62,7 \%$ de toda produção brasileira, sendo o estado de São Paulo, responsável por 52,4\%.

De acordo com FERRAZ JR. (2013), esse setor apresenta atividades que interferem na sustentabilidade ambiental, e por isso devem ser analisadas cuidadosamente, sendo elas: sistema de cogeração de potência e vapor; utilização da água; e a destinação dos resíduos. A vinhaça está entre os principais resíduos gerados durante a produção do etanol, e é utilizada em altas taxas na fertirrigação dos solos, ocasionando toxicidade e alteração de características físico-químicas mesmos. Devido a essa problemática, a vinhaça é o principal subproduto da cana estudado com vistas à digestão anaeróbia. Entretanto os demais resíduos agroindustriais da produção de álcool e açúcar, como o bagaço, caldo e melaço também apresentam potencial para aplicação da digestão anaeróbia, visando a geração de metano.

O melaço é um subproduto da produção de açúcar, utilizado para a produção de álcool em usinas anexas (produção de álcool e açúcar). Sua composição é rica em carboidratos, aproximadamente $45 \%$ de açúcares $(36 \%$ de sacarose, $6 \%$ de frutose e $3 \%$ de glicose) (KESKIN; HALLENBECK, 2012). Os carboidratos são uma fonte de carbono facilmente degradada pelos microrganismos, sendo uma boa alternativa de substrato para reatores anaeróbios.

A digestão anaeróbia é um processo auto-regulado (MOSEY, 1983) que envolve diferentes comunidades microbiológicas para decomposição da matéria orgânica. Além de reduzir consideravelmente a matéria orgânica, esse processo gera produtos gasosos como 
metano e gás carbônico. Ao realizar a separação de fases da digestão anaeróbia é possível obter gases como hidrogênio $\left(\mathrm{H}_{2}\right)$ na fase acidogênica, e metano $\left(\mathrm{CH}_{4}\right)$ na metanogênica, ambos com elevado conteúdo energético. Dessa forma, a separação de fases em digestão ácida e metanogênica tem sido explorada.

LIU et al. (2006) investigaram a produção de hidrogênio e metano a partir de resíduos sólidos domésticos, enquanto FERRAZ JR. (2013), VILELA (2016) e FUESS et al. (2017) utilizaram vinhaça e/ou melaço. Os autores citados obtiveram resultados promissores com a produção de hidrogênio e metano, contudo fatores como a estabilidade e longevidade dos reatores ainda requerem mais estudos. De acordo com BLONSKAJA; MENERT; VILU (2003) a separação de fases possibilita melhores condições para os dois principais estágios da digestão anaeróbia: acidogênese/fermentação e acetogênese/metanogênese, uma vez que o primeiro estágio ocorre muito mais rapidamente do que o segundo, devido ao menor tempo de crescimento dos microrganismos.

A eficiência da metanogênese depende de diversos fatores como nutrientes, fatores intrínsecos ao metabolismo dos microrganismos e ambientais. Os principais fatores ambientais para os processos anaeróbios são a temperatura (psicrofílicas, mesofílicas e termofilica), que auxilia na seleção de populações especificas e o $\mathrm{pH}$, apresentando a faixa ótima para eficiência da metanogênese entre 6,0 e 8,0. O melaço de cana-de-açúcar possui pH entre 4,0 e 6,0 (TURKDOGAN-AYDINOL; YETILMEZSOY, 2010), e em sistemas com separação de fases, a digestão ácida, que ocorre no primeiro reator, gera efluente com baixo $\mathrm{pH}$, que seguirá para o segundo reator (fase metanogênica). Assim para ocorrência da metanogênese em sistemas utilizando melaço como substrato, bem como em sistemas de duas fases, faz-se necessário a correção do $\mathrm{pH}$ por meio de químicos como hidróxido de sódio $(\mathrm{NaOH})$, ou bicarbonato de sódio $\left(\mathrm{NaHCO}_{3}\right)$. A adição de produtos para alcalinização do meio acarreta em maiores custos para o processo de tratamento, fomentando a busca por estratégias que permitam a adição de menores dosagens em sistemas já estabilizados.

Os reatores utilizados na presente pesquisa possuem como meio suporte para os microrganismos a espuma de poliuretano. A escolha desse material baseou-se nos resultados obtidos por VILELA (2016), que comparando reatores acidogênicos com espuma de poliuretano e polietileno de baixa densidade como material suporte, em condições termofílicas, verificou melhor rendimento de produção de $\mathrm{H}_{2}$ no reator com 
meio suporte de espuma de poliuretano. Nos reatores metanogênicos também foi utilizado o mesmo material suporte devido aos resultados positivos na produção de $\mathrm{CH}_{4}$ descritos por SILVA et al. (2011).

Os reatores de leito fixo estruturado apresentam excelente desempenho para resíduos com elevada carga orgânica (MENG et al., 2017). Além disso, o leito fixo em reatores anaeróbios é vantajoso para a produção de biogás, prescindindo da utilização de sistemas de separação de fases. Apresentam simplicidade de construção, eliminando a necessidade de equipamento de mistura. Garantem maiores tempos de retenção celular $(\theta c)$, menor geração de lodo, maior tolerância a cargas tóxicas e melhor recuperação após períodos sem alimentação. Apesar das vantagens apresentadas, os reatores de leito fixo apresentam como desvantagem a intolerância a grandes concentrações de sólidos, que podem colmatar o meio e tornar o volume útil menor devido ao meio suporte (RAJESHWARI et al., 2000). A distribuição espacial de comunidades microbiológicas específicas ao longo do comprimento do leito (LIN et al., 2012) também se apresentam como uma desvantagem, uma vez que reatores de leito fixo apresentam menos turbulência do que reatores de mistura completa, acarretando em uma maior resistência a transferência de massa (SHOW; LEE; CHANG, 2011), porém essa característica beneficia alguns processos bioquímicos.

Logo, o objetivo principal desse trabalho foi avaliar o potencial de produção de biogás em sistemas anaeróbios de duas fases comparando com sistema de fase única a partir do melaço de cana-de-açúcar. A diminuição da adição gradual do alcalinizante $\mathrm{NaHCO}_{3}$ também foi avaliada no reator de fase única. 


\section{OBJETIVOS}

\subsection{Objetivo geral}

O objetivo geral deste trabalho foi comparar o desempenho de sistema de reatores de leito fixo estruturado com espuma de poliuretano em um sistema de duas fases (reator acidogênico e reator metanogênico) e sistema de fase única para a produção de biogás, a partir do melaço, subproduto da cana-de-açúcar.

\subsection{Objetivos específicos}

- Avaliar a produção de hidrogênio em reator acidogênico em condições termofílicas $\left(55^{\circ} \mathrm{C}\right)$, sob baixos $\mathrm{TDH}$ e $\mathrm{pH}$;

- Avaliar o desempenho de reator metanogênico de sistema de duas fases para a produção de biogás (metano);

- Avaliar o desempenho de reator anaeróbio de fase única para a produção de biogás (metano);

- Comparar o desempenho dos sistemas de duas fases e fase única sob mesmas condições para a produção de biogás;

- Estudar o efeito da redução da adição de bicarbonato de sódio em sistema de fase única, com relação à produção de biogás a partir de matriz facilmente biodegradável, o melaço. 


\section{REVISÃO BIBLIOGRÁFICA}

A revisão bibliográfica apresentará uma abordagem sobre o crescimento da indústria sucroalcooleira no Brasil, com destaque para um dos resíduos da geração do açúcar, o melaço, e como esse subproduto pode ser utilizado pela digestão anaeróbia para a produção de biogás com base na literatura fundamental e na atual.

\subsection{A indústria sucroalcooleira}

A cana-de-açúcar é cultivada em mais de cem países, porém $75 \%$ da produção está concentrada em oito países, sendo o Brasil o maior produtor de cana-de açúcar, com mais de 666 milhões de toneladas distribuídas em 371 unidades produtoras na safra de 2015/2016. A região Centro-sul é responsável por 92\% dessa produção sendo que o Estado de São Paulo é o maior produtor, contribuindo com 60\% (UNICA, 2017).

A utilização da biomassa proveniente da cana-de-açúcar teve grande crescimento no Brasil em 1975 com o Programa Nacional do Álcool (Proálcool), o qual estimulou o crescimento do cultivo de cana, e consequentemente das usinas sucroalcooleiras em substituição ao petróleo, devido ao seu elevado preço da época. Atualmente, de acordo com a Agencia Nacional de Energia Elétrica (ANEEL) 8,9\% da matriz energética brasileira é proveniente dessa biomassa, e dentro desse panorama, apenas $0,0011 \%$ da energia é de biogás da agroindústria.

O processamento da cana-de-açúcar e a destilação geram impactos ao meio ambiente, pois além de consumir energia e água, produzem resíduos sólidos, líquidos e gasosos (VACCARI et al., 2005). A produção de açúcar e de álcool ocorre paralelamente, e a partir de 1 tonelada de cana pode-se produzir 50,8 $\mathrm{kg}$ de açúcar e 53,4 L de etanol, em que subprodutos como bagaço, caldo, torta de filtro, melaço e vinhaça são gerados (MORAES et al., 2014).

A indústria da cana-de-açúcar pode ser destinada à produção do álcool a partir do caldo (usinas autônomas) ou a partir do caldo e melaço (usinas anexas), sendo que na primeira o único produto final será o álcool, enquanto que nas usinas anexas são produzidos álcool e açúcar.

O fluxograma da Figura 3.1 é de uma usina anexa. As etapas iniciais são compostas pela colheita e moagem. Nessa primeira etapa, a cana é lavada, picada e encaminhada às 
moendas, tendo com subprodutos o caldo e o bagaço, sendo esse utilizado nas caldeiras para geração de eletricidade e energia térmica. A utilização do bagaço nas caldeiras é uma boa alternativa, pois diminui o passivo ambiental, além de gerar economia de energia. $\mathrm{O}$ caldo segue para a segunda etapa, sendo tratado por processos químicos (coagulação, floculação e sedimentação), e filtrado para retirar as impurezas, gerando a torta de filtro a qual é utilizada como complemento de adubação nas plantações. O caldo passa por processo de evaporação, cozimento, centrifugação e secagem, dando origem ao açúcar. Porém, a centrifugação gera um subproduto com elevado teor de sacarose, chamado melaço de cana-de-açúcar.

O melaço, nas usinas anexas, é utilizado para a produção do álcool. Nessa etapa, a mistura de melaço e caldo (denominado mosto) passa por processo de fermentação onde são acrescentados microrganismos fermentadores, como Saccharomyces cerevisae. A partir desse processo de fermentação é obtido o vinho, podendo conter até $12 \%$ do seu volume em álcool. O vinho é levado até colunas de destilação, obtendo como resíduo a vinhaça. O produto da destilação do vinho passa por retificação gerando o etanol hidratado, passando por um processo de desidratação e gerando o produto final: álcool anidro.

De acordo com a Companhia Nacional de Abastecimento (CONAB, 2013) 65\% das usinas de cana-de-açúcar são anexas, 29,5\% autônomas e apenas 5,5\% das unidades produzem apenas açúcar. Diante desse cenário e das etapas de produção de álcool e açúcar, observa-se que o melaço é o principal subproduto dessa indústria. Sua utilização vai além da produção de álcool, sendo utilizado para produção de rações, levedura para panificação e antibióticos (SILVA, 2008). Logo, o estudo da viabilidade da produção de biogás $\left(\mathrm{H}_{2}\right.$ e $\mathrm{CH}_{4}$ ) a partir do melaço de cana-de-açúcar em condições anaeróbias deve ser considerado como alternativa, com vista à recuperação de recursos e energia (MORAES et al., 2014).

O poder calorífico do biogás varia de acordo com a porcentagem de metano ou hidrogênio existente nele, sendo o poder calorífico do metano puro de $50 \mathrm{KJ} \mathrm{g}^{-1}$, e do hidrogênio de $122 \mathrm{KJ} \mathrm{g}^{-1}$, o que os tornam viáveis para utilização como fonte de energia. Assim, cresce no Brasil programas como o RenovaBio, lançado em 2016 que tem como objetivo estimular a produção de biocombustíveis (etanol, biodiesel, biogás e bioquerosene). 
Entre os biocombustíveis destaca-se a utilização do biometano que teve seu uso regulamentado pela Resolução ${ }^{\circ} 8$, de 30 de janeiro de 2015, da Agência Nacional do Petróleo, Gás Natural e biocombustíveis (ANP). Assim, esse biogás pode ter o mesmo uso do gás natural, bem como mesma valoração econômica.

Diante da oportunidade, a empresa do setor sucroenergético, Raízen, venceu o Leilão de energia nova A-5. O contrato terá início em 2021 com produção de 65 milhões de $\mathrm{m}^{3}$ de biogás e capacidade de 21 MW (FGV ENERGIA, 2017). Portanto, pesquisas para avaliação do potencial energético a partir de diferentes substratos são vantajosas diante do novo cenário energético que o país vem apresentando. 


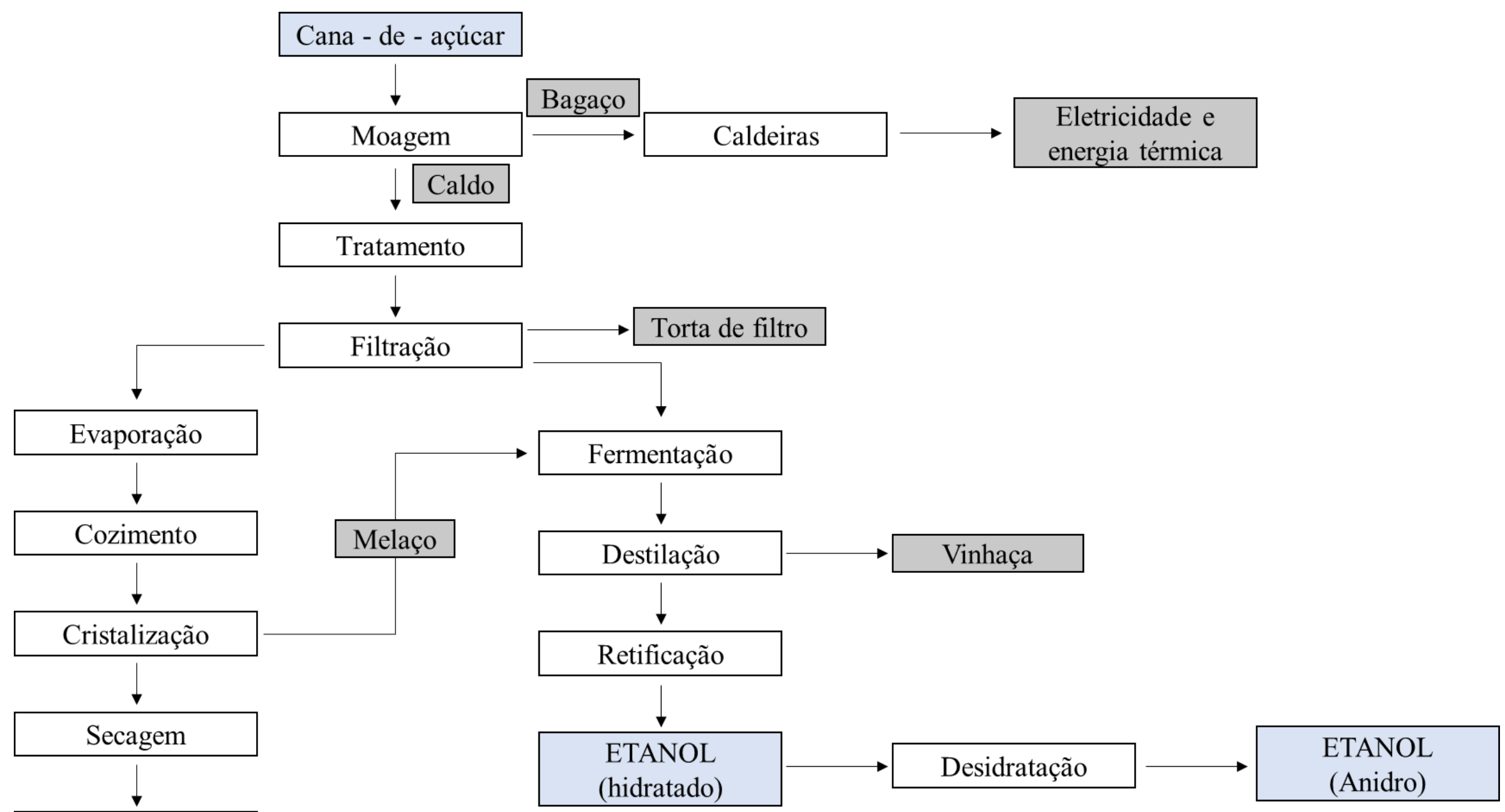

AÇÚCAR

Figura 3.1-Fluxograma simplificado das etapas de produção de álcool e açúcar a partir da cana-de-açúcar (adaptado de MORAES et al., 2015) 


\subsection{Processos anaeróbios termofílicos}

A digestão anaeróbia caracteriza-se por ser um processo auto-regulado no qual diferentes populações de microrganismos interagem na ausência de oxigênio para produção de metano $\left(\mathrm{CH}_{4}\right)$ e gás carbônico $\left(\mathrm{CO}_{2}\right)$ a partir da matéria orgânica (MOSEY, 1982). Esse processo é composto por quatro etapas principais: Hidrólise, acidogênese, acetogênese e metanogênese.

A hidrólise consiste na quebra de moléculas complexas (proteínas, lipídios e carboidratos) em moléculas mais simples (aminoácidos, ácidos graxos, açúcares) por meio de enzimas hidrolíticas para que possam penetrar na membrana celular dos microrganismos. Em seguida ocorre a acidogênese, em que os compostos hidrolisados são transformados em hidrogênio $\left(\mathrm{H}_{2}\right)$, gás carbônico $\left(\mathrm{CO}_{2}\right)$ e ácidos orgânicos voláteis, como por exemplo, ácido lático, ácido acético, ácido butírico, entre outros. A rota metabólica que o processo irá seguir depende de fatores ambientais e nutricionais que selecionam os organismos no sistema. A partir das principais rotas de transformação, cada sistema apresentará um determinado rendimento, uma vez que a concentração final de $\mathrm{H}_{2}$ depende da rota de acidificação (FERNANDES et al., 2010). A acetogênese ocorre posteriormente, produzindo $\mathrm{H}_{2}, \mathrm{CO}_{2}$ e acetato e é seguida pela metanogênese, em que as arqueias metanogênicas hidrogenotróficas transformam o $\mathrm{H}_{2}$ e $\mathrm{CO}_{2}$, e as arqueias metanogênicas acetoclásticas transformam o acetato em metano $\left(\mathrm{CH}_{4}\right)$ e gás carbônico $\left(\mathrm{CO}_{2}\right)$.

A digestão anaeróbia pode ocorrer em diferentes condições ambientais (temperatura e pH) e nutricionais (relação DQO: N: P, metais traços, aminoácidos e vitaminas). Em relação às condições ambientais há quatro faixas de temperaturas para a ocorrência da digestão anaeróbia: psicrofílicas $\left(<25^{\circ} \mathrm{C}\right)$; mesofílicas $\left(25-40^{\circ} \mathrm{C}\right)$; termofilicas $\left(50-55^{\circ} \mathrm{C}\right)$; e hipertermofílicas $\left(65-80^{\circ} \mathrm{C}\right)$.

No Brasil, devido as suas condições climáticas, as estações de tratamento de águas residuárias encontram-se em condições mesofílicas. A produção de biogás $\left(\mathrm{H}_{2}\right.$ e $\left.\mathrm{CH}_{4}\right)$ em condição termofílica apresenta vantagem, uma vez que haverá menor retenção de gás dissolvido no líquido, pois, a solubilidade de compostos gasosos decresce com a elevação da temperatura. De acordo com SOUZA et al. (1992) sistemas termofílicos suportam maiores cargas orgânicas quando comparado ao sistema mesofílico devido a maior velocidade de consumo do substrato dos organismos termófilos, o que permite seu 
estabelecimento e recuperação mais rápida. Logo, a maior velocidade de conversão desses organismos permite a aplicação de menores tempos de detenção hidráulica (TDH), o que viabiliza reatores menores na digestão termofílica (VLISSIDIS; ZOUBOULIS, 1993).

KIM et al. (2002) compararam diferentes configurações de sistemas de reatores anaeróbios de mistura completa (CSTR, CSTR de fase única e alimentado, CSTR de sistema combinado alimentado em batelada, e reator de única fase sem mistura) alimentados com ração de cães nas condições mesofílicas $\left(35^{\circ} \mathrm{C}\right)$ e termofílicas $\left(55^{\circ} \mathrm{C}\right)$. Durante a o desempenho estável, para o reator de fase única sem mistura, foi observado maior rendimento do reator termofílico para a produção de biogás e remoção de sólidos voláteis.

Em relação às usinas sucroalcooleiras, FERRAZ JR. (2013) avaliou a produção de $\mathrm{H}_{2}$ em sistemas a $25^{\circ} \mathrm{C}$ e a $55^{\circ} \mathrm{C}$ em reatores anaeróbio de leito empacotado com polietileno de baixa densidade, utilizando como substrato a vinhaça de cana-de-açúcar. Para TDH de 16, 12 e 8 horas não foi detectado produção de $\mathrm{H}_{2}$ em condições mesofílicas, enquanto que nos reatores termofílicos foi observada produção continua de $\mathrm{H}_{2}$, demonstrando a melhor eficiência de sistemas a $55^{\circ} \mathrm{C}$ para o substrato analisado.

A Tabela 3.1 apresenta uma comparação de produção de $\mathrm{H}_{2}$ nas condições mesofílicas, termofílicas e hipertermofílicas a partir de diferentes substratos, carga orgânica volumétrica (COV), TDH, pH, eficiência de conversão de carboidratos totais (\% $\mathrm{CHt})$, porcentagem de $\mathrm{H}_{2}$ no biogás $\left(\% \mathrm{H}_{2}\right)$ e produção volumétrica de $\mathrm{H}_{2}(\mathrm{PVH})$. Na Tabela 3.2 foi realizada uma comparação de produção de $\mathrm{CH}_{4}$ em condições mesofílicas e termofílicas a partir de substratos como a vinhaça de cana-de-açúcar e de beterraba, e melaço de cana-de-açúcar. Os parâmetros comparados foram COV, TDH, eficiência de remoção de matéria orgânica medida em DQO (\%DQO) e produção volumétrica de $\mathrm{CH}_{4}$ (PVM). 
Tabela 3.1 - Comparação do rendimento de $\mathrm{H} 2$ a partir de diferentes substratos e temperaturas

\begin{tabular}{|c|c|c|c|c|c|c|c|c|c|}
\hline Temperatura & $\begin{array}{c}\text { Configuração } \\
\text { do reator }\end{array}$ & Substrato & $\begin{array}{c}\text { COV } \\
\left(g^{-1} d^{-1}\right)\end{array}$ & TDH & pH & $\% \mathrm{CHt}$ & $\% \mathbf{H 2}$ & $\begin{array}{c}\text { PVH } \\
\left(\mathrm{mLH} 2 \mathrm{~L}^{-1} \mathbf{d}^{-1}\right)\end{array}$ & Referência \\
\hline \multirow{2}{*}{$\begin{array}{l}\text { Mesofílica } \\
\left(25-35^{\circ} \mathrm{C}\right)\end{array}$} & $\begin{array}{c}\text { IBRCS + } \\
\text { CSTR }\end{array}$ & Glicose & 6,5 & $8 \mathrm{~h}$ & 7,0 & $99 \%$ & $71 \%$ & 2400,0 & $\begin{array}{l}\text { HAFEZ et al. } \\
\text { (2010) }\end{array}$ \\
\hline & CSTR & Melaço & 68,2 & 4,2 & 6,5 & & $52 \%$ & 5250,0 & REN et al. (2006) \\
\hline \multirow{4}{*}{$\begin{array}{c}\text { Termofílica } \\
\qquad\left(5^{\circ} \mathbf{C}\right)\end{array}$} & UASB & $\begin{array}{l}\text { Melaço de } \\
\text { beterraba }\end{array}$ & 16,7 & $24 \mathrm{~h}$ & 7,3 & $86 \%$ & $54 \%$ & 4500,0 & $\begin{array}{l}\text { KONGJAN; O- } \\
\text { THONG; } \\
\text { ANGELIDAKI } \\
\text { (2011) }\end{array}$ \\
\hline & $\begin{array}{l}\text { APBR } \\
\text { CSTR }\end{array}$ & Sacarose & 12,0 & $\begin{array}{c}3 \mathrm{~h} \\
24 \mathrm{~h}\end{array}$ & 5,5 & $\begin{array}{l}50 \% \\
48 \%\end{array}$ & $\begin{array}{l}\text { ND } \\
\text { ND }\end{array}$ & $\begin{array}{r}2700,0 \\
500,0\end{array}$ & $\begin{array}{c}\text { KESKIN; GIUSTI; } \\
\text { AZBAR (2012) }\end{array}$ \\
\hline & APBR & Vinhaça de cana & 54,3 & $16 \mathrm{~h}$ & 5,1 & 79,4 & $30,6 \%$ & 331,4 & $\begin{array}{l}\text { FERRAZ JR. et al. } \\
\qquad(2014)\end{array}$ \\
\hline & APBR & Vinhaça de cana & 84,2 & $7,5 \mathrm{~h}$ & 5,4 & $81 \%$ & $46,2 \%$ & 2107,0 & $\begin{array}{l}\text { FUESS et al. } \\
\text { (2016) }\end{array}$ \\
\hline
\end{tabular}


Tabela 3.1 - Comparação do rendimento de $\mathrm{H}_{2}$ a partir de diferentes substratos e temperaturas (continuação)

\begin{tabular}{|c|c|c|c|c|c|c|c|c|c|}
\hline Temperatura & $\begin{array}{l}\text { Configuração } \\
\text { do reator }\end{array}$ & Substrato & $\begin{array}{c}\text { COV } \\
\left(\mathrm{g} \mathrm{L}^{-1} \mathbf{d}^{-1}\right)\end{array}$ & TDH & pH & $\% \mathbf{C H t}$ & $\% \mathbf{H}_{2}$ & $\begin{array}{c}\text { PVH } \\
\left(\mathbf{m L H} \mathbf{L}^{-1} \mathbf{d}^{-1}\right)\end{array}$ & Referência \\
\hline \multirow{3}{*}{$\begin{array}{c}\text { Termofílico } \\
\text { extremo } \\
\left(7^{\circ}\right)\end{array}$} & CSTR & \multirow{3}{*}{$\begin{array}{l}\text { Palha de } \\
\text { trigo } \\
\text { hidrolisada }\end{array}$} & 1,5 & 3 dias & 5,3 & $97,1 \%$ & $41,5 \%$ & 243,1 & \multirow{3}{*}{$\begin{array}{c}\text { KONGJAN; } \\
\text { ANGELIDAKI } \\
(2010)\end{array}$} \\
\hline & UASB & & 4,4 & $1 \mathrm{dia}$ & 5,1 & $98,1 \%$ & $43,2 \%$ & 821,4 & \\
\hline & $\mathrm{AF}$ & & 4,4 & $1 \mathrm{dia}$ & 5,4 & $94,3 \%$ & $32,6 \%$ & 493,5 & \\
\hline
\end{tabular}

*ND valor não disponível

*Reatores: IBRCS: Sistema integrado de clarificador de biohidrogênio (integrated biohydrogen reactor clarifier systems); CSTR: Reator anaeróbio de mistura completa (continuously stirred-tank reactor); UASB: reator anaeróbio de manta de lodo (Upflow anarobic sludged blanket); APBR: Reator anaeróbio de leito fixo ( anaerobic packed-bed reactor); AF: filtro anaeróbio (anaerobic filter). 
Tabela 3.2 - Comparação do rendimento de $\mathrm{CH}_{4}$ a partir de diferentes substratos e temperaturas

\begin{tabular}{|c|c|c|c|c|c|c|c|}
\hline Temperatura & $\begin{array}{c}\text { Configuração } \\
\text { do reator }\end{array}$ & Substrato & $\begin{array}{c}\text { COV } \\
\left(g^{-1} d^{-1}\right)\end{array}$ & TDH & \%DQO & $\begin{array}{c}\text { PVM } \\
\left(\mathrm{LCH}_{\mathbf{4}} \mathrm{L}^{-1} \mathbf{d}^{-1}\right)\end{array}$ & Referência \\
\hline \multirow{2}{*}{$\begin{array}{l}\text { Mesofílica } \\
\qquad\left(35^{\circ} \mathbf{C}\right)\end{array}$} & \multirow{2}{*}{ UASB } & $\begin{array}{l}\text { Vinhaça de } \\
\text { cana }\end{array}$ & $5-11$ & 2,8 dias & $81 \%$ & 0,325 & \multirow{2}{*}{$\begin{array}{c}\text { BARROS } \\
\text { (2013) }\end{array}$} \\
\hline & & $\begin{array}{l}\text { Melaço de } \\
\text { cana }\end{array}$ & $5-7$ & 2,8 dias & $36 \%$ & 0,322 & \\
\hline \multirow{5}{*}{$\begin{array}{c}\text { Termofílica } \\
\left(5^{\circ}{ }^{\circ} \mathbf{C}\right)\end{array}$} & UASB & $\begin{array}{l}\text { Vinhaça de } \\
\text { beterraba }\end{array}$ & 6 & 10 dias & $86 \%$ & 1,9 & $\begin{array}{c}\text { VLISSIDIS; } \\
\text { ZOUBOULIS } \\
\text { (1993) }\end{array}$ \\
\hline & ASTBR & $\begin{array}{l}\text { Melaço de } \\
\text { cana }\end{array}$ & $1-17,5$ & $\begin{array}{l}12-240 \\
\text { horas }\end{array}$ & $80 \%$ & 2,65 & $\begin{array}{l}\text { VILELA } \\
\text { (2016) }\end{array}$ \\
\hline & UASB & $\begin{array}{l}\text { Melaço de } \\
\text { cana }\end{array}$ & $9,4-16,9$ & 2-4 dias & $\mathrm{ND}^{*}$ & 3,38 & $\begin{array}{c}\text { KONGJAN et } \\
\text { al. (2013) }\end{array}$ \\
\hline & ASTBR & $\begin{array}{l}\text { Vinhaça de } \\
\text { cana }\end{array}$ & $15-30$ & $\begin{array}{l}37-18 \\
\text { horas }\end{array}$ & $83,5 \%$ & 4,5 & \multirow{2}{*}{$\begin{array}{c}\text { FUESS et al. } \\
\text { (2017) }\end{array}$} \\
\hline & UASB & $\begin{array}{c}\text { Vinhaça de } \\
\text { cana }\end{array}$ & $15-25$ & $\begin{array}{l}37-18 \\
\text { horas }\end{array}$ & $70,2 \%$ & 2,28 & \\
\hline
\end{tabular}

*Reatores: UASB: Reator anaeróbio de manta de lodo (Upflow anarobic sludged blanket); e ASTBR: Reator anaeróbio de leito estruturado (anaerobic structured-bed reactor) 


\subsection{Produção de biogás a partir do melaço}

O melaço é um resíduo da fabricação do açúcar e é encontrado na forma de líquido viscoso de cor escura. A cada 1 tonelada de cana processada, cerca de $50 \mathrm{~kg}$ de melaço são produzidos (MEZAROBA; MENEGUETTI; GTROFF, 2010). A principal utilização desse substrato ocorre nas usinas de produção de álcool, porém devido ao seu baixo valor agregado e alto valor nutricional pode ser destinado à produção de rações, levedura para panificação e antibióticos (SILVA, 2008).

De acordo com BARROS (2013), os principais componentes do melaço são água; carboidratos nas formas de glicose e frutose; aminoácidos; ácidos carboxílicos; proteínas; vitaminas e fenóis. A composição do melaço de cana-de-açúcar está associada com a espécie de cana, época do ano, clima, tipo de corte, e eficiência industrial (SILVA, 2008), por isso podem sofrer variações. Na Tabela 3.3 é apresentada a composição do melaço em concentração de $10 \mathrm{~g} \mathrm{~L}^{-1}$ adaptada de VILELA (2016).

Tabela 3.3 - Composição química do melaço de cana de açúcar

\begin{tabular}{|c|c|c|}
\hline Parâmetros & Unidades & Valores \\
\hline $\mathrm{pH}$ & Adimensional & 4,78 \\
\hline DQO Total & $\left(\mathrm{mg} . \mathrm{L}^{-1}\right)$ & 8.720 \\
\hline DQO solúvel $(0.45 \mu \mathrm{m})$ & $\left(\mathrm{mg} \cdot \mathrm{L}^{-1}\right)$ & 7.880 \\
\hline $\mathrm{DBO}_{5}$ & $\left(\mathrm{mg} \cdot \mathrm{L}^{-1}\right)$ & 3.992 \\
\hline Alcalinidade Total & $\left(\mathrm{mg} \mathrm{CaCO}_{3} \cdot \mathrm{L}^{-1}\right)$ & 37 \\
\hline N. Amoniacal & $\left(\mathrm{mg}\right.$ N.L $\left.{ }^{-1}\right)$ & 67 \\
\hline N. total Kjeldahl & $\left(\mathrm{mg} \mathrm{N} . \mathrm{L}^{-1}\right)$ & 269 \\
\hline Nitrato & $\left(\mathrm{mg} \mathrm{N}-\mathrm{NO}_{3}^{-} \cdot \mathrm{L}^{-1}\right)$ & 295 \\
\hline Nitrito & $\left(\mathrm{mg} \mathrm{N}-\mathrm{NO}_{2}^{-} \cdot \mathrm{L}^{-1}\right)$ & 0,10 \\
\hline Sulfato & $\left(\mathrm{mg} \mathrm{SO}_{4}{ }^{2-} \cdot \mathrm{L}^{-1}\right)$ & 70 \\
\hline Sulfeto & $\left(\mathrm{mg} \mathrm{S} \mathrm{S}^{2-} \cdot \mathrm{L}^{-1}\right)$ & 0,190 \\
\hline Fenol & $\left(\mathrm{mg} \mathrm{C}_{6} \mathrm{H}_{5} \mathrm{OH} . \mathrm{L}^{-1}\right)$ & 0,082 \\
\hline \multicolumn{3}{|c|}{ Série Metais } \\
\hline Zinco & $\left(\mathrm{mg} \mathrm{Zn} \cdot \mathrm{L}^{-1}\right)$ & 0,168 \\
\hline Chumbo & $\left(\mathrm{mg} \mathrm{Pb} \cdot \mathrm{L}^{-1}\right)$ & 0,06 \\
\hline Cádmio & $\left(\mathrm{mg} \mathrm{Cd} . \mathrm{L}^{-1}\right)$ & 0,055 \\
\hline Níquel & $\left(\mathrm{mg} \mathrm{Ni} \cdot \mathrm{L}^{-1}\right)$ & 0,576 \\
\hline Ferro & $\left(\mathrm{mg} \mathrm{Fe} . \mathrm{L}^{-1}\right)$ & 0,838 \\
\hline Manganês & $\left(\mathrm{mg} \mathrm{Mn} \cdot \mathrm{L}^{-1}\right)$ & 0,270 \\
\hline Cobre & $\left(\mathrm{mg} \mathrm{Cu} . \mathrm{L}^{-1}\right)$ & 0,053 \\
\hline Cromo Total & $\left(\mathrm{mg} \mathrm{Cr} \cdot \mathrm{L}^{-1}\right)$ & 0,044 \\
\hline Cálcio & $\left(\mathrm{mg} \mathrm{Ca} . \mathrm{L}^{-1}\right)$ & 287,00 \\
\hline
\end{tabular}


Tabela 3.3 - Composição química do melaço de cana de açúcar (continuação)

\begin{tabular}{|c|c|c|}
\hline $\begin{array}{l}\text { Magnésio } \\
\text { Sódio } \\
\text { Potássio }\end{array}$ & $\begin{array}{c}\left(\mathrm{mg} \mathrm{Mg} . \mathrm{L}^{-1}\right) \\
\left(\mathrm{mg} \mathrm{Na} \cdot \mathrm{L}^{-1}\right) \\
\left(\mathrm{mg} \mathrm{K} \cdot \mathrm{L}^{-1}\right)\end{array}$ & $\begin{array}{c}21,18 \\
4,70 \\
216\end{array}$ \\
\hline \multicolumn{3}{|c|}{ Carboidratos } \\
\hline Glicose & $\left(\mathrm{mg} \cdot \mathrm{L}^{-1}\right)$ & $2.443,30$ \\
\hline Frutose & $\left(\mathrm{mg} \cdot \mathrm{L}^{-1}\right)$ & 845,50 \\
\hline \multicolumn{3}{|c|}{ Ácidos Orgânicos Voláteis } \\
\hline Cítrico & $\left(\mathrm{mg} . \mathrm{L}^{-1}\right)$ & $1.584,05$ \\
\hline Lático & $\left(\mathrm{mg} \cdot \mathrm{L}^{-1}\right)$ & N/D \\
\hline Fórmico & $\left(\mathrm{mg} \cdot \mathrm{L}^{-1}\right)$ & N/D \\
\hline Acético & $\left(\mathrm{mg} . \mathrm{L}^{-1}\right)$ & N/D \\
\hline Propiônico & $\left(\mathrm{mg} \cdot \mathrm{L}^{-1}\right)$ & N/D \\
\hline Butírico & $\left(\mathrm{mg} \cdot \mathrm{L}^{-1}\right)$ & N/D \\
\hline Valérico & $\left(\mathrm{mg} \cdot \mathrm{L}^{-1}\right)$ & 175,45 \\
\hline \multicolumn{3}{|c|}{ Série de Sólidos } \\
\hline Sólidos Totais & $\left(\mathrm{mg} \cdot \mathrm{L}^{-1}\right)$ & 7.651 \\
\hline Sólidos Totais Fixos & $\left(\mathrm{mg} \cdot \mathrm{L}^{-1}\right)$ & 521 \\
\hline Sólidos Totais Voláteis & $\left(\mathrm{mg} \cdot \mathrm{L}^{-1}\right)$ & 7.130 \\
\hline Sólidos Suspensos Totais & $\left(\mathrm{mg} \cdot \mathrm{L}^{-1}\right)$ & 197 \\
\hline Sólidos Suspensos Fixos & $\left(\mathrm{mg} \cdot \mathrm{L}^{-1}\right)$ & 27 \\
\hline Sólidos Suspensos Voláteis & $\left(\mathrm{mg} \cdot \mathrm{L}^{-1}\right)$ & 170 \\
\hline Sólidos Dissolvidos Totais & $\left(\mathrm{mg} \cdot \mathrm{L}^{-1}\right)$ & 7.454 \\
\hline Sólidos Dissolvidos Fixos & $\left(\mathrm{mg} \cdot \mathrm{L}^{-1}\right)$ & 494 \\
\hline Sólidos Dissolvidos Voláteis & $\left(\mathrm{mg} \cdot \mathrm{L}^{-1}\right)$ & 6.960 \\
\hline
\end{tabular}

Fonte: Adpatado de VILELA (2016).

A utilização do melaço na produção de biogás a partir da digestão anaeróbia é conveniente devido às suas condições nutricionais, as quais favorecem o crescimento de microrganismos por causa da alta quantidade de carbono e energia, porém, é necessário complementá-lo com nitrogênio, fósforo e magnésio (FELTRIN et al., 2000). Além de produzir energia limpa e renovável, o melaço pode ser associado a outras águas residuárias em usinas de processamento de álcool e açúcar para a produção de energia, como a vinhaça, na co-digestão, ou misturados com outros tipos de águas residuárias como a de bovinos e suínos, aumentando o seu potencial de produção de hidrogênio e metano (FANG; BOE; ANGELIDAKI, 2011; WU; LIN; ZHU, 2013). O melaço também foi avaliado como alternativa na substituição da vinhaça no período de entressafra. Entretanto, de acordo com BARBOSA, 2017 o retorno da alimentação com vinhaça após um período utilizando melaço de cana-de-açúcar como substrato em reatores UASB gerou maior instabilidade do sistema, quando comparada a um período da entressafra que os reatores ficaram sem alimentação. Essa maior instabilidade deve-se principalmente a mudanças nas 
comunidades microbiológicas, uma vez que o melaço apresenta menor complexidade de matéria orgânica em relação a vinhaça.

De acordo com REN et al. (2006), as bactérias fermentativas necessitam de substratos ricos em glicose ou sacarose para obter energia para o crescimento, manutenção celular, e gerar produtos intermediários, como álcool e ácidos. Desse modo, o melaço vem sendo estudado com fonte de energia para esses microrganismos, que acabam gerando subprodutos para as indústrias, trazendo além da diminuição dos resíduos, gases com valor econômico.

Um reator de chicanas com volume efetivo de 27,48 L, dividido em três compartimentos foi operado por LI et al. (2007) durante 26 dias para a produção de hidrogênio a partir do melaço da beterraba. $\mathrm{O}$ reator foi mantido em $35^{\circ} \mathrm{C}$, com DQO de $5000 \mathrm{mg} \mathrm{L}^{-1}$, pH efluente entre 4,3 e 4,4 e alcalinidade entre $306-334 \mathrm{mg} \mathrm{CaCO}_{3} \mathrm{~L}^{-1}$. A produção de hidrogênio para esse reator foi de $32,5 \mathrm{~L} \mathrm{~d}^{-1}$ e uma taxa de conversão de substrato de $0,16 \mathrm{~L} \mathrm{gDQO}^{-1}$.

Melaço, gerado como subproduto da indústria de glutamato de sódio, foi utilizado para avaliar a comunidade microbiana em TDH de 12, 8, 6, 4 e 3 horas (CHANG et al., 2008). Foi obtido que em menores TDH a produção volumétrica de $\mathrm{H}_{2}$ (PVH) foi maior, porém o rendimento de $\mathrm{HY}$ em termos de mol $\mathrm{H}_{2}$ mol $_{\text {hexose }}{ }^{-1}$ foi menor. Com um TDH de 12 horas o HY foi de 2,1 mol $\mathrm{H}_{2}$ molhexose $^{-1}$ e PVH foi de 152,5 mmol $\mathrm{H}_{2} \mathrm{~L}^{-1} \mathrm{~d}^{-1}$. Para TDH de 3 horas os valores encontrados para HY e PVH foram 0,9 mol $\mathrm{H}_{2}$ mol $_{\text {hexose }}{ }^{-1}$ e 390,2 mmolH $2 \mathrm{~L}^{-1} \mathrm{~d}^{-1}$, respectivamente.

PARK et al. (2010) analisaram a produção de biogás em reatores de duas fases com melaço de cana-de-açúcar como substrato. Os reatores foram operados em condições mesofílicas $\left(35^{\circ} \mathrm{C}\right)$, com $\mathrm{pH}$ afluente ao reator acidogênico de 5,5 e DQO de $28 \mathrm{~g} \mathrm{~L}^{-1}$. O pH do afluente do reator metanogênico (efluente do reator acidogênico) era corrigido para 7,0 com solução de $\mathrm{NaOH}$. A partir dos reatores de duas fases foi possível obter produção máxima de hidrogênio de 2,80 $\mathrm{LH}_{2} \mathrm{~L}^{-1} \mathrm{~d}^{-1}$ com TDH de 6 horas, enquanto que o reator metanogênico foi operado com TDH de 6 dias, atingindo produção máxima de metano de $1,95 \mathrm{LCH}_{4} \mathrm{~L}^{-1} \mathrm{~d}^{-1}$.

Assim, o melaço, seja de cana-de-açúcar, beterraba, e de diversas outras origens, é um substrato viável para ser utilizado na digestão anaeróbia para geração de biogás. 


\subsection{Produção de biogás em sistemas de duas fases}

Em reatores de duas fases o processo de digestão anaeróbia ocorre separadamente em fase acidogênica e metanogênica, sendo necessário fornecer condições especiais para o crescimento predominante dos microrganismos desejados, tendo em vista que apresentam taxas de crescimento diferentes. Os organismos acidogênicos levam de 2-3 horas para crescerem, e os metanogênicos necessitam de 2-3 dias em temperatura mesofílica $\left(35^{\circ} \mathrm{C}\right)$ (MOSEY, 1982).

HARPER; POHLAND (1986) relataram que a separação de fases melhorou a qualidade do gás do reator de segunda fase (metanogênico), e destacaram que essa configuração de reator é indicada para águas residuárias com elevado potencial de acúmulo de ácido orgânicos. Assim, o melaço, por possuir elevada quantidade de carboidratos é facilmente degradado e gera grande quantidade de ácidos, sendo sistema de duas fases adequado a sua degradação.

Ao separar as fases é necessário observar que os carboidratos serão convertidos em ácidos, álcool, acetato, $\mathrm{H}_{2}, \mathrm{CO}_{2}$ na fase acidogênica, enquanto que a maior degradação da matéria orgânica ocorrerá apenas no reator de segunda fase. Assim, os produtos formados no reator de primeira fase serão transformados em $\mathrm{CH}_{4}$ e $\mathrm{CO}_{2}$ no reator de segunda fase, pontuando que o desempenho do reator de segunda fase depende do desempenho do primeiro reator (UENO; FUKUI; GOTO, 2007).

CHENG et al. (2016) estudaram reatores de mistura em duas fases para produção biológica de $\mathrm{H}_{2}$ e $\mathrm{CH}_{4}$ a partir do resíduos do bagaço de cana-de-açúcar e encontraram conversão de carboidratos próxima a 90\% para o reator acidogênico, e produção de 8,24 $\mathrm{mLH}_{2} \mathrm{gDQO}^{-1}$. A remoção de DQO total para os dois reatores foi de $81 \%$, entre os quais $0,3 \%$ foram convertidos em $\mathrm{H}_{2}$ e $72,8 \%$ em $\mathrm{CH}_{4}$.

KONGJAN et al. (2013) avaliaram a produção de $\mathrm{H}_{2}$ e $\mathrm{CH}_{4}$ a partir do melaço de beterraba em um processo anaeróbio termofílico $\left(55^{\circ} \mathrm{C}\right)$ em reatores de duas fases utilizando reatores UASB sequenciais, obtendo taxa máxima de produção de hidrogênio de $5600 \mathrm{~mL} \mathrm{H} \mathrm{H}_{2}^{-1} \mathrm{~L}^{-1}$, correspondendo a produção de $132 \mathrm{~mL} \mathrm{H}_{2} \mathrm{~g} \mathrm{SV}^{-1}$. O reator metanogênico produziu $3380 \mathrm{mLCH}_{4} \mathrm{~d}^{-1} \mathrm{~L}^{-1}$, o que equivale a $239 \mathrm{mLCH}_{4} \mathrm{gSV}^{-1}$, demonstrando a viabilidade de produção de biogás a partir do melaço. 
LEE et al. (2015) investigaram a produção de biogás em reatores de duas fases pela co-digestão do melaço e lodo de esgotos, utilizando uma razão de 2:1 (v/v) obtida por experimentos em batelada. Um reator CSTR com decantador foi utilizado anteriormente para separação do sólido e liquido, a partir do efluente desse reator é que o acidogênico era alimentado. $\mathrm{O}$ sistema acidogênico operado a temperatura de $35^{\circ} \mathrm{C}$ foi submetido à carga orgânica média de 12,5 gDQO L ${ }^{-1}$, pH 4,0 e TDH que foi reduzido de 42 horas para 21 horas, o que fez com que a produção de hidrogênio aumentasse de 0,05 para $0,35 \mathrm{LH}_{2} \mathrm{dia}^{-1}$. O reator metanogênico foi operado com pH de 7-8 e TDH de 84 até 56 horas, sendo o TDH de 84 horas, com carga de 2,45 gDQO L L $^{-1} \mathrm{da}^{-1}$ a melhor condição para esse sistema. A queda no TDH resultou em queda na produção de metano de $1,23 \mathrm{LCH}_{4} \mathrm{dia}^{-1}$ para 0,8 $\mathrm{LCH}_{4} \mathrm{dia}^{-1}$.

WU et al. (2016) avaliaram a influência das condições termofílicas e mesofílicas em reatores de sistema combinado e sistema único, alimentados com resíduos de lodo ativado. Os autores concluíram que nos reatores do sistema de duas fases houve maior remoção de sólidos totais e voláteis quando comparado ao sistema único. Entretanto, ressalta-se que o tipo de substrato influência na eficiência do sistema de duas fases, e consequentemente na produção de $\mathrm{H}_{2}$ e $\mathrm{CH}_{4}$ (GIORDANO; CANTÙ; SPAGNI, 2011). Um sistema de duas fases em condições termofílicas utilizando como substrato efluente da produção de amido obteve um rendimento total de energia de $13363 \mathrm{~kJ} \mathrm{~kg}^{-1} \mathrm{DQO}$, correspondendo a soma da produção de 81,5 $\mathrm{LH}_{2} \quad \mathrm{~kg}^{-1} \mathrm{DQO}$ proveniente do reator acidogênico, e 310,5 $\mathrm{LCH}_{4} \mathrm{~kg}^{-1} \mathrm{DQO}$ do reator metanogênico (KHONGKLIANG; KONGJAN; O-THONG, 2015).

Um dos problemas encontrados nos reatores do sistemas acidogênicos é a manutenção da produção de hidrogênio, pois após longos períodos de operação os reatores vão perdendo sua eficiência devido ao acúmulo de biomassa (HAFEZ et al., 2010), reduzindo a carga aplicada ao lodo. A partir dessa constatação, FUESS et al. (2016) avaliaram as estratégias operacionais em um reator acidogênico de leito fixo empacotado utilizando como substrato a vinhaça de cana-de-açúcar durante 240 dias, e observaram que a partir de $50^{\circ}$ dia ocorreu decaimento na produção de hidrogênio, por isso estratégias como aumento contínuo da carga orgânica, controle do pH efluente entre 5,1 e 5,2 e descarga periódica de biomassa foram essenciais para uma produção estável de biogás nos reatores acidogênicos. 
A partir do apresentado, constata-se que o sistema de duas fases vem se mostrando eficiente para a produção de biogás a partir de determinadas águas residuárias, além de proporcionar melhor estabilidade aos microrganismos e melhor controle do sistema (DEMIREL; YENIGÜN, 2002), desde que operados segundo estratégias adequadas.

\subsection{Produção de metano em reator de fase única}

Os reatores anaeróbios em sistema único são os mais comuns de serem encontrados, neles, todas as etapas da digestão anaeróbia ocorrem na mesma unidade, a partir do equilíbrio entre as populações participantes. As arqueias metanogênicas hidrogenotróficas desempenham papel importante na manutenção da baixa pressão parcial de $\mathrm{H}_{2}$ no sistema, o que garante a acetogênese. Deve- se atentar para a carga orgânica aplicada nesses sistemas, para que a estabilidade do sistema seja mantida.

Em reatores de fase única, os principais constituintes do biogás são $\mathrm{CH}_{4}, \mathrm{CO}_{2} \mathrm{e} \mathrm{H}_{2}$, podendo haver outros gases em menores concentrações conforme Tabela 3.4.

Tabela 3.4 - Composição do biogás. Fonte: adaptado de CASSINI (2003).

\begin{tabular}{cc}
\hline Composto & \% na mistura \\
\hline Metano & $50-75 \%$ \\
Dióxido de carbono & $25-40 \%$ \\
Hidrogênio & $1-3 \%$ \\
Oxigênio & $0,1-1 \%$ \\
Sulfeto de hidrogênio & $0,1-0,5 \%$ \\
Monóxido de carbono & 0 a $0,1 \%$ \\
\hline
\end{tabular}

Há diversos estudos comparando sistemas de duas fases e fase única como o de NASR et al. (2012), em que os reatores foram comparados na produção de biogás a partir da vinhaça com DQOt de $122 \mathrm{~g} \mathrm{~L}^{-1}$ em temperatura de $37^{\circ} \mathrm{C}$. Uma proporção inicial de

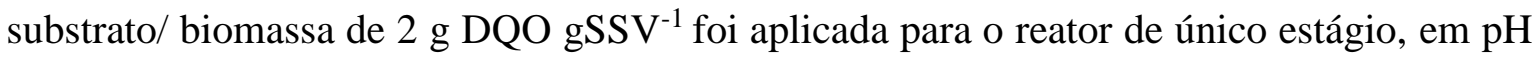
de 7,17, enquanto que para o reator de dois estágios a razão substrato/biomassa sofreu variação entre $2-8 \mathrm{~g}$ DQO gSSV${ }^{-1}$. Para o reator acidogênico foi adicionado $5 \mathrm{~g} \mathrm{~L}^{-1} \mathrm{de}$ $\mathrm{NaHCO}_{3}$, obtendo um $\mathrm{pH}$ entre 5,47 -5,5, e para o reator metanogênico foi adicionado $12 \mathrm{~g}$ $\mathrm{L}^{-1}$ de $\mathrm{NaHCO}_{3}$, sendo o $\mathrm{pH}$ de 7,16 -7,18. O ensaio foi conduzido em batelada, com 
volume de $250 \mathrm{~mL}$. Foi obtido rendimento de metano de $0,33 \mathrm{LCH}_{4} \mathrm{gDQO}_{\text {adicionada }^{-1}}$ para o reator de duas fases, enquanto que para o de fase única foi encontrado um rendimento de

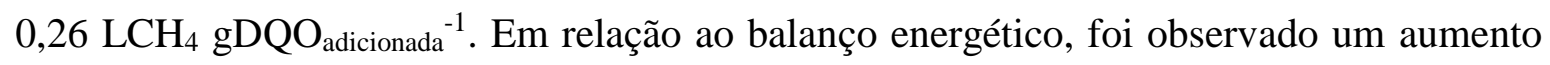
de $18,5 \%$ no rendimento energético no sistema de duas fases, quando comparado com o de única fase.

PISUTPAISAL et al. (2014) analisaram um reator de mistura completa (CSTR) com volume de $5 \mathrm{~L}$ para a produção de $\mathrm{CH}_{4}$ e $\mathrm{H}_{2}$ em reatores de duas fases a partir de resíduos de alimentos, sendo que o reator acidogênico foi operado com TDH de 12 horas e carga orgânica de 48 gDQO L-1 $\mathrm{d}^{-1}$ e o metanogênico de 24 horas, com carga de 24 gDQO $\mathrm{L}^{-1} \mathrm{~d}^{-1}$. Os resultados para a produção de $\mathrm{H}_{2}$ e $\mathrm{CH}_{4}$ foram de 292,7 e 391,6 $\mathrm{mL}_{\mathrm{gSV}^{-1}}$, respectivamente. Os autores concluíram que a energia recuperada do processo de dois estágios foi maior do que a de um único estágio, sendo, respectivamente de $6,5.10^{-2} \mathrm{~kW}-\mathrm{h}$ e 4,7. $10^{-2} \mathrm{~kW}-\mathrm{h}$, isso porque a energia proveniente dos reatores de duas fases foi estimada com base na produção de $\mathrm{H}_{2}$ e $\mathrm{CH}_{4}$, enquanto que de uma única fase resulta apenas do $\mathrm{CH}_{4}$.

De acordo com RAPPORT, et al. (2008), por mais que os reatores de única fase apresentem menor rendimento quando comparados ao de duas fases, a complexidade de operação, funcionamento, e despesas geradas pela separação de fases faz com que o uso de reatores únicos ainda se destaquem.

\subsection{Principais rotas metabólicas para produção de $\mathbf{H}_{2}$}

A produção de $\mathrm{H}_{2}$ por microrganismos depende de diferentes parâmetros impostos ao sistema, como: inóculo, substrato, $\mathrm{TDH}, \mathrm{COV}, \mathrm{pH}$, configuração do reator (MARIAKAKIS et al., 2012). Assim, cada sistema apresenta uma rota metabólica principal para a degradação do substrato, apresentando uma determinada PVH e HY.

Substratos ricos em carboidratos, como o melaço de cana-de-açúcar, são adequados para a produção de $\mathrm{H}_{2}$ (HAWKES et al., 2002; UENO et al., 2007) uma vez que são facilmente fermentados em moléculas menores de ácidos orgânicos que também podem ser convertidos em $\mathrm{H}_{2}$. A produção de hidrogênio pode ocorrer segundo as equações de conversão da glicose em ácido acético - HAc (Reação 1), ácido butírico - HBu (Reação 2), ácido propiônico - HPr (Reação 3) e ácido lático - HLc (Reação 4) (SAADY, 2013). A Reação 1 é a que apresenta maior rendimento de $\mathrm{H}_{2}, 4$ mols de $\mathrm{H}_{2}$ são gerados a partir de 
um mol de glicose. A reação 1 é seguida pela Reação 2 em termos de produção de $\mathrm{H}_{2}$, enquanto a reação de conversão de glicose em ácido propiônico (Reação 3) apresenta consumo de $\mathrm{H}_{2}$, não positiva para o rendimento global de $\mathrm{H}_{2}$. Na conversão de glicose em ácido lático (Reação 4) não há geração de $\mathrm{H}_{2}$, o qual será formado quando o lactato for convertido em acetato (Reação 5) na acetogênese.

\begin{tabular}{clcc} 
& \multicolumn{2}{c}{ Reações acidogênicas } & $\Delta \mathrm{G}(\mathrm{kJ})$ \\
Acetato & $\mathrm{C}_{6} \mathrm{H}_{12} \mathrm{O}_{6}+2 \mathrm{H}_{2} \mathrm{O} \longrightarrow 2 \mathrm{CH}_{3} \mathrm{COOH}+2 \mathrm{CO}_{2}+4 \mathrm{H}_{2}$ & $-206,00$ & (Reação 1) \\
Butirato & $\mathrm{C}_{6} \mathrm{H}_{12} \mathrm{O}_{6} \longrightarrow \mathrm{CH}_{3} \mathrm{CH}_{2} \mathrm{CH}_{2} \mathrm{COOH}+2 \mathrm{CO}_{2}+2 \mathrm{H}_{2}$ & $-254,00$ & (Reação 2) \\
Propionato & $\mathrm{C}_{6} \mathrm{H}_{12} \mathrm{O}_{6}+2 \mathrm{H}_{2} \longrightarrow 2 \mathrm{CH}_{3} \mathrm{CH}_{2} \mathrm{COOH}+2 \mathrm{H}_{2} \mathrm{O}$ & $-279,40$ & (Reação 3) \\
Lactato & $\mathrm{C}_{6} \mathrm{H}_{12} \mathrm{O}_{6} \longrightarrow 2 \mathrm{CH}_{3} \mathrm{CH}(\mathrm{OH}) \mathrm{COOH}$ & $-225,40$ & (Reação 4) \\
& Reação acetogênica & & \\
Lactato & $2 \mathrm{CH}_{3} \mathrm{CH}(\mathrm{OH}) \mathrm{COOH}+2 \mathrm{H}_{2} \mathrm{O} \rightarrow \mathrm{CH}_{3} \mathrm{COOH}+\mathrm{HCO}_{3}{ }^{-}+2 \mathrm{H}_{2}$ & $-4,2$ & (Reação 5)
\end{tabular}

Entre os microrganismos produtores de $\mathrm{H}_{2}$, merecem destaque as bactérias do gênero Clostridium (HALLENBECK; BENEMANN, 2002; MATSUMOTO; NISHIMURA, 2007; CHANG et al., 2008; FERRAZ JR. et al., 2014). Esse microrganismo é uma bactéria gram-positiva capaz de formar esporos, tornando-os mais resistentes a variações no sistema, como por exemplo, condições extremas de pH (WIEGEL et al., 2006; KIM et al., 2012; FERRAZ JR. et al., 2015), calor e desidratação (MARIAKAKIS et al., 2012).

Bactérias do gênero Clostridium diolis utilizaram as rotas dos ácidos acético e lático para a produção de $\mathrm{H}_{2}$, de forma que quando as concentrações desses ácidos diminuíram, iniciou-se a formação de $\mathrm{H}_{2}$ e $\mathrm{CO}_{2}$ (MATSUMOTO; NISHIMURA, 2007). Outros microrganismos encontrados em sistema termofílicos são os Lactobacillus, os quais competem por substrato com os demais microrganismos para a produção de $\mathrm{H}_{2}$ (HUNG et al., 2011).

WU et al. (2012) utilizaram um reator do tipo mistura completa (CSTR) alimentado com solução de lactato e acetato com $\mathrm{COV}$ de 55,64 $\mathrm{kg}$ DQO m $\mathrm{m}^{-3} \mathrm{dia}^{-1}$. Os autores observaram a formação de butirato e de $\mathrm{H}_{2}$ no sistema. Entretanto, quando o lactato do meio se esgotou, o crescimento da biomassa, a formação de butirato e $\mathrm{H}_{2}$ também cessaram. Demostrando que o gênero Clostridium encontrado no sistema utilizava principalmente o lactato como substrato. 
A utilização do lático e acético para a produção de $\mathrm{H}_{2}$ e butirato por microrganismos do gênero Clostridium foi relatada em reatores em batelada por DIEZGONZALEZ et al. (1995). Recentemente essa rota metabólica também foi avaliada em reatores contínuos anaeróbios de mistura completa (KIM et al., 2012; WU et al., 2012) e reator anaeróbio de leito fixo (FUESS et al., 2018). A reação do ácido butírico, $\mathrm{CO}_{2}$ e $\mathrm{H}_{2}$ sendo formados a partir do ácido lático e acético é representada pela Reação 6.

$\mathrm{CH}_{3} \mathrm{COOH}+2 \mathrm{CH}_{3} \mathrm{CH}(\mathrm{OH}) \mathrm{COOH} \rightarrow 1,5 \mathrm{CH}_{3} \mathrm{CH}_{2} \mathrm{CH}_{2} \mathrm{COOH}+\mathrm{H}_{2}+2 \mathrm{CO}_{2}$ (Reação 6)

Além dos microrganismos dos gêneros Clostridium e Lactobacilus outros organismos foram associados pela literatura para a produção de $\mathrm{H}_{2}$. FUESS et al. (2018) observaram bactérias do gênero Thermoanaerobacterium em reator de leito fixo utilizando como substrato a vinhaça de cana-de-açúcar. Os autores citados notaram que o ácido lático estava relacionado aos gêneros Lactobacillus (21,3-24,8\%) e Leuconostoc (0,6-3,0\%).

O gênero Thermoanaerobacterium é o maior responsável pela produção de $\mathrm{H}_{2} \mathrm{em}$ sistemas acidogênico alimentados com subprodutos da indústria sucroalcooleira (MARIAKAKIS et al., 2012; FERRAZ JR. et al., 2014, 2015; FUESS et al., 2018). Ressaltando que os gêneros Clostridium e Lactobacilus também são de extrema importância para a produção de $\mathrm{H}_{2}$ nesses sistemas.

\subsection{Efeito do pH na produção de $\mathbf{H}_{2}$}

O pH é um parâmetro de grande importância para sistemas biológicos de tratamento pois auxilia na seleção dos microrganismos do meio. Sendo assim, em sistemas acidogênicos, para determinado $\mathrm{pH}$, substrato e temperatura haverá a predominância de gêneros específicos de microrganismos (HORIUCHI et al., 2002), e consequentemente rotas metabólicas diferentes.

Geralmente, a produção biológica de $\mathrm{H}_{2}$ é possível entre pH 4,5 e 7,0 (KIM et al., 2012), mas a faixa ideal para sistemas acidogênicos foi relatada entre 5,0 e 6,0 (WANG; WAN, 2009). Em sistemas acidogênicos produzindo $\mathrm{H}_{2}$ a partir da vinhaça de cana-deaçúcar o pH ideal encontrado variou entre 5,0 e 5,3 (FERRAZ JR et al., 2014; FUESS et al., 2016), e para sistema acidogênico utilizando como substrato o melaço de cana-deaçúcar foi possivel obter produção de $\mathrm{H}_{2} \mathrm{em}$ pH de 4,10 (VILELA, 2017). Foi verificado que baixos valores de $\mathrm{pH}$ afluentes possibilitam maior potencial de produção de $\mathrm{H}_{2}$ mas 
com uma baixa velocidade (ALBANEZ, 2015). KHANAL et al. (2004) a partir de efluente sintético de sacarose encontraram as maiores produções de $\mathrm{H}_{2}$ em $\mathrm{pH}$ de 4,5.

MATSUMOTO; NISHIMURA (2007) avaliaram a produção de $\mathrm{H}_{2}$ a partir de uma solução de ácido acético e lático utilizando lodo de pós-destilação da batata doce em reatores em batelada. Os autores encontraram a faixa ideal de $\mathrm{pH}$ entre 5,8 e 7,4, sendo a variação da produção entre 4,8 e 5,86 $\mathrm{mL}$ de $\mathrm{H}_{2}$ para cada $5 \mathrm{~mL}$ de solução de lodo. A máxima produção foi obtida com $\mathrm{pH}$ de 6,8 e não houve produção de $\mathrm{H}_{2} \mathrm{em}$ pH abaixo de 5,1 e acima de 7,7 .

KIM et al. (2012) utilizaram reatores em batelada e CSTR para avaliar o efeito do lactato na produção de $\mathrm{H}_{2}$ em $\mathrm{pH} 4,5$. $\mathrm{O}$ reator operou como batelada até o rendimento alcançar $0,8 \mathrm{~mol} \mathrm{H}_{2} \mathrm{~mol}_{\text {glicose }}{ }^{-1}$, em seguida o reator passou a ter operação continua. Nessa segunda etapa o TDH utilizado foi de $24 \mathrm{~h}$, e diferentes concentrações de glicose foram adicionadas, variando a COV entre 10, 15, 20 e $40 \mathrm{~g} \mathrm{~L}^{-1} \mathrm{~d}^{-1}$, sendo que a produção de $\mathrm{H}_{2}$ foi 4,6; 8,5; 9,27 e $15 \mathrm{~L} \mathrm{~d}^{-1}$, respectivamente. Porém, quando a COV aumentou de 20 para 40 $\mathrm{g} \mathrm{L}^{-1} \mathrm{~d}^{-1}$ o rendimento diminuiu de 0,9 para $0,8 \mathrm{~mol} \mathrm{H}_{2}$ molglicose $^{-1}$, demonstrando que apesar da manutenção do pH ácido, a COV influencia diretamente na produção de $\mathrm{H}_{2}$.

Estudos em reator com chicanas a partir do melaço de beterraba mostraram que o efluente apresentou um pH médio entre 4,3 e 4,4 na fase estável e o rendimento de $\mathrm{H}_{2}$ obtido foi de $32,5 \mathrm{~L} \mathrm{~d}^{-1}$. A COV e TDH utilizados nesse estudo foram 8,9 $\mathrm{kgDQO} \mathrm{m}^{-3} \mathrm{~d}^{-1} \mathrm{e}$ 13,5 horas, respectivamente. Os autores encontraram um rendimento entre 3,2 - 10,0 $\mathrm{LH}_{2}$ $\mathrm{d}^{-1}$ do $5^{\circ}$ ao $15^{\circ}$ dia de operação com um pH entre 3,6 e 4,3, período que sistema ainda não se encontrava estável (LI et al., 2007).

$\mathrm{O}$ reator de leito expandido (EGSB) também foi avaliado para a produção de $\mathrm{H}_{2}$ a partir de melaço de beterraba com um pH de 4,4 e COV de $120 \mathrm{kgDQO} \mathrm{m}^{-3} \mathrm{~d}^{-1}$. A taxa de produção de $\mathrm{H}_{2}$ para as condições impostas foi de $0,7 \mathrm{LH}_{2} \mathrm{~L}^{-1} \mathrm{~h}^{-1}$, e o rendimento de $\mathrm{H}_{2}$ de 3,5 mol mol${ }^{-1}$ sacarose. A concentração estimada de $\mathrm{H}_{2}$ no biogás para esse sistema foi entre 30 e $53 \%$ (GUO et al., 2008).

Como já citado no item 3.6, um dos microrganismos associados à produção de $\mathrm{H}_{2}$ são os do gênero Clostridium. Esses organismos são capazes de formar esporos, o que auxilia na sobrevivência em ambientes extremos de temperatura e pH (KIM et al., 2012; FERRAZ JR. et al., 2015). Outro organismo produtor de $\mathrm{H}_{2}$ em baixo pH são os 
Lactobacillus, os quais são extremamente tolerantes a meios ácidos (FUESS et al., 2018) e comumente encontrados em substratos provenientes de biorrefinarias, como vinhaça e melaço de cana-de-açúcar.

Apesar de existir uma faixa ideal de $\mathrm{pH}$ para a produção de hidrogênio, nota-se que o processo ocorre em ampla faixa e que a variação da temperatura, substrato, entre outros fatores também contribuem para a ocorrência de determinada rota metabólica, e consequentemente a eficiência na produção de $\mathrm{H}_{2}$. A produção de $\mathrm{H}_{2}$ é passível de ocorrer em ambientes ácidos, com $\mathrm{pH}$ abaixo de 5,0, devido ao favorecimento de comunidades microbiológicas específicas.

\subsection{Considerações finais}

A digestão anaeróbia em condições termofílicas é uma alternativa para minimizar passivos ambientais e como consequência, gerar energia na forma de biogás. Assim, a utilização dessa condição para a produção de biogás é uma vantagem principalmente quando se utilizam efluentes e/ou subprodutos industriais.

Nesse contexto, alguns subprodutos da indústria de álcool e açúcar, como a vinhaça e o bagaço, vêm sendo amplamente avaliados para a produção de biogás $\left(\mathrm{CH}_{4}\right.$ e $\left.\mathrm{H}_{2}\right)$ como forma de gestão de resíduos. Como abrangido na revisão de literatura, o melaço, subproduto da produção de açúcar apresenta características físico-químicas atrativas para essa finalidade ainda pouco exploradas.

Neste trabalho, foi proposta a avaliação da utilização do melaço de cana-de-açúcar para o tratamento anaeróbio em sistemas de duas fases e fase única, compostos por reatores de leito fixo estruturado com espuma de poliuretano (ASTBR). A utilização de dois sistemas teve como objetivo a comparação da produção de biogás.

No reator acidogênico do sistema de duas fases foi avaliada a produção de $\mathrm{H}_{2} \mathrm{em}$ condição ácida ( $\mathrm{pH} 4,00)$, e no reator metanogênico desse sistema foi avaliada a variação da carga orgânica volumétrica (COV). O desempenho do reator do sistema de fase única foi analisado a partir da variação da COV e da redução da concentração de bicarbonato de sódio $\left(\mathrm{NaHCO}_{3}\right)$. 


\section{MATERIAL E MÉTODOS}

\subsection{Caracterização das amostras de melaço de cana-de-açúcar}

O substrato utilizado como fonte de carbono é um subproduto das usinas sucroalcooleiras, o melaço, que foi coletado na Usina de álcool e açúcar do Grupo São Martinho, localizada na cidade de Pradópolis - SP. Foi utilizado melaço proveniente de duas coletas, uma realizada no ano de 2015, e outra no ano de 2016.

O melaço de cana-de-açúcar possui consistência pastosa, e por ser muito concentrado mantem suas características físico-químicas praticamente constantes ao longo do tempo. O substrato foi armazenado em câmara climatiza a $4^{\circ} \mathrm{C}$, sendo que para cada alimentação dos sistemas era realizada a diluição em água de uma massa conhecida de melaço para a obtenção da DQO desejada.

A caracterização dos melaços coletados está na Tabela 4.1 e foram realizadas de acordo com procedimentos e metodologias descritas no Standard Methods for the Examination of Water and Wastewater (APHA, 2005) para séries de matéria orgânica, carbono orgânico total, sulfato, fosfato, nitrogênio total kjeldahl (NTK) e amônia. Para a série de ácido e carboidratos foi utilizado cromatografia líquida de alta eficiência (HPLC), seguindo protocolo de GOMES et al. (2015). A concentração de melaço utilizado foi de 10 $\mathrm{g} \mathrm{L}^{-1}$.

Tabela 4.1 - Caracterização físico-química do melaço (coleta 2015 e 2016)

\begin{tabular}{cccc}
\hline Parâmetros & Unidades & $\begin{array}{c}\text { Coleta } \\
\mathbf{2 0 1 5}\end{array}$ & $\begin{array}{c}\text { Coleta } \\
\mathbf{2 0 1 6}\end{array}$ \\
\hline Carbono Orgânico total & $\mathrm{gC} \mathrm{Kg}^{-1}$ melaço & 125,00 & 201,90 \\
\hline DQOt & $\mathrm{gO}_{2} \mathrm{Kg}^{-1}$ melaço & 7308,00 & 6941,60 \\
\hline Sulfato & $\mathrm{g} \mathrm{Kg}^{-1}$ melaço & 26,60 & 22,70 \\
\hline Fosfato & $\mathrm{g} \mathrm{Kg}^{-1}$ melaço & $\mathrm{ND}$ & $\mathrm{ND}$ \\
\hline NTK & $\mathrm{gN}-\mathrm{NH}_{4}{ }^{+\mathrm{Kg}^{-1} \text { melaço }}$ & 3,00 & 3,10 \\
\hline Amônia & $\mathrm{gN}^{-\mathrm{NH}_{4}{ }^{+} \mathrm{Kg}^{-1} \text { melaço }}$ & 1,10 & 1,10 \\
\hline Glicose & $\mathbf{C a r b o i d r a t o s}$ & & \\
\hline Frutose & $\mathrm{g} \mathrm{Kg}^{-1}$ melaço & 244,30 & 206,00 \\
\hline & $\mathrm{g} \mathrm{Kg}^{-1}$ melaço & 84,50 & 61,45
\end{tabular}


Tabela 4.1 - Caracterização físico-química do melaço (coleta 2015 e 2016) (continuação)

\begin{tabular}{cccc}
\hline & Metais & & \\
\hline Chumbo & $\mathrm{mgPb} \mathrm{Kg}^{-1}$ melaço & $<\mathrm{LD}$ & $<\mathrm{LD}$ \\
\hline Cobre & $\mathrm{mgCu} \mathrm{Kg}^{-1}$ melaço & $<\mathrm{LD}$ & $<\mathrm{LD}$ \\
\hline Cromo & $\mathrm{mgCr} \mathrm{Kg}^{-1}$ melaço & 0,85 & 0,59 \\
\hline Ferro & $\mathrm{mgFe} \mathrm{Kg}^{-1}$ melaço & 61,90 & 97,53 \\
\hline Manganês & $\mathrm{mgMn} \mathrm{Kg}^{-1}$ melaço & 30,67 & 24,60 \\
\hline Níquel & $\mathrm{mgNi} \mathrm{Kg}^{-1}$ melaço & $<\mathrm{LD}$ & $<\mathrm{LD}$ \\
\hline Zinco & $\mathrm{mg} \mathrm{Zn} \mathrm{Kg}^{-1}$ melaço & 5,35 & 5,41 \\
\hline Ácido cítrico & Ácidos orgânicos voláteis & & \\
\hline Ácido málico & $\mathrm{g} \mathrm{Kg}^{-1}$ melaço & 158,40 & 62,20 \\
\hline Ácido Succínico & $\mathrm{g} \mathrm{Kg}^{-1}$ melaço & 31,30 & 96,45 \\
\hline Ácido lático & $\mathrm{g} \mathrm{Kg}^{-1}$ melaço & $<\mathrm{LD}$ & 35,90 \\
\hline Ácido fórmico & $\mathrm{g} \mathrm{Kg}^{-1}$ melaço & $<\mathrm{LD}$ & 13,20 \\
\hline Ácido propiônico & $\mathrm{g} \mathrm{Kg}^{-1}$ melaço & $<\mathrm{LD}$ & 30,13 \\
\hline
\end{tabular}

$<\mathrm{L} / \mathrm{D}$ abaixo do limite de detecção do método

ND não detectável

\subsection{Aspectos gerais}

Os reatores do sistema de duas fases, acidogênico e metanogênico, com configurações apresentadas a seguir (item 4.3), foram anteriormente utilizados por VILELA (2017) para a avaliação da produção de biogás $\left(\mathrm{H}_{2}\right.$ e $\left.\mathrm{CH}_{4}\right)$ a partir do melaço de cana-de-açúcar. Os reatores foram montados nas dependências do Laboratório de Processos Biológicos do Departamento de Hidráulica e Saneamento (LPB/EESC/USP).

Para o sistema acidogênico, VILELA (2017) testou dois tipos de material suporte: espuma de poliuretano e polietileno de baixa densidade. O TDH utilizado foi de 2 horas, e carga orgânica volumétrica (COV) de 30, 60 e 120 gDQO L $\mathrm{L}^{-1} \mathrm{~d}^{-1}$. Para o reator metanogênico foi utilizado apenas espuma de poliuretano com TDH variando entre 240 e 12 horas, e COV de 1 e 25 gDQO L-1 $\mathrm{d}^{-1}$. A inoculação dos sistemas acidogênicos ocorreu pela autofermentação da vinhaça, e o reator metanogênico foi inoculado com lodo de reator UASB. 
Os reatores acidogênicos foram alimentados com melaço de cana-de-açúcar devidamente diluído em água de abastecimento para obtenção da demanda química orgânica (DQO) desejada para cada fase. O reator metanogênico do sistema combinado estava em série com o primeiro reator, e era alimentado com o efluente acidificado.

A partir da avaliação a produção de $\mathrm{H}_{2}$, ácidos orgânicos, rendimento de conversão de carboidratos foi escolhido o melhor meio suporte para o reator acidogênico. O sistema com espuma de poliuretano foi o mais eficiente para essa finalidade e condições impostas.

Assim, o início deste projeto ocorreu com reatores previamente adaptados para a produção de biogás em condições termofílicas e em operação continua. O reator acidogênico (ASTBR - A) foi operado por VILELA (2017) por um período de 417 dias, sendo utilizada em sua última fase uma COV $120 \mathrm{gDQO} \mathrm{L}^{-1} \mathrm{~d}^{-1}$ e DQO de $10 \mathrm{~g} \mathrm{~L}^{-1}$, ao início desse projeto o reator ainda estava em operação . O reator metanogênico de segunda fase (ASTBR - M II) foi operado por 251 dias. Sua última fase apresentava COV 17,50 gDQO $\mathrm{L}^{-1} \mathrm{~d}^{-1}$, DQO de $11 \mathrm{~g} \mathrm{~L}^{-1}$ e TDH de 12 horas e o mesmo permaneceu sem alimentação anteriormente ao início da presente pesquisa.

\subsection{Procedimentos experimentais: Reatores e condições operacionais}

Para atingir os objetivos apresentados no Item 2, foram operados dois sistemas, ou seja, um com dois reatores em série (sistema de duas fases) e outro de fase única (sistema único). Os reatores de leito fixo estruturado com espumas de poliuretano foram denominados de ASTBR (Anaerobic structured-bed reactor). O primeiro sistema foi composto por dois reatores em série, sendo primeiro acidogênico (ASTBR - A) e o segundo metanogênico (ASTBR - M II). O segundo sistema foi constituído por um único reator acidogênico/metanogênico (ASTBR - M I). A Figura 4.1 apresenta o fluxograma das etapas experimentais para os dois sistemas estudados. 


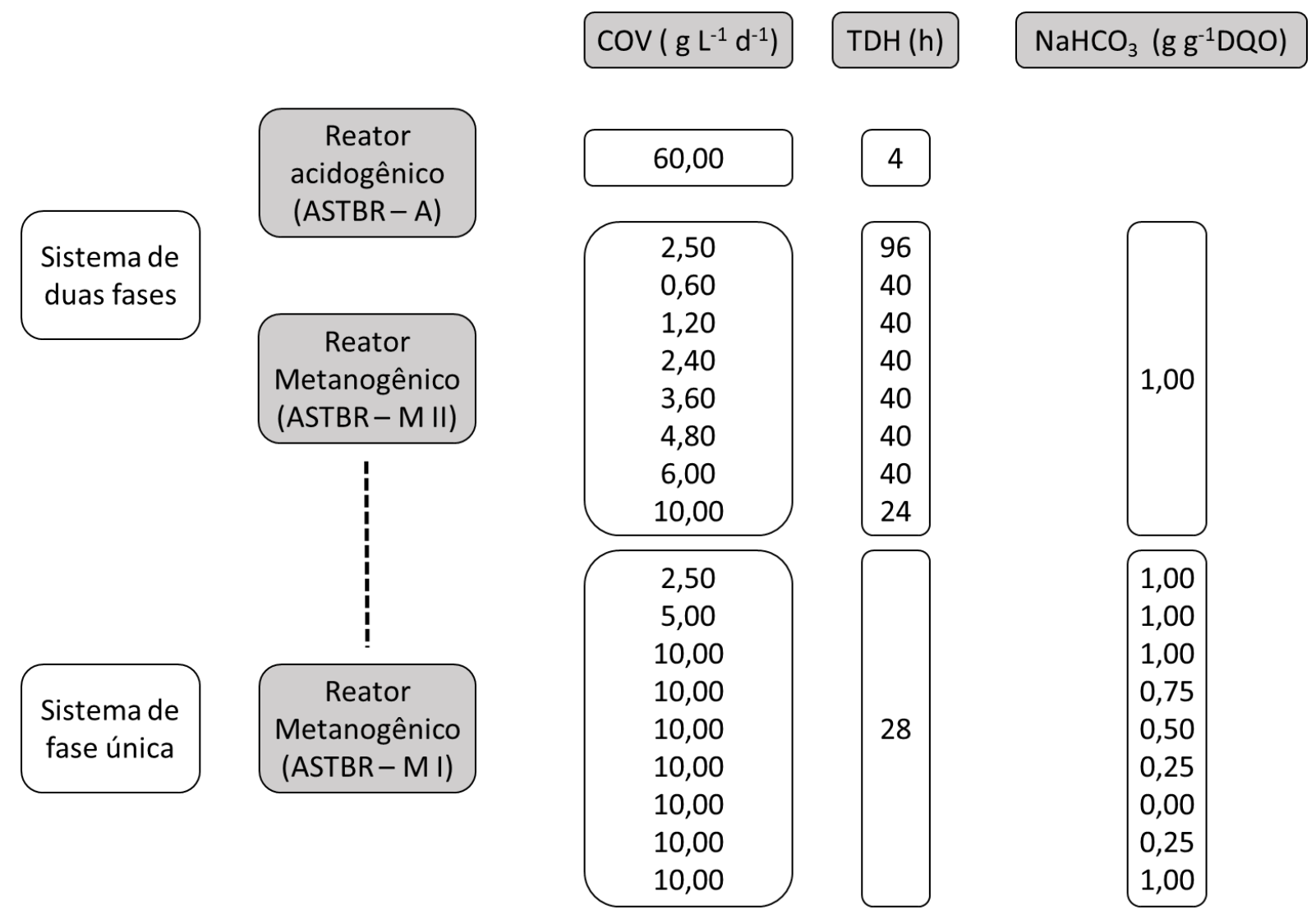

Figura 4.1 - Fluxograma das etapas experimentais

4.3.1 Reator acidogênico (ASTBR-A) - sistema de duas fases

O reator acidogênico (ASTBR - A) foi construído em acrílico com volume útil de 1,65 L, diâmetro interno de $60 \mathrm{~mm}$ e $800 \mathrm{~mm}$ e comprimento. O reator apresenta leito fixo, contendo seis hastes de espuma de poliuretano $(10 \times 10 \times 500 \mathrm{~mm})$ fixas em telas de aço inoxidável alocadas na estrutura de acrílico. A Figura 4.2 é uma imagem do reator utilizado para o sistema acidogênico do sistema de duas fases. 

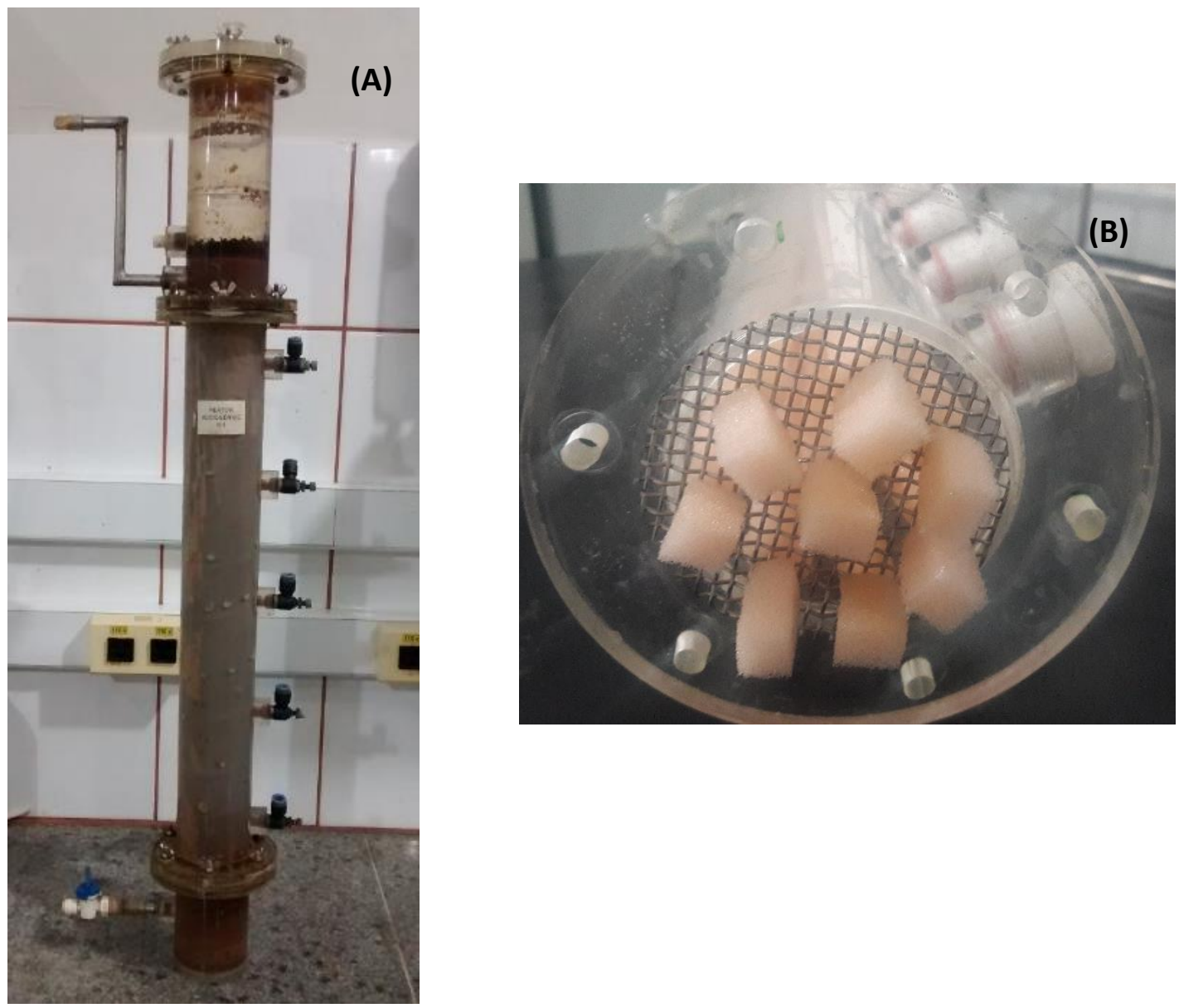

Figura 4.2 Detalhes do reator ASTBR - A: (A) Estrutura do reator, com ponto de entrada e saída; (B) Espuma de poliuretano utilizado como meio suporte da biomassa fixas em tela de aço inoxidável.

O reator foi continuamente operado em condições controladas de temperatura $\left(55^{\circ} \mathrm{C}\right)$ com fluxo ascendente por auxílio de uma bomba peristáltica Gilson, modelo Minipuls, e a vazão de gás monitorada por meio de um gasômetro da marca Ritter $®$. Como explicado no item 4.2, esse sistema já estava em operação no início desse trabalho, por isso não foi necessário inoculação e período de adaptação da biomassa. Para a presente pesquisa, o reator ASTBR - A foi operado por 392 dias com única fase de operação (Tabela 4.2). A carga orgânica volumétrica foi de $60 \mathrm{~g} \mathrm{~L}^{-1} \mathrm{~d}^{-1}$, o tempo de detenção hidráulico (TDH) de 4 horas e a demanda química de oxigênio afluente (DQOaf) de $10 \mathrm{~g} \mathrm{~L}^{-1}$. A alimentação do reator foi realizada por meio da diluição de $12 \mathrm{~g} \mathrm{~L}^{-1}$ de melaço em água de abastecimento. Nenhum alcalinizante foi adicionado para a correção do $\mathrm{pH}$. 
Tabela 4.2 - Condições operacionais aplicadas ao reator ASTBR - A

\begin{tabular}{cccccc}
\hline Fase & $\begin{array}{c}\text { DQO } \\
\left(\mathbf{g ~ L}^{-1}\right)\end{array}$ & $\begin{array}{c}\text { COV } \\
\left(\mathbf{g ~ L}^{-1} \mathbf{d}^{-\mathbf{1}}\right)\end{array}$ & $\begin{array}{c}\text { TDH } \\
(\mathbf{h})\end{array}$ & $\begin{array}{c}\text { Tempo de operação } \\
(\mathbf{d})\end{array}$ & $\begin{array}{c}\text { NaHCO3 } \\
\left(\mathbf{g ~ g}^{-\mathbf{1}} \mathbf{D Q O}\right)\end{array}$ \\
\hline I & 10,0 & 60,0 & 4 & $0-392$ & - \\
\hline
\end{tabular}

A operação desse reator por mais de um ano em apenas uma única condição ocorreu para a avaliação da estabilidade da produção de $\mathrm{H}_{2}$ a partir do melaço de cana-deaçúcar e sobretudo devido a necessidade da produção de efluente acidificado para alimentação do reator metanogênico (ASTBR - M II) que foi operado em série com o reator acidogênico.

\subsubsection{Reator metanogênico - sistema de duas fases (ASTBR-M II)}

Os equipamentos utilizados para operação do reator metanogênico foram semelhantes ao do reator ASTBR - A. Foi necessário um gasômetro da marca Ritter® para controle da produção de biogás, bomba peristáltica modelo Miniplus para a alimentação do reator com fluxo ascendente, sete hastes de espumas de poliuretano (10x10x500 mm) fixas em tela de aço inoxidável, e um reator em acrílico, com volume de aproximadamente 1,65 L, diâmetro interno de $60 \mathrm{~mm}$ e $800 \mathrm{~mm}$ de comprimento.

Na Figura 4.3 são apresentados os detalhes do sistema de duas fases, bem como as imagens do sistema em câmara climatizada e da alimentação. O efluente acidificado do reator ASTBR-A foi armazenado em galão para posterior diluição e correção do pH para ser utilizado como afluente (melaço acidificado) do sistema ASTBR - M II. Para correção de $\mathrm{pH}$ e geração de alcalinidade no reator ASTBR - M II foi utilizado a concentração de $1 \mathrm{gNaHCO}_{3} \mathrm{~g}^{-1} \mathrm{DQO}$ durante toda a operação do sistema, variando entre as fases apenas a concentração de melaço acidificado e consequentemente a DQO. A adição álcali na forma de bicarbonato de sódio $\left(\mathrm{NAHCO}_{3}\right)$, além de corrigir o baixo $\mathrm{pH}$, auxilia na manutenção da capacidade tampão do sistema. 
(A)
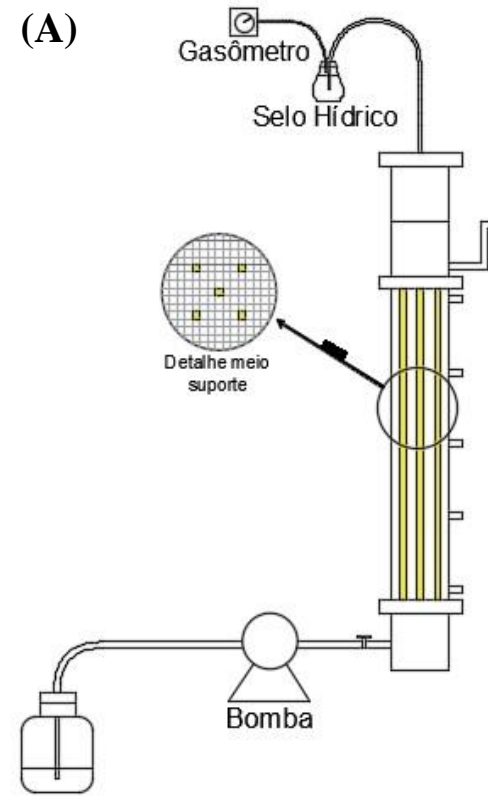

Melaço Diluído
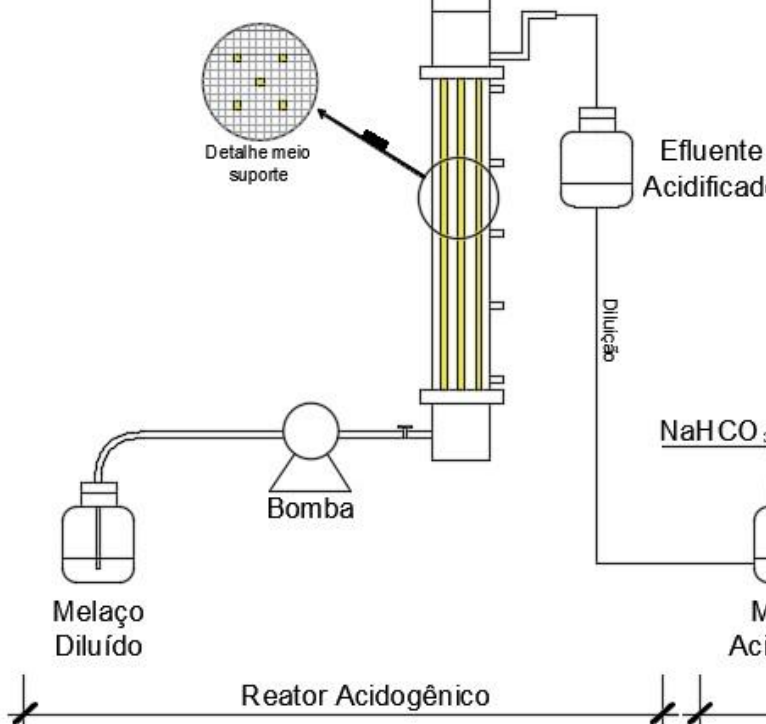

Reator Metanogênico
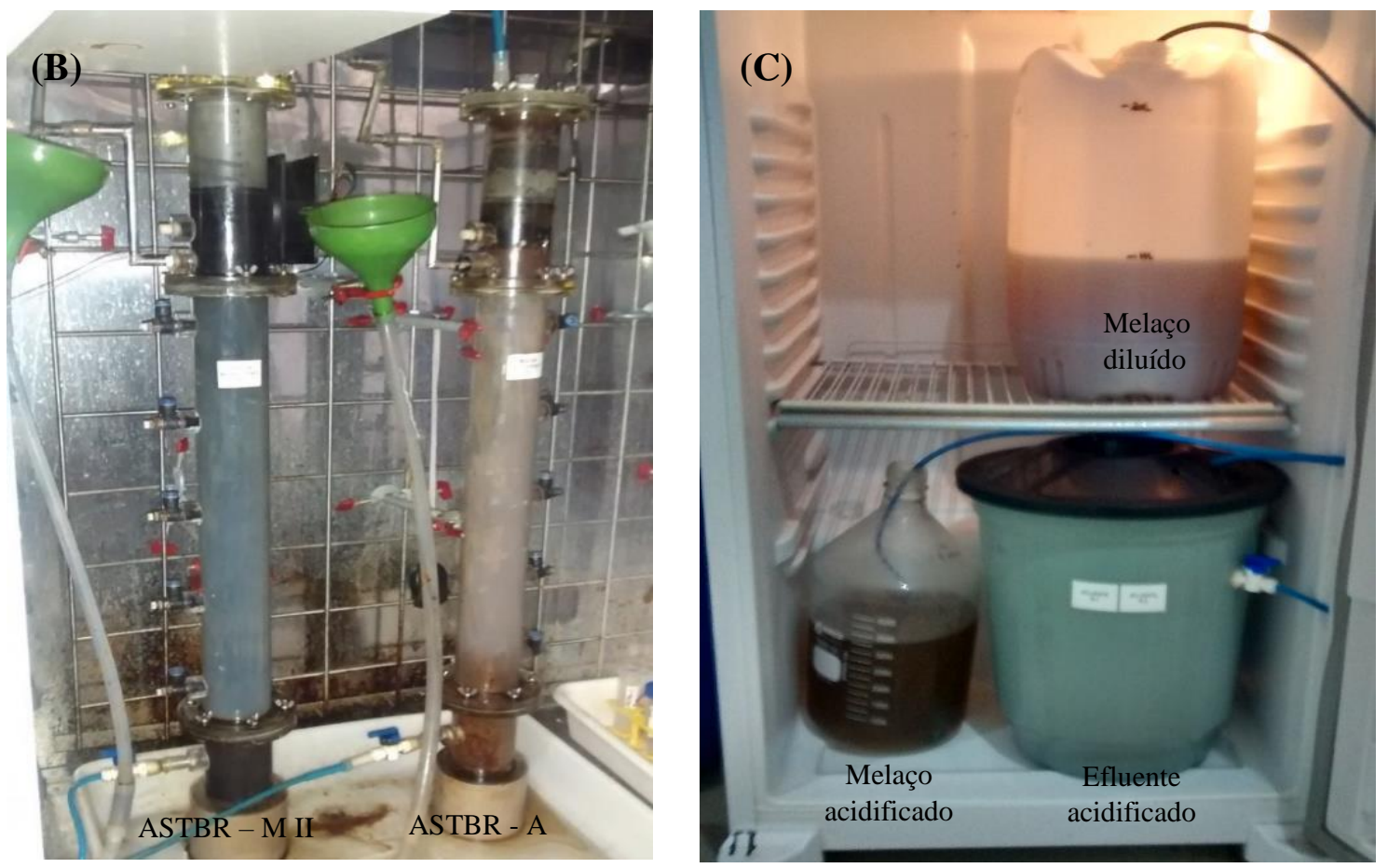

Figura 4.3 - Detalhes do reator ASTBR - M II. (A) desenho esquemático do sistema combinado em série;(B) Imagem dos reatores ASTBR - A e ASTBR - M I alocados na câmara climatizada; (C) Imagem da alimentação do sistema 
Pela composição do melaço (item 4.2, Tabela 4.1) nota-se baixa concentração de macro e micronutrientes, por isso a alimentação foi complementada com uma solução de nutrientes contendo nitrogênio e fósforo - Tabela 4.3. A solução foi adicionada respeitando a relação carbono, representado pela DQO, nitrogênio e fósforo (DQO:N:P) de 1000:5:1. Além da solução de nutrientes foi adicionada $1 \mathrm{~mL}$ de solução de vitaminas por litro de alimentação. A solução de vitaminas utilizada foi descrita por TOUZEL; ALBAGNAC (1983) (Tabela 4.4). A complementação com essa solução ocorreu com objetivo de melhorar o desempenho dos microrganismos do sistema após a fase IVa, quando houve uma queda na produção de gás $\mathrm{CH}_{4}$, associada à queda na eficiência de remoção de matéria orgânica.

Tabela 4.3 - Solução de nutrientes

\begin{tabular}{cc}
\hline Reagente & Concentração da solução estoque $\left(\mathbf{g ~ L}^{\mathbf{- 1}}\right)$ \\
\hline Cloreto de Amónio $\left(\mathrm{NH}_{4} \mathrm{Cl}\right)$ & 175,71 \\
\hline Hidrogenofostafo de Potássio $\left(\mathrm{KH}_{2} \mathrm{PO}_{4}\right)$ & 15,81 \\
\hline
\end{tabular}

Tabela 4.4 - Solução de vitaminas ( Fonte: Touzel e Albagnac, 1983)

\begin{tabular}{cc}
\hline Reagente & Concentração da solução estoque $\left(\mathbf{g ~ L}^{\mathbf{1}}\right)$ \\
\hline Biotina & 0,002 \\
\hline Ácido fólico & 0,002 \\
\hline Tiamina & 0,005 \\
\hline Riboflavina & 0,005 \\
\hline Ácido Nicotínico & 0,005 \\
\hline Pantotenato de cálcio & 0,005 \\
\hline Piridoxina & 0,01 \\
\hline Vitamina B12 & 0,0001 \\
\hline Ácido Lipóico & 0,005 \\
\hline Ácido p-aminobenzóico & 0,005 \\
\hline
\end{tabular}

O reator ASTBR - M II foi operado por 344 dias em oito fases. Na Fase I denominada de repartida do sistema optou-se por utilização de TDH de 96 horas, e COV de 2,5 $\mathrm{g} \mathrm{L} \mathrm{L}^{-1} \mathrm{~d}^{-1}$, entretanto essas condições não foram suficientes para o retorno do 
desempenho do sistema, resultando na segunda fase. A fase II foi realizada com TDH de 40 horas e COV de $0,6 \mathrm{~g} \mathrm{~L}^{-1} \mathrm{~d}^{-1}$. A partir da Fase II até a fase VII o TDH foi mantido em 40 horas, variando apenas a COV. Na Fase III, IVa e Va foram utilizadas COV de 1,2, 2,4, 4,8 $\mathrm{g} \mathrm{L}^{-1} \mathrm{~d}^{-1}$, respectivamente. Entretanto o aumento para COV de $4,8 \mathrm{~g} \mathrm{~L}^{-1} \mathrm{~d}^{-1}$ acarretou na instabilidade do sistema, gerando o retorno da operação em COV de 2,4 $\mathrm{g} \mathrm{L}^{-1} \mathrm{~d}^{-1}$ (Fase $\mathrm{IVb}$ ). A Fase VI teve COV de 3,6 $\mathrm{g} \mathrm{L}^{-1} \mathrm{~d}^{-1}$, a Fase Vb COV de $4,8 \mathrm{~g} \mathrm{~L}^{-1} \mathrm{~d}^{-1}$ e a Fase VII, COV de $6,0 \mathrm{~g} \mathrm{~L}^{-1} \mathrm{~d}^{-1}$. A última fase do reator metanogênico do sistema de duas fases (Fase VIII) apresentou COV de $10,0 \mathrm{~g} \mathrm{~L}^{-1} \mathrm{~d}^{-1}$ e o $\mathrm{TDH}$ foi reduzido para 24 horas.

Na Tabela 4.5 é apresentada um resumo das condições operacionais para cada fase do reator ASTBR - M II.

Tabela 4.5 - Condições operacionais aplicadas ao reator ASTBR - M II

\begin{tabular}{cccccc}
\hline Fases & $\begin{array}{c}\text { DQO } \\
\left(\mathbf{g ~ L}^{-\mathbf{1}}\right)\end{array}$ & $\begin{array}{c}\mathbf{C O V} \\
\left(\mathbf{g ~ L}^{-\mathbf{1}} \mathbf{d}^{-\mathbf{1}}\right)\end{array}$ & $\mathbf{T D H}(\mathbf{h})$ & Tempo de operação $(\mathbf{d})$ & $\begin{array}{c}\text { NaHCO3 } \\
\left(\mathbf{g ~ g}^{-\mathbf{1}} \mathbf{D Q O}\right)\end{array}$ \\
\hline I & 10,0 & 2,5 & 96 & $0-59$ & 1,00 \\
\hline II & 1,00 & 0,6 & 40 & $60-105$ & 1,00 \\
\hline III & 2,00 & 1,2 & 40 & $106-125$ & 1,00 \\
\hline IVa & 4,00 & 2,4 & 40 & $126-146$ & 1,00 \\
\hline Va & 8,00 & 4,8 & 40 & $147-176$ & 1,00 \\
\hline IVb & 4,00 & 2,4 & 40 & $177-246$ & 1,00 \\
\hline VI & 6,00 & 3,6 & 40 & $247-261$ & 1,00 \\
\hline Vb & 8,00 & 4,8 & 40 & $261-274$ & 1,00 \\
\hline VII & 10,0 & 6,0 & 40 & $275-306$ & 1,00 \\
\hline VIII & 10,0 & 10,0 & 24 & $307-344$ & 1,00 \\
\hline
\end{tabular}

Como a biomassa do reator ASTBR - M II foi utilizada para a operação do sistema em fase única (ASTBR - M I) não foi testada a variação da concentração de $\mathrm{NaHCO}_{3}$, afim de não prejudicar as comunidades microbiológicas aderidas ao material suporte para a próxima etapa.

\subsubsection{Reator metanogênico - sistema de fase única (ASTBR-M I)}

O segundo sistema para análise da produção de biogás foi um sistema de fase única composto por um reator metanogênico (ASTBR - M I). Esse reator também possuiu fluxo ascendente, gasômetro (Ritter®) para medição da vazão do biogás e bomba peristáltica para alimentação do sistema. 
Na Figura 4.4 são apresentadas as principais características do sistema de fase única (ASTBR - M I). O reator e a espuma de poliuretano apresentaram mesma configuração do reator do sistema combinado ASTBR - M II (volume útil de 1,65 L, diâmetro interno de 60 $\mathrm{mm}, 800 \mathrm{~mm}$ de comprimento total e $500 \mathrm{~mm}$ de comprimento do leito) uma vez que foi utilizado o mesmo reator e biomassa. Em relação ao material suporte foram utilizadas sete espumas de poliuretano $(10 \times 10 \times 500 \mathrm{~mm})$ fixas em tela de aço inoxidável.

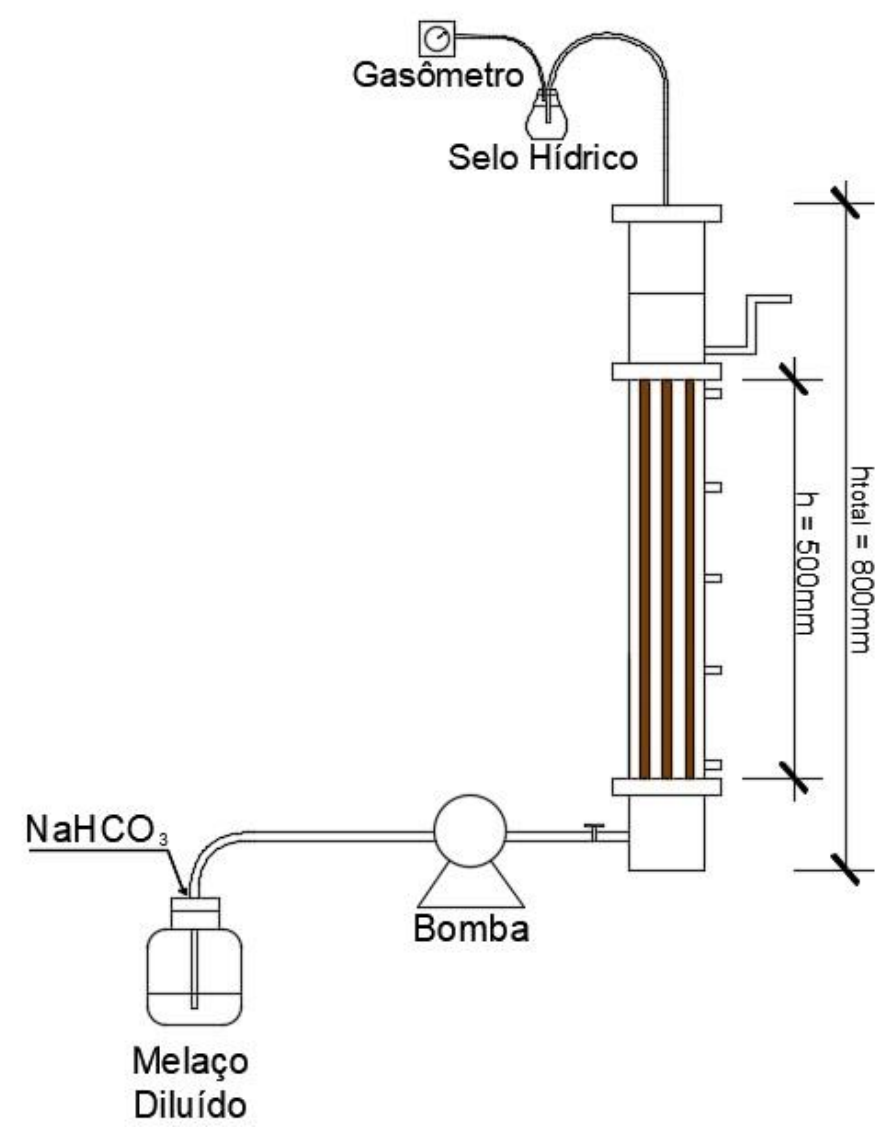

Figura 4.4 - Desenho esquemático do reator metanogênico do sistema único (ASTBR - M I)

O reator ASTBR - M I foi operado por 192 dias. A alimentação desse reator diferese do reator ASTBR - M II por não ser com melaço acidificado, mas com melaço diluído em água de abastecimento (similar a alimentação do reator ASTBR - A). Nesse sistema também foi adicionado alcalinizante na forma de bicarbonato $\left(\mathrm{NaHCO}_{3}\right)$, solução de nutrientes (Tabela 4.3) e solução de vitaminas (Tabela 4.4).

O sistema de fase única foi operado em 9 fases, diferenciadas pelas condições operacionais, entretanto submetido ao TDH constante de 28 horas. A escolha do TDH para o sistema de fase única ocorreu pela soma dos TDH do sistema combinado, sendo que o 
reator ASTBR - A foi operado com TDH de 4 horas e a última fase do reator ASTBR - M II (Fase VIII) foi executada com TDH de 24 horas.

Nesse sistema único além da produção de biogás e conversão de matéria orgânica, também foi possível a verificação da influência da variação de $\mathrm{NaHCO}_{3}$ na metanogênese em um sistema com substrato facilmente degradado, bem como o retorno da metanogênese após a acidificação do sistema.

O sistema de fase única foi operado com a biomassa adaptada às condições de temperatura $\left(55^{\circ} \mathrm{C}\right)$ e ao substrato, melaço de cana-de-açúcar, uma vez que a biomassa proveio do sistema de duas fases. A Fase I teve COV de $2,5 \mathrm{~g} \mathrm{~L}^{-1} \mathrm{~d}^{-1}$, Fase II $5,0 \mathrm{~g} \mathrm{~L}^{-1} \mathrm{~d}^{-1} \mathrm{e}$ Fase III 10,0 $\mathrm{g} \mathrm{L}^{-1} \mathrm{~d}^{-1}$. Para as três primeiras fases, a concentração de alcalinizante foi mantida em $1 \mathrm{gNaHCO}_{3} \mathrm{~g}^{-1} \mathrm{DQO}$. Da Fase IV até a VII a concentração de bicarbonato do sistema foi reduzida gradualmente, mantendo a mesma carga orgânica volumétrica da Fase III. Ao retirar o $\mathrm{NaHCO}_{3}$ completamente o sistema metanogênico entrou em colapso e o reator tornou-se apenas de fase ácida. Estratégias foram adotadas para que a metanogênese fosse recuperada. Concentrações crescentes de álcali passaram a ser dosadas no reator (fases VIII a IX, com 0,25 e 1,0 $\mathrm{gNaHCO}_{3} \mathrm{~g}^{-1} \mathrm{DQO}$, respectivamente). As fases, cargas orgânicas volumétricas, TDH, tempo de operação e concentração de alcalinizante impostas durante o experimento são apresentadas na Tabela 4.6.

Tabela 4.6 - Condições operacionais aplicadas ao reator ASTBR - M I

\begin{tabular}{cccccc}
\hline Fases & $\begin{array}{c}\text { DQO } \\
\left(\mathbf{g ~ L}^{-\mathbf{1}}\right)\end{array}$ & $\begin{array}{c}\mathbf{C O V} \\
\left(\mathbf{g ~ L}^{-\mathbf{1}} \mathbf{d}^{-\mathbf{1}}\right)\end{array}$ & $\mathbf{T D H}(\mathbf{h})$ & $\mathbf{T e m p o}$ de operação $(\mathbf{d})$ & $\begin{array}{c}\text { NaHCO3 } \\
\left(\mathbf{g ~ g}^{-\mathbf{1}} \mathbf{D Q O}\right)\end{array}$ \\
\hline I & 2,90 & 2,5 & 28 & $0-22$ & 1,00 \\
\hline II & 5,80 & 5,0 & 28 & $23-56$ & 1,00 \\
\hline III & 11,70 & 10,0 & 28 & $57-102$ & 1,00 \\
\hline IV & 11,70 & 10,0 & 28 & $103-117$ & 0,75 \\
\hline V & 11,70 & 10,0 & 28 & $117-136$ & 0,50 \\
\hline VI & 11,70 & 10,0 & 28 & $137-150$ & 0,25 \\
\hline VII & 11,70 & 10,0 & 28 & $151-171$ & 0,00 \\
\hline VIII & 11,70 & 10,0 & 28 & $172-178$ & 0,25 \\
\hline IX & 11,70 & 10,0 & 28 & $179-188$ & 1,00
\end{tabular}

\subsection{Avaliação do desempenho dos reatores: Métodos analíticos e cálculos}

O desempenho dos reatores ao longo do período de operação foi avaliado por parâmetros como: pH, alcalinidade parcial (Ap) e intermediária (AI) (sistemas metanogênicos), demanda de oxigênio total (DQOt) e solúvel (DQOs), sólidos suspensos 
totais (SST), voláteis (SSV) e fixos (SSF), carboidratos totais $(\mathrm{CHt})$ e solúveis $(\mathrm{CHs})$, ácidos voláteis totais e ácidos graxos voláteis (AGV). As análises dos três sistemas foram realizadas para amostras do melaço diluído (afluente), acidificado (efluente do reator ASTBR - A), e biodigerida (efluente ASTBR - M II e ASTBR - M I).

- DQOt, DQOs, SST, SSV e SSF: Esses parâmetros foram analisados de acordo com protocolo descrito no Standard Methods of Water and Wastewater (APHA, 2005). Nas análises de DQOs as amostras foram filtradas em membrana de 0,45 $\mu \mathrm{m}$, enquanto que a análise de sólidos foi utilizada membranas de 1,2 $\mu \mathrm{m}$ para filtrar as amostras;

- Carboidratos totais e solúveis: A concentração de carboidratos foi realizada de acordo com o método de DUBOIS et al. (1956); BLUNDI, S.F., GADÊLHA (2001), conhecido como método fenol-sulfúrico. Esse método consiste na leitura da absorbância da solução em $490 \mathrm{~nm}$ após a desidratação dos carboidratos da amostra pela ação do ácido sulfúrico concentrado na presença de fenol. Essa análise foi realizada para amostras antes e após filtração em membrana de $0,45 \mu \mathrm{m}$. A curva de calibração $\left(20-180 \mathrm{mg}_{\text {sacarose }} \mathrm{L}^{-1}\right)$ foi feita com solução $1 \%$ de sacarose, portanto as leituras foram obtidas em g $_{\text {sacarose }}$ por litro de melaço diluído.

- Alcalinidade parcial (AP) e intermediária (AI): Utilizou-se a metodologia de DILALLO, R. \& ALBERTSON, 1961 modificada por RIPLEY et al. (1986) por meio de titulometria potenciométrica;

- Ácidos orgânicos voláteis totais: Esse parâmetros foi avaliado pelo método de titulação proposta por DILALLO, R. \& ALBERTSON (1961). Antes da titulação foi realizada a fervura das amostras entre três e cinco minutos para remoção do $\mathrm{CO}_{2}$;

- Ácidos orgânicos: Esse parâmetro foi avaliado por dois métodos, sendo que amostras do reator ASTBR - A foi realizada por cromatografia liquida de alta eficiência (HPLC), enquanto que para as amostras dos reatores ASTBR - M II e ASTBR- M I utilizou-se cromatográfica gasosa (GC). A utilização de métodos diferentes ocorreu devido a grande diferença de concentrações de ácidos entre as amostras dos reatores acidogênico e metanogênicos. Em HPLC foram detectados os ácidos cítrico, lático, fórmico, acético, propriônico e butírico. Em 
GC foram determinados ácidos como o acético, propiônico, butírico e isobutírico. Para analise em HPLC foi utilizado sistema Shimadzu ${ }^{\circledR}$ equipado com bomba LC-10ADVP, válvula FCV-10ALVP, detector ultravioleta (UV) com arranjo de diodos (SPD-M10 AVP), injetor Rheodyne (® (100 $\mu \mathrm{L}$ loop) e coluna Aminex ${ }^{\circledR}$ HPX-87H (300 mm x 7,8 mm x Bio58 Rad). A elaboração das curvas de calibração do HPLC seguiu as recomendações do fabricante e a preparação das amostras seguiu metodologia descrita em GOMES et al. (2015) . A análise gasosa foi realizada em cromatógrafo gasoso modelo GC 2010 (Shimadzu®), equipado com detector de ionização de chama (FID) e coluna HP-INNOWAX (30 mm de comprimento, 0,25 mm de diâmetro interno e 0,25 $\mu \mathrm{m}$ de espessura de filme). Para preparo das amostras e limites de detecção foi utilizada a metodologia descrita por (ADORNO et al., 2014). 
Tabela 4.7 - Análises e métodos analíticos para monitoramento dos reatores

\begin{tabular}{|c|c|c|c|c|}
\hline Reator & Parâmetro & $\begin{array}{c}\text { Frequência na } \\
\text { semana }\end{array}$ & Método & Referência \\
\hline \multirow{8}{*}{$\frac{\mathbb{1}}{4}$} & DQOt e DQOs & $2 \mathrm{x}$ & Espectrofotométrico & APHA (2005) \\
\hline & $\mathrm{pH}$ & $2 \mathrm{x}$ & Potenciométrico & APHA (2005) \\
\hline & Ácidos voláteis & $2 x$ & Titulométrico/ potenciométrico & DILALLO, R. \& ALBERTSON (1961) \\
\hline & Ácidos orgânicos & $1 \mathrm{x}$ & Cromatografia líquida & GOMES et al. (2015) \\
\hline & SSV & Quinzenal & Gravimétrico & APHA (2005) \\
\hline & $\mathrm{CHt}$ e CHs & $2 \mathrm{x}$ & Espectrofotométrico & DUBOIS et al. (1956) \\
\hline & Vazão de biogás & Diária & & - \\
\hline & Composição do biogás & $3 x$ & Cromatografia gasosa & PERNA et al. (2013) \\
\hline \multirow{9}{*}{ 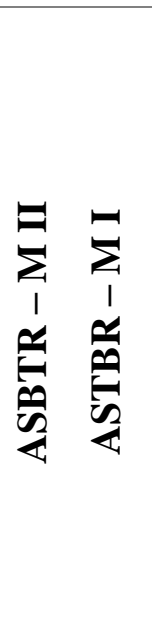 } & DQOt e DQOs & $2 \mathrm{x}$ & Espectrofotométrico & APHA (2005) \\
\hline & $\mathrm{pH}$ & $2 \mathrm{x}$ & Potenciométrico & APHA (2005) \\
\hline & Ácidos voláteis & $2 \mathrm{x}$ & Titulométrico/ Potenciométrico & DILALLO, R. \& ALBERTSON (1961) \\
\hline & Ácidos orgânicos & $1 \mathrm{x}$ & Cromatografia gasosa & ADORNO et al. (2014) \\
\hline & SSV & Quinzenal & Gravimétrico & APHA (2005) \\
\hline & $\mathrm{CHt}$ e $\mathrm{CHs}$ & $2 \mathrm{x}$ & Espectrofotométrico & DUBOIS et al. (1956) \\
\hline & Alcalinidade & $2 \mathrm{x}$ & Titulométrico/ Potenciométrico & RIPLEY et al., 1986 \\
\hline & Vazão de biogás & diária & - & - \\
\hline & Composição do biogás & $3 x$ & Cromatografia gasosa & PERNA et al. (2013) \\
\hline
\end{tabular}


A fase gasosa dos reatores foi monitorada continuamente, utilizando gasômetros Ritter ${ }^{\circledR}$ acoplados ao headspace de cada sistema. A análise da composição do biogás hidrogênio $\left(\mathrm{H}_{2}\right)$, nitrogênio $\left(\mathrm{N}_{2}\right)$, metano $\left(\mathrm{CH}_{4}\right)$, e gás carbônico $\left(\mathrm{CO}_{2}\right)$ - foi realizada em cromatógrafo gasoso GC 2010 (Shimadzuß), equipado com detector de condutividade térmica (TCD), com coluna Carboxen ${ }^{\circledR} 1010$ Plot (30 mm de comprimento, 0,53 mm de diâmetro externo e $0,30 \mu \mathrm{m}$ de espessura), sendo o gás de arraste o argônio. As temperaturas do injetor e detector foram de $220^{\circ} \mathrm{C}$ e $230^{\circ} \mathrm{C}$, respectivamente. Sendo o tempo de corrida de aproximadamente 6 minutos (PERNA et al., 2013).

O desempenho do reator acidogênico (ASTBR - A) foi avaliado pelas seguintes variáveis: Eficiência de DQOt e DQOs; eficiência de CHt e CHs; vazão de biogás (VBG, em $\mathrm{mL} \mathrm{h}^{-1}$ ); produção volumétrica de hidrogênio ( $\mathrm{PVH}$, em $\mathrm{mLH}_{2} \mathrm{~L}^{-1} \mathrm{~h}^{-1}$ ); vazão molar de hidrogênio (VMH, em mmolH $\mathrm{h}^{-1}$ ); rendimento de hidrogênio ( $\mathrm{HY}$, em molH $\mathrm{mol}^{-1} \mathrm{CHt}$ ) e conteúdo de hidrogênio no biogás (\%).

Para os reatores metanogênicos (ASTBR - M II e ASTBR- M I) as variáveis analisadas para verificação do desempenho dos sistemas foram: Eficiência de DQOt e DQOs; eficiência de CHt e CHs; razão entre alcalinidade parcial e intermediaria (AI/AP); vazão de biogás (VBG, em $\mathrm{mL} \mathrm{h}^{-1}$ ); produção volumétrica de metano (PVM, em mL $\mathrm{CH}_{4}$ $\mathrm{L}^{-1} \mathrm{~h}^{-1}$ ); vazão molar de metano (VMM, em mmol $\mathrm{CH}_{4} \mathrm{~h}^{-1}$ ); rendimento de metano (MY, em $\left.\mathrm{mLCH}_{4} \mathrm{~g}^{-1} \mathrm{DQO}\right)$ e conteúdo de metano no biogás (\%).

As equações utilizadas para cálculo do desempenho dos reatores estão na Tabela 4.8. Para os valores de produção de biogás foram utilizadas as condições normais de temperatura e pressão (CNTP), sendo a pressão 1 atm e $0^{\circ}(273 \mathrm{~K})$ para a temperatura. Os valores de poder calorífico para o hidrogênio e metano foram descritos por PENTEADO et al. (2013) e SILES et al. (2011), respectivamente. 
Tabela 4.8 - Principais equações utilizadas para verificação do desempenho dos reatores

\begin{tabular}{|c|c|c|c|}
\hline VARIÁVEL & UNIDADE & EQUAÇÃO & \\
\hline \multirow{2}{*}{ Eficiência de remoção de DQO } & \multirow{2}{*}{$\%$} & \multirow{2}{*}{$\% \mathrm{DQO}=\left(\frac{D Q O a f-D Q O e f}{D Q O a f}\right) 100$} & DQOaf: DQO afluente $\left(\mathrm{g} \mathrm{L}^{-1}\right)$ \\
\hline & & & DQOef: DQ efluente $\left(\mathrm{g} \mathrm{L}^{-1}\right)$ \\
\hline \multirow{2}{*}{ Eficiência de conversão de $\mathrm{CH}$} & \multirow{2}{*}{$\%$} & \multirow{2}{*}{$\% \mathrm{CH}=\left(\frac{C H a f-C H e f}{C H a f}\right) 100$} & CHaf: carboidrato afluente $\left(\mathrm{g} \mathrm{L}^{-1}\right)$ \\
\hline & & & CHef: carboidrato efluente $\left(\mathrm{g} \mathrm{L}^{-1}\right)$ \\
\hline \multirow{2}{*}{ Vazão de biogás } & \multirow{2}{*}{$\mathrm{mL} \mathrm{h}^{-1}$} & \multirow{2}{*}{$\mathrm{VBG}=\frac{\text { Vgasômetro }}{\text { t mediçăo }}$} & $\mathrm{V}_{\text {gasômetro: }}$ volume de gás medido $(\mathrm{mL})$ \\
\hline & & & $\mathrm{t}_{\text {medição: }}$ tempo medição $(\mathrm{h})$ \\
\hline \multirow{3}{*}{ Produção volumétrica de $\mathrm{H}_{2}$} & \multirow{3}{*}{$\mathrm{mLH}_{2} \mathrm{~L}^{-1} \mathrm{~h}^{-1}$} & \multirow{3}{*}{$\mathrm{PVH}=\frac{\text { VBG. } \% H_{2}}{\text { Vreator }}$} & VBG: vazão de biogás $\left(\mathrm{mL} \mathrm{h}^{-1}\right)$ \\
\hline & & & $\% \mathrm{H}_{2}$ : porcentagem de $\mathrm{H}_{2}$ no biogás \\
\hline & & & $\mathrm{V}_{\text {reator: }}$ volume útil do reator $(\mathrm{L})$ \\
\hline \multirow{4}{*}{ Vazão molar de $\mathrm{H}_{2}$} & \multirow{4}{*}{$\mathrm{mmolH}_{2} \mathrm{~h}^{-1}$} & \multirow{4}{*}{$\mathrm{VMH}=\frac{P V H . P}{R \cdot T}$} & PVH: produção volumétrica de $\mathrm{H}_{2}\left(\mathrm{mLH}_{2} \mathrm{~L}^{-1} \mathrm{~h}^{-1}\right)$ \\
\hline & & & P: pressão (1 atm) \\
\hline & & & R: constate universal dos gases $\left(0,082\right.$ atm $\left.\mathrm{L} \mathrm{mol}^{-1} \mathrm{~K}^{-1}\right)$ \\
\hline & & & T: temperatura $(273 \mathrm{~K})$ \\
\hline \multirow{5}{*}{ Rendimento de $\mathrm{H}_{2}$} & \multirow{5}{*}{$\mathrm{molH}_{2} \mathrm{~mol}^{-1} \mathrm{CHt}$} & \multirow{5}{*}{$\mathrm{HY}=\frac{V M H}{\frac{(C H a f-C H e f) \cdot Q a f}{M \text { Macarose }}}$} & VMH: Vazão molar de $\mathrm{H}_{2}\left(\mathrm{mmol} \mathrm{H}_{2} \mathrm{~h}^{-1}\right)$ \\
\hline & & & CHaf: carboidrato afluente $\left(\mathrm{g} \mathrm{L}^{-1}\right)$ \\
\hline & & & CHef: carboidrato efluente $\left(\mathrm{g} \mathrm{L}^{-1}\right)$ \\
\hline & & & Qaf: vazão afluente ao reator $\left(\mathrm{L} \mathrm{h}^{-1}\right)$ \\
\hline & & & $\mathrm{M}_{\text {sacarose: }}$ massa molar da sacarose $\left(342,3 \mathrm{~g} \mathrm{~mol}^{-1}\right)$ \\
\hline \multirow{4}{*}{ Potencial energético } & \multirow{4}{*}{$\mathrm{kJ} \mathrm{L}^{-1}$} & \multirow{4}{*}{$\operatorname{PE}\left(\mathrm{H}_{2}\right)=\mathrm{CHaf} . \% \mathrm{CH} \cdot \mathrm{HY} \cdot \mathrm{PC}\left(\mathrm{H}_{2}\right)$} & CHaf: Carboidrato afluente $\left(\mathrm{g} \mathrm{L}^{-1}\right)$ \\
\hline & & & \%CH: Eficiência de conversão de carboidratos (\%) \\
\hline & & & HY: Rendimento de $\mathrm{H}_{2}\left(\mathrm{molH}_{2} \mathrm{~mol}^{-1} \mathrm{CHt}\right)$ \\
\hline & & & PC $\left(\mathrm{H}_{2}\right)$ : Poder calorífico do $\mathrm{H}_{2}\left(122 \mathrm{~kJ} \mathrm{~g}^{-1} \mathrm{H} 2\right.$ ou $\left.10,90 \mathrm{~kJ} \mathrm{~L}^{-1} \mathrm{H} 2\right)$ \\
\hline
\end{tabular}


Tabela 4.8 - Principais equações utilizadas para verificação do desempenho dos reatores (continuação)

\begin{tabular}{|c|c|c|c|}
\hline VARIÁVEL & UNIDADE & EQUAÇÃO & \\
\hline \multirow{3}{*}{ Produção volumétrica de $\mathrm{CH}_{4}$} & \multirow{3}{*}{$\mathrm{mLCH}_{4} \mathrm{~L}^{-1} \mathrm{~h}^{-1}$} & \multirow{3}{*}{$\mathrm{PVM}=\frac{V B G . \% C H 4}{\text { Vreator }}$} & VBG: vazão de biogás $\left(\mathrm{mL} \mathrm{h}^{-1}\right)$ \\
\hline & & & $\% \mathrm{CH}_{4}$ : porcentagem de $\mathrm{CH}_{4}$ no biogás \\
\hline & & & $\mathrm{V}_{\text {reator: }}$ volume útil do reator $(\mathrm{L})$ \\
\hline \multirow{4}{*}{ Vazão molar de $\mathrm{CH}_{4}$} & \multirow{4}{*}{$\mathrm{mmol} \mathrm{CH}_{4} \mathrm{~h}^{-1}$} & \multirow{4}{*}{$\mathrm{VMM}=\frac{P V M . P}{R \cdot T}$} & PVM: produção volumétrica de $\mathrm{CH}_{4}\left(\mathrm{mLCH}_{4} \mathrm{~L}^{-1} \mathrm{~h}^{-1}\right)$ \\
\hline & & & P: pressão (1 atm) \\
\hline & & & $\mathrm{R}$ : constate universal dos gases $\left(0,082\right.$ atm $\left.\mathrm{L} \mathrm{mol}^{-1} \mathrm{~K}^{-1}\right)$ \\
\hline & & & T: temperatura $(273 \mathrm{~K})$ \\
\hline \multirow{4}{*}{ Rendimento de $\mathrm{CH}_{4}$} & \multirow{4}{*}{$\mathrm{mLCH}_{4} \mathrm{~g}^{-1} \mathrm{DQO}$} & \multirow{4}{*}{$\mathrm{MY}=\frac{V B G . \% C H 4}{(\text { DQOaf }-D Q O e f) \cdot Q a f}$} & VBG: vazão de biogás $\left(\mathrm{mL} \mathrm{h}^{-1}\right)$ \\
\hline & & & DQOaf: DQO afluente $\left(\mathrm{g} \mathrm{L}^{-1}\right)$ \\
\hline & & & DQOef: DQ efluente ( $\left.\mathrm{g} \mathrm{L}^{-1}\right)$ \\
\hline & & & $\mathrm{Q}_{\mathrm{af}}$ : vazão afluente ao reator $\left(\mathrm{L} \mathrm{h}^{-1}\right)$ \\
\hline \multirow{4}{*}{$\begin{array}{c}\text { Conteúdo de } \mathrm{H}_{2}(\%), \mathrm{CH}_{4}(\%) \\
\text { e } \mathrm{CO}_{2}(\%) \text { no biogás }\end{array}$} & \multirow{4}{*}{$\%$} & \multirow{4}{*}{$\begin{aligned} \% \mathrm{H}_{2} & =\frac{n H 2}{n t} \\
\% \mathrm{CH}_{4} & =\frac{n H 2}{n t} \\
\% \mathrm{CO}_{2} & =\frac{n H 2}{n t}\end{aligned}$} & $\mathrm{nH}_{2}$ : número de mols de $\mathrm{H}_{2}(\mathrm{~mol})$ \\
\hline & & & nCH 4 : número de mols de $\mathrm{H}_{2}(\mathrm{~mol})$ \\
\hline & & & $\mathrm{nCO}_{2}$ : número de mols de $\mathrm{H}_{2}(\mathrm{~mol})$ \\
\hline & & & nt: $\mathrm{nH}_{2}+\mathrm{nCH}_{4}+\mathrm{nCO}_{2}(\mathrm{~mol})$ \\
\hline \multirow{4}{*}{ Potencial energético } & \multirow{4}{*}{$\mathrm{kJ} \mathrm{L}^{-1}$} & \multirow{4}{*}{$\mathrm{PE}\left(\mathrm{CH}_{4}\right)=$ DQOaf.\%DQO.MY.PC $\left(\mathrm{CH}_{4}\right)$} & DQOaf: Demanda química de oxigênio afluente $\left(\mathrm{g} \mathrm{L}^{-1}\right)$ \\
\hline & & & \%DQO: Eficiência de remoção de DQO (\%) \\
\hline & & & MY: Rendimento de $\mathrm{CH}_{4}\left(\mathrm{mLCH}_{4} \mathrm{~g}^{-1} \mathrm{DQO}\right)$ \\
\hline & & & PC $\left(\mathrm{CH}_{4}\right)$ : Poder calorífico do $\mathrm{CH}_{4}\left(50 \mathrm{~kJ} \mathrm{~g}^{-1} \mathrm{CH}_{4}\right.$ ou $\left.35,8 \mathrm{~kJ} \mathrm{~L}^{-1} \mathrm{CH}_{4}\right)$ \\
\hline
\end{tabular}




\subsubsection{Balanço de massa nos sistemas de reatores}

Com a finalidade de auxiliar na compreensão dos processos de remoção de matéria orgânica e conversão de carboidratos dos reatores ao longo de toda operação foi realizado o balanço de massa para os três sistemas, ASTBR - A, ASTBR - M II e ASTBR - M I. O balanço de massa $(\mathrm{BM})$ foi realizado a partir do monitoramento do efluente da fase líquida de cada sistema.

Para determinação do BM os ácidos orgânicos determinados por HPLC para o efluente acidificado, e GC para o efluente dos reatores metanogênicos foram transformados em equivalentes de matéria orgânica, medidos na forma de DQO pelas suas respectivas reações de oxidação. Para os compostos aferidos na forma de carboidratos solúveis também foi realizado o mesmo procedimento, considerando-os como sacarose.

A determinação dos ácidos orgânicos foi realizada em amostras filtradas em membrana de 0,45 $\mu \mathrm{m}$, visando reduzir os interferentes sólidos. A DQO e $\mathrm{CH}$ utilizados para os balanços de massa foram relativas às frações solúveis. A equação 1 foi utilizada para o BM, em que a DQO devida aos ácidos é a concentração de cada ácido obtido por cromatográfica multiplicado pelo fator de equivalência.

$$
B M=\left(\frac{\text { DQOácidos+DQOCH }}{\text { DQOs efl }}\right) 100 \text { (Eq. 1) }
$$

Na Tabela 4.9 são apresentadas as massas moleculares, reações de oxidação e fatores de equivalência para os metabólitos determinados nos sistemas, sendo eles: ácido cítrico, ácido lático, ácido fórmico, ácido acético, ácido propiônico, ácido butírico e carboidratos. 
Tabela 4.9 - Fatores de equivalência dos ácidos e carboidratos em termos de DQO

\begin{tabular}{cccc}
\hline Composto & Massa molar $\left(\mathbf{g ~ m o l}^{-\mathbf{1}}\right)$ & Reação de oxidação & Fator de equivalência \\
\hline Ácido cítrico $\left(\mathrm{C}_{6} \mathrm{H}_{8} \mathrm{O}_{7}\right)$ & 191,99 & $\mathrm{C}_{6} \mathrm{H}_{8} \mathrm{O}_{7}+4,5 \mathrm{O}_{2} \rightarrow 6 \mathrm{CO}_{2}+4 \mathrm{H}_{2} \mathrm{O}$ & $0,75 \mathrm{gDQO} \mathrm{g}^{-1}$ ac. cítrico \\
\hline Ácido lático $\left(\mathrm{C}_{3} \mathrm{H}_{6} \mathrm{O}_{3}\right)$ & 126,03 & $\mathrm{C}_{3} \mathrm{H}_{6} \mathrm{O}_{3}+3 \mathrm{O}_{2} \rightarrow 3 \mathrm{CO}_{2}+3 \mathrm{H}_{2} \mathrm{O}$ & $0,76 \mathrm{gDQO} \mathrm{g}^{-1} \mathrm{ac}$. lático \\
\hline Ácido fórmico $\left(\mathrm{CH}_{2} \mathrm{O}_{2}\right)$ & 45,99 & $\mathrm{CH}_{2} \mathrm{O}_{2}+0,5 \mathrm{O}_{2} \rightarrow \mathrm{CO}_{2}+3 \mathrm{H} \mathrm{O}$ & $0,35 \mathrm{gDQO} \mathrm{g} \mathrm{gc}^{-1}$ acórmico \\
\hline Ácido acético $\left(\mathrm{C}_{2} \mathrm{H}_{4} \mathrm{O}_{2}\right)$ & 60,05 & $\mathrm{C}_{2} \mathrm{H}_{4} \mathrm{O}_{2}+2 \mathrm{O}_{2} \rightarrow 2 \mathrm{CO}_{2}+2 \mathrm{H}_{2} \mathrm{O}$ & $1,07 \mathrm{gDQO} \mathrm{g}^{-1}$ ac. acético \\
\hline Ácido propiônico $\left(\mathrm{C}_{3} \mathrm{H}_{6} \mathrm{O}_{2}\right)$ & 74,08 & $\mathrm{C}_{3} \mathrm{H}_{6} \mathrm{O}_{2}+3,5 \mathrm{O}_{2} \rightarrow 3 \mathrm{CO}_{2}+3 \mathrm{H}_{2} \mathrm{O}$ & $1,51 \mathrm{gDQO} \mathrm{g}^{-1}$ ac. propiônico \\
\hline Ácido butírico $\left(\mathrm{C}_{4} \mathrm{H}_{8} \mathrm{O}_{2}\right)$ & 88,11 & $\mathrm{C}_{4} \mathrm{H}_{8} \mathrm{O}_{2}+5 \mathrm{O}_{2} \rightarrow 4 \mathrm{CO}_{2}+4 \mathrm{H}_{2} \mathrm{O}$ & $1,82 \mathrm{gDQO} \mathrm{g}^{-1}$ ac. butírico \\
\hline Carboidratos $\left(\mathrm{C}_{12} \mathrm{H}_{22} \mathrm{O}_{11}\right)$ & 342,3 & $\mathrm{C}_{12} \mathrm{H}_{22} \mathrm{O}_{11}+12 \mathrm{O}_{2} \rightarrow 12 \mathrm{CO}_{2}+11 \mathrm{H}_{2} \mathrm{O}$ & $1,12 \mathrm{gDQO} \mathrm{g}^{-1} \mathrm{CH}$ \\
\hline
\end{tabular}




\subsubsection{Análise estatística}

Para comparação do desempenho dos reatores produtores de metano (ASTBR - M II e ASTBR - M I) foi realizada análise estatística por meio do teste de hipótese $\mathrm{t}$ de Student. O principal objetivo foi avaliar a diferença estatística entre as médias dos parâmetros analisados: DQOt, DQOs, CHt, AI/Ap, VBG, PVM, VMM e MY.

O teste foi realizado com auxílio do programa Excel®. Os critérios adotados foram: Nível de significância: $\alpha=0,05$; bicaudal: considerando os pontos críticos $-\mathrm{t}_{\alpha / 2}$ e $\mathrm{t}_{\alpha / 2}$; análise heterocedástica: variação desigual de duas amostras.

As hipóteses analisadas foram:

- $\quad$ H0: Não existe diferença estatística entre as médias $(\mu=\mu 0)$;

- $\quad$ H1: Existe diferença estatística entre as médias $(\mu \neq \mu 0)$.

Assim, foi obtido o valor- $p$ e comparou-se com o nível de significância admitido. Caso o valor $-p$ seja menor que $\alpha$ rejeita-se H0, e se o valor $-p$ for maior que $\alpha$, se aceita H0.

\subsection{Análises de biologia molecular}

Análises de biologia molecular foram realizadas na fase final dos sistemas ASTBR - A (TDH de 4 horas e COV de $60 \mathrm{~g} \mathrm{~L}^{-1} \mathrm{~d}^{-1}$ ), ASTBR - M II (TDH de 24 horas, COV $10 \mathrm{~g}$ $\mathrm{L}^{-1} \mathrm{~d}^{-1}$ e $\left.1 \mathrm{gNaHCO}_{3} \mathrm{~g}^{-1} \mathrm{DQO}\right)$ e ASTBR - M I (TDH de 28 horas, COV $10 \mathrm{~g} \mathrm{~L}^{-1} \mathrm{~d}^{-1}$ e 1 $\mathrm{gNaHCO}_{3} \mathrm{~g}^{-1} \mathrm{DQO}$ ) para comparar as comunidades microbianas aderidas no material suporte e suspensa na fase líquida. A comunidade microbiana do reator acidogênico foi identificada a partir do sequenciamento da região V4 do gene $16 \mathrm{~S}$ do RNAr utilizando a plataforma Ion Torrent. As populações de bactérias e arquéias dos reatores metanogênicos foram comparadas utilizando reação em cadeia da polimerase e eletroforese em gel de gradiente desnaturante (PCR/DGGE).

\subsubsection{Extração do DNA total}

A extração do DNA total das amostras foi realizada utilizando fenol e clorofórmio de acordo com o protocolo de GRIFFITHS et al. (2000) modificado pela lise mecânica em vórtex utilizando pérolas de vidro (150-212 $\mu \mathrm{m}$ Sigma). A qualidade do DNA extraído foi 
verificada por eletroforese em gel de agarose $(1,2 \%)$ em tampão Tris-Acetato-EDTA $1 X$ (Tris $1 \mathrm{x}-4,84 \mathrm{~g}$ Tris, $1,14 \mathrm{~mL}$ ácido acético e 0,74 g EDTA para $1 \mathrm{~L}$ de $d \mathrm{H} 2 \mathrm{O}$ ) corado com Blue Green Loading Dye I, de acordo com as instruções do fabricante.

\subsubsection{Reação em Cadeia da Polimerase (PCR)}

A região V6 do gene 16S do rRNA bacteriano foi amplificada utilizando os primers 968 FGC-1401 R (NUBEL et al., 1996) nas seguintes condições: Pré-desnaturação a $95^{\circ}$ por 7 minutos; 45 segundos de desnaturação a $94^{\circ} \mathrm{C}$; Anelamento por 45 segundos a $56^{\circ} \mathrm{C}$; Extensão por 1 minuto a $72^{\circ} \mathrm{C}$; extensão final por 10 minutos também a $72^{\circ} \mathrm{C}$; e por fim resfriamento a $4^{\circ} \mathrm{C}$. Para o domínio Archaea a PCR foi realizada utilizando os primers 1100 FGC e 1400 R (NUBEL et al., 1996) nas seguintes condições: Pré- desnaturação a $94^{\circ} \mathrm{C}$ por 5 minutos; 1 minuto de desnaturação a $94^{\circ} \mathrm{C}$; Anelamento por 1 minuto a $55^{\circ} \mathrm{C}$; extensão por 1 minuto a $72^{\circ} \mathrm{C}$; Extensão final por 7 minutos a $72{ }^{\circ} \mathrm{C}$; e resfriamento a $4{ }^{\circ} \mathrm{C}$. Para as etapas de desnaturação, anelamento e extensão foram realizados 35 ciclos para os dois domínios analisados. Os produtos das PCR foram separados por meio de eletroforese em gel de agarose 1,2\% e o DNA foi visualizado por coloração com SYBR-Green usando como padrão de tamanho o marcador Low DNA Mass Ladder (Invitrogen).

\subsubsection{Eletroforese em gel com gradiente desnaturante (DGGE)}

Após a amplificação dos genes 16S rRNA foi realizada a técnica de eletroforese em gel com gradiente desnaturante (DGGE). Inicialmente os produtos da PCR foram aplicados em um gel de poliacrilamida com um gradiente linear desnaturante (ureia e formamida) de $45 \%$ a $65 \%$. A eletroforese foi realizada em 75 Volts a $60^{\circ} \mathrm{C}$ por 16 horas. Em seguida a imagem foi capturada em equipamento Eagle Eye II (Stratagene, La Jolla, CA, USA) com iluminação UV. O perfil de bandas do DGGE foi analisado e o dendograma de similaridade foi obtido usando o software BioNumerics V.3.5. Para análise do índice de diversidade de Shannon (H) e Dominância (D) foi utilizado o software Past V.3.06.

\subsubsection{Sequenciamento}

O sequenciamento das amostras do reator acidogênico foi realizado utilizando a plataforma Ion Torrent no instituto de pesquisas biológicas estáveis Clemente (Montevideo-Uruguai). Para tanto, foram enviadas amostras de DNA genômico em 
concentração mínima de $10 \mathrm{ng} / \mu \mathrm{L}$ e pureza (relação 260/280) de 1,8 determinados em espectrofotômetro Nanodrop 2000. A integridade do DNA foi verificada por eletroforese em gel de agarose (1,2 \%) em TAE 1X. A amplificação da região V4 do gene rRNA 16S, foi realizada por PCR utilizando os primers 520F (AYTGGGYDTAAAGNG) e 802R (TACNVGGGTATCTAATCC) gerando fragmentos de tamanho médio de $347 \mathrm{pb}$ (RDP's Pyrosequencing Pipeline: http://pyro.cme.msu.edu/pyro/help.jsp). A integridade dos produtos do PCR foi verificada em gel de agarose (1,8\%). As sequencias foram analisada utilizando as ferramentas disponíveis no RDP (COLE et al., 2014). Foram ainda realizadas analises dos dados brutos utilizando o software QIIME (CAPORASO et al., 2010) versão 1.9.1. A qualidade das bases sequenciadas consistiu em um comprimento mínimo de 200 pb e critério de qualidade $\mathrm{Q}>25$. A remoção de quimeras foi realizada usando USEARCH6.1 (EDGAR, 2010). As OTUs foram agrupadas por similaridade de 97\%. As sequencias foram alinhadas pelo algoritmo de PyNAST (CAPORASO et al., 2010). Atribuições taxonômicas foram realizadas usando o algoritmo Uclast (EDGAR, 2010) usando o conjunto de dados de referência rRNA 16S do banco de dados Greengenes (DESANTIS et al., 2006). As sequências foram depositadas no NCBI com o número de acesso SRP133770. 


\section{RESULTADOS E DISCUSSÃO}

\subsection{Desempenho do reator acidogênico $(\mathrm{ASTBR}-\mathrm{A})$}

$\mathrm{O}$ reator ASTBR - A foi operado com pH afluente médio de 6,30 $\pm 0,30$, sem adição de alcalinizante, e pH efluente de 3,80 \pm 0,14 (Figura 5.1). O pH efluente foi abaixo do $\mathrm{pH}$ característico de sistemas fermentativos aplicados para a produção de hidrogênio $(\mathrm{pH}=5,5)$. FERRAZ JR. et al. (2014) e FUESS et al. (2016) relataram que a produção de hidrogênio a partir da vinhaça em $\mathrm{pH}$ abaixo de 5,0 ou maior que 5,3 pode causar impacto negativo na produção de hidrogênio. ZOETEMEYER et al. (1982) avaliaram a influência do $\mathrm{pH}$ na acidogênese, verificando que $\mathrm{pH}$ entre 5,7 e 6,0 é ideal para uma melhor estabilidade do reator metanogênico combinado ao acidogênico. HAN et al. (2012) em condições mesofílicas $\left(35^{\circ} \mathrm{C}\right), \operatorname{COV} 32 \mathrm{~g} \mathrm{~L}^{-1} \mathrm{~d}^{-1}$ e $\mathrm{TDH}$ de 6 horas obtiveram produção continua de $\mathrm{H}_{2}$ com um pH efluente de 4,5 utilizando como substrato o melaço de cana-deaçúcar.

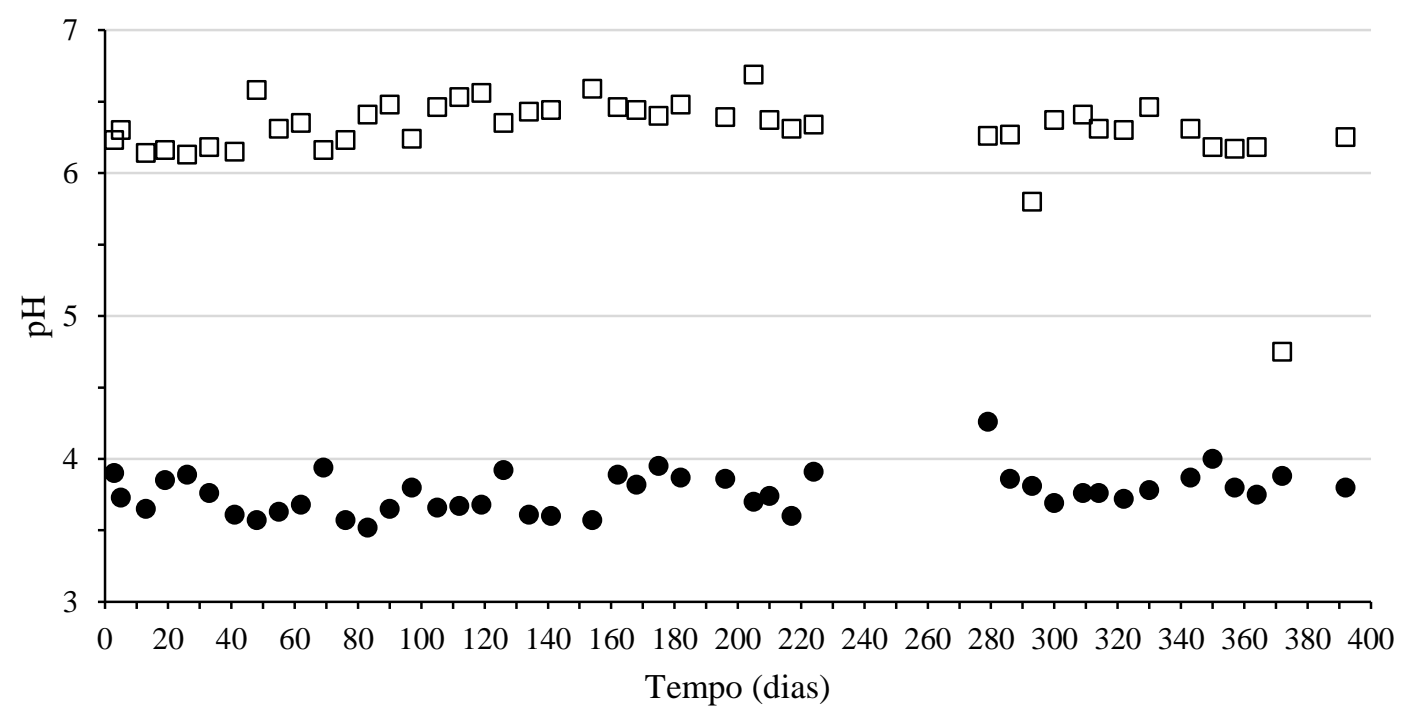

Figura 5.1 - Variação do pH afluente e efluente do reator ASTBR - A. Legenda: - $\square-$ pH afluente.

-๑- pH efluente

A remoção de matéria orgânica, expressa na forma de DQOt, e a conversão de carboidratos são apresentadas na Figura 5.2 A e B, respectivamente. A eficiência de remoção de matéria orgânica sofreu alterações durante o período de operação, sendo a média de remoção da DQOt de 6,40 \pm 6,10\% e da DQOs de 6,30 \pm 7,20\%. Em relação aos CHt houve conversão de 40,40 $\pm 14,30 \%$ e CHs de 42,10 $\pm 15,30 \%$. A remoção de matéria orgânica em sistemas acidogênicos é consideravelmente menor do que nos 
tradicionais processos anaeróbios metanogênicos. A matéria orgânica é convertida em ácidos (acético, butírico, lático) pelas bactérias fermentativas acidogênicas, que constituem a matéria orgânica determinada do meio líquido. A baixa remoção de matéria orgânica nesse sistema não pode ser caracterizada como um problema, já que é uma característica da fase ácida (FERNANDES et al., 2010). WANG et al. (2013), estudaram o efeito do TDH na produção de $\mathrm{H}_{2}$ a partir do melaço de cana-de-açúcar, analisando cinco tempos de detenção hidráulico que variaram entre 4 a 10 horas em um reator CSTR com volume de $6 \mathrm{~L}, \mathrm{pH}$ variando entre 4,3 - 4,4 e DQO de $8 \mathrm{~g} \mathrm{~L}^{-1}$. Entre todos os TDHs estudados, o que apresentou melhor eficiência na produção de hidrogênio foi o de 5 horas, com 12,27 mmol $\mathrm{H}_{2} \mathrm{~L}^{-1} \mathrm{~h}^{-1}$. Nesse estudo a remoção de DQO ficou entre 31,6 e $39,2 \%$.
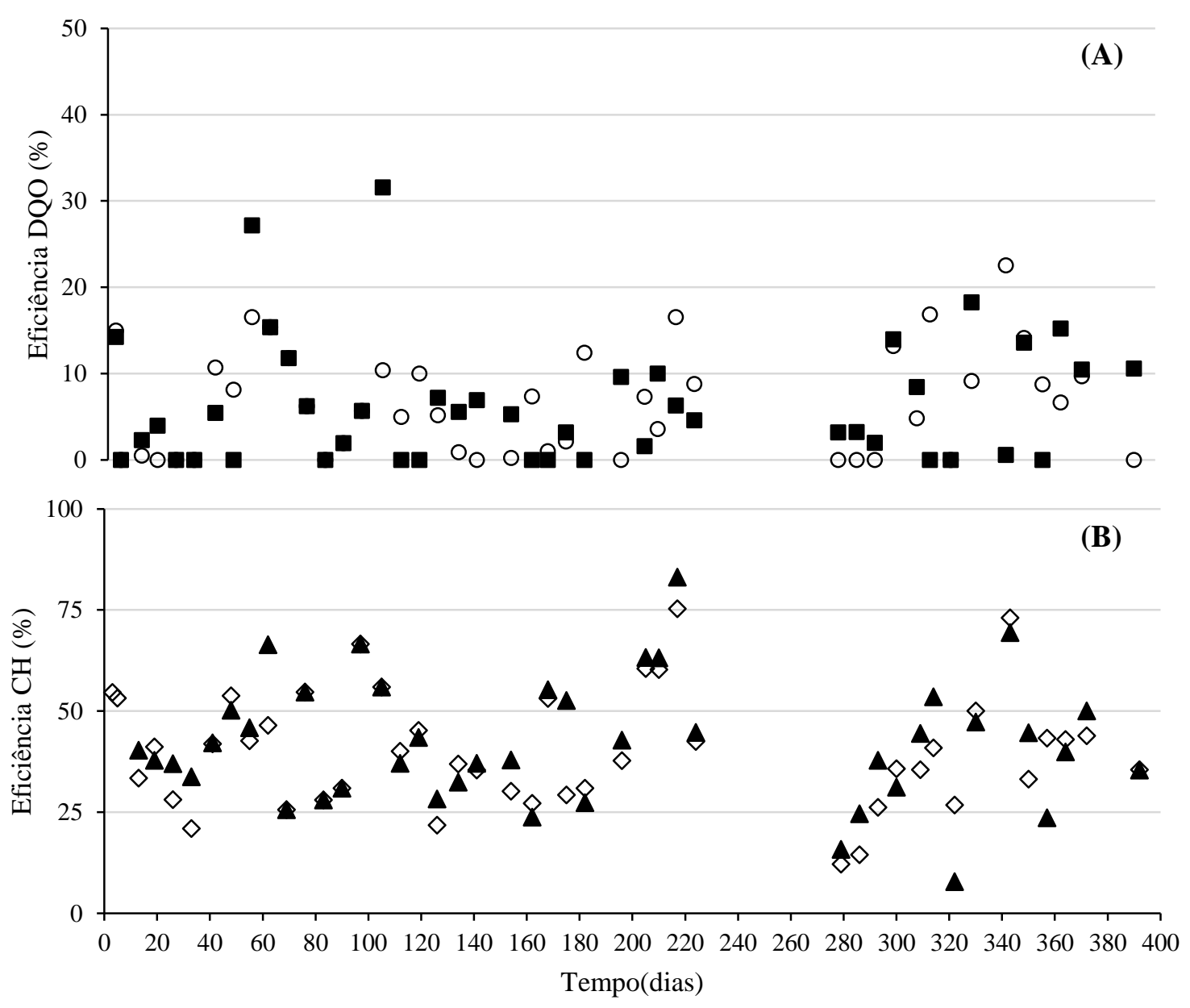

Figura 5.2 - (A)Variação temporal da eficiência de remoção de matéria orgânica; (B) variação temporal de conversão de carboidratos no reator ASTBR - A. Legenda: - - - Remoção de DQOt (\%); - - - remoção de DQOs (\%); - - Conversão de CHt (\%); - $\mathbf{\Delta}$ - Conversão de CHs (\%) 
Durante o $224^{\circ}$ e $279^{\circ}$ dia de operação a alimentação do sistema foi interrompida. Pela Figura 5.2B nota-se que no $217^{\circ}$ dia houve o maior rendimento na conversão de $\mathrm{CHt}$, chegando em 83,00\% de CHs e 75,30\% CHt. Ao reiniciar o sistema houve uma queda no rendimento na conversão de $\mathrm{CHt}$, entretanto o sistema se recuperou, retornando à eficiência de $69,40 \%$ de $\mathrm{CHs}$ e $73,00 \% \mathrm{CHt}$ no $343^{\circ}$ dia de operação.

\subsubsection{Produção de hidrogênio}

A composição do biogás (Figura 5.3) apresentou valor médio de $\mathrm{H}_{2}$ de $51 \pm 13 \%$, enquanto que para o $\mathrm{CO}_{2}$ o valor encontrado foi de $49 \pm 13 \%$, e os gases $\mathrm{N}_{2}$ e $\mathrm{CH}_{4}$ não apresentaram valores significativos, indicando que o sistema estava adequado para realização da acidogênese. REN et al. (2006), em um reator em escala piloto produzindo hidrogênio a partir da fermentação anaeróbia do melaço de beterraba, encontraram valores de $\mathrm{H}_{2}$ no biogás entre 40 e $52 \%$, utilizando COV entre 3,1 e $85,6 \mathrm{~kg} \mathrm{DQO} \mathrm{m}^{-3}$ reator $\mathrm{d}^{-1}$. Assim, os valores encontrados estão similares a esse estudo.

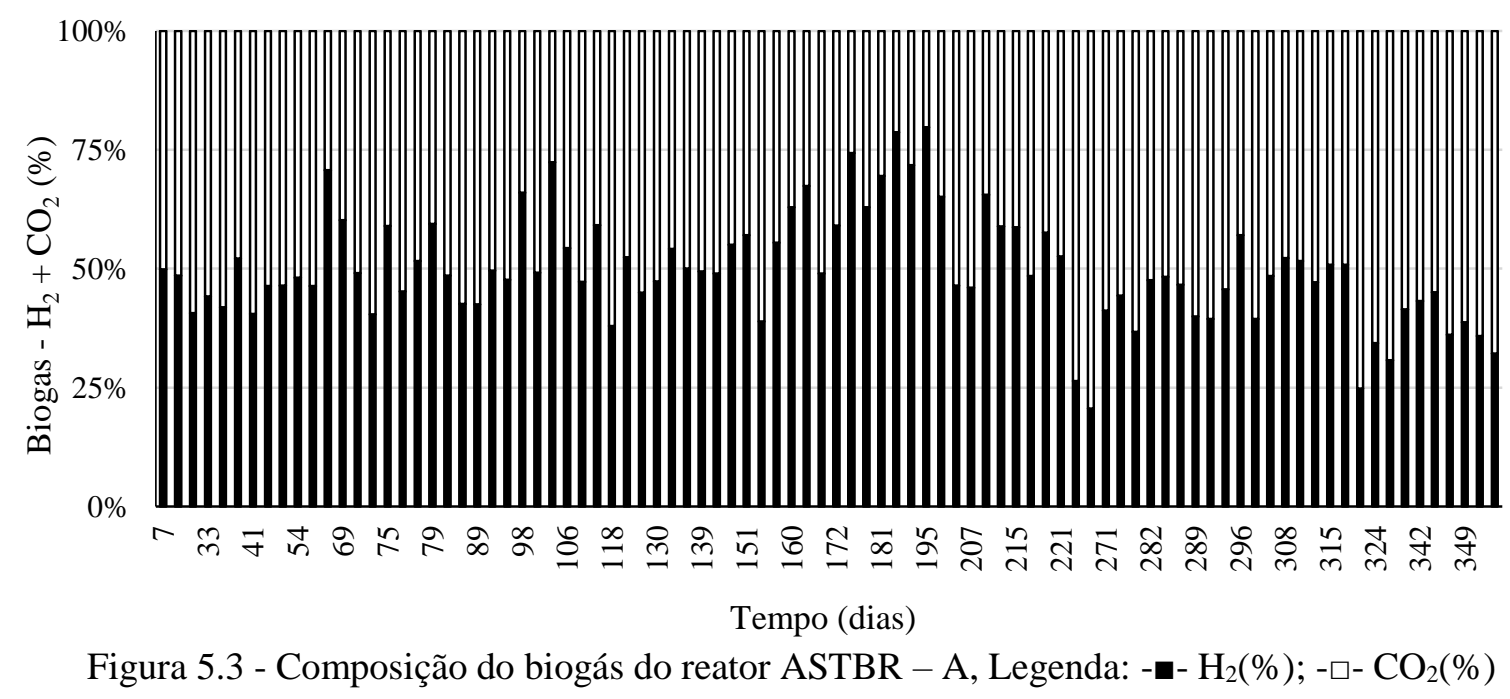

A vazão de biogás (VBG) foi de $291 \pm 132 \mathrm{~mL} \mathrm{~h}^{-1}$ (Figura 5.4A), a produção volumétrica de $\mathrm{H}_{2}(\mathrm{PVH})$ durante o período de operação foi de $88 \pm 47 \mathrm{~mL} \mathrm{H}_{2} \mathrm{~L}^{-1} \mathrm{~h}^{-1}$ (Figura 5.4B). Em relação ao rendimento (HY), a média foi de $1,18 \pm 0,72 \mathrm{~mol} \mathrm{H}_{2} \mathrm{~mol}$ $\mathrm{CH}^{-1}$ (Figura 5.4C), correspondendo a um potencial energético de $2,51 \mathrm{~kJ} \mathrm{~L} \mathrm{~L}^{-1}$ $\left(0,21 \mathrm{~kJ} \mathrm{~g}^{-1}\right.$ melaço $)$. Observou-se aumento contínuo na produção de $\mathrm{H}_{2}$ até o $224^{\circ}$ dia de operação, porém após o $279^{\circ}$ dia de operação, quando foi retomada a alimentação do sistema, após período de interrupção para recesso a PVH retornou abaixo do $50 \mathrm{mLH}_{2} \mathrm{~L}^{-1} \mathrm{~h}^{-1}$, retornando aos valores próximos aos anteriores em 27 dias. WU et al. 
(2006) estudaram produção de $\mathrm{H}_{2}$ a partir da fermentação de 4 gDQO L ${ }^{-1}$ de sacarose e TDH de 4 horas em um reator anaeróbio em agitação constante. Os autores obtiveram 2,40 \pm 0,07 $\mathrm{molH}_{2} \mathrm{~mol}^{-1}$ sacarose, e proporção de 39,50 $\pm 1,30 \%$ de $\mathrm{H}_{2}$ no biogás, valores semelhantes aos encontrados nesse estudo para um mesmo TDH.
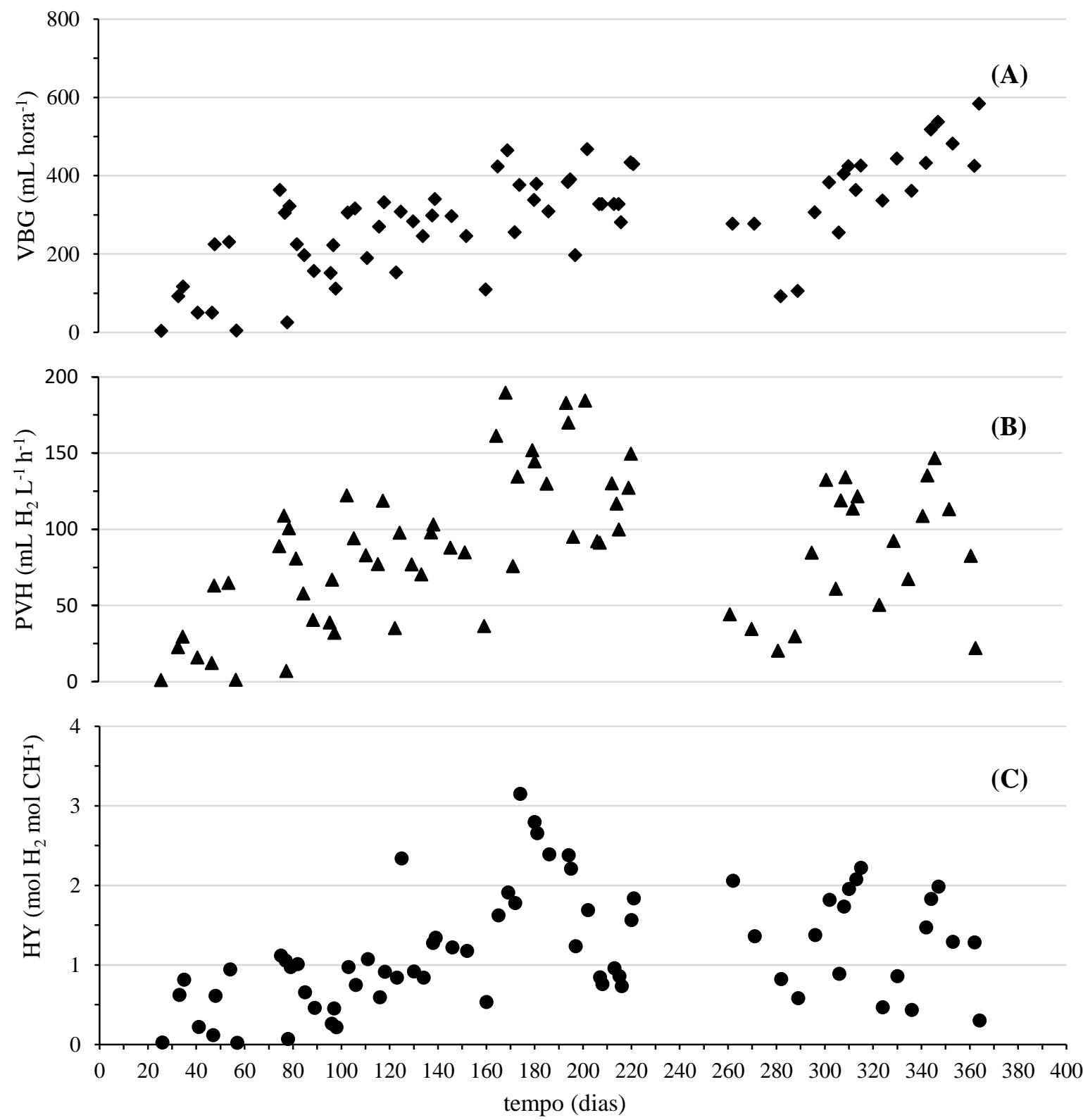

Figura 5.4 - (A) Vazão de biogás; (B) Produção volumétrica de $\mathrm{H}_{2}$; (C)Rendimento de $\mathrm{H}_{2}$ no reator ASTBR - A

FUESS et al. (2016) avaliaram as estratégias operacionais para manter taxas continuas na produção de $\mathrm{H}_{2}$ em reatores APBR operados com vinhaça de cana-de-açúcar. Os autores concluíram que a descarga periódica da biomassa acumulada, o controle contínuo do pH efluente e a aplicação de elevadas cargas orgânicas são essenciais para a 
produção contínua. No presente trabalho não houve controle de $\mathrm{pH}$, nem descartes de biomassa, sendo a concentração de SSV no efluente ao longo de toda operação de $154 \pm$ $39 \mathrm{mg} \mathrm{SSV} \mathrm{L}{ }^{-1}$. Entretanto, a manutenção da produção de $\mathrm{H}_{2}$ se deu no período de 392 dias de operação do ASTBR - A. A elevada COV, de $60 \mathrm{~g} \mathrm{~L}^{-1}$, e o baixo pH possivelmente estiveram associados ao bom desempenho e ao longo período de operação do sistema.

\subsubsection{Avaliação dos produtos intermediários}

A composição do melaço em termos de ácidos orgânicos que compõem a matéria orgânica, quantificada como $10 \mathrm{gDQO} \mathrm{L}{ }^{-1}$ foram: Ácido cítrico $\left(758 \pm 74 \mathrm{mg} \mathrm{L}^{-1}\right)$, ácido lático (158 $\left.\pm 7 \mathrm{mg} \mathrm{L}^{-1}\right)$, ácido fórmico $\left(361 \pm 35 \mathrm{mg} \mathrm{L}^{-1}\right)$ e ácido propiônico $\left(389 \pm 40 \mathrm{mg} \mathrm{L}^{-1}\right)$. Em relação aos carboidratos foram: Glicose $\left(2472 \pm 89 \mathrm{mg} \mathrm{L}^{-1}\right) \mathrm{e}$ frutose $\left(664 \pm 102 \mathrm{mg} \mathrm{L}^{-1}\right)$.

Em relação aos metabólitos da fermentação do melaço (Figura 5.5), os principais ácidos encontrados no sistema ao longo da operação foram: Ácido cítrico (251 $\left.\pm 171 \mathrm{mg} \mathrm{L}^{-1}\right)$, ácido lático $\left(332 \pm 263 \mathrm{mg} \mathrm{L}^{-1}\right)$, ácido fórmico $\left(99 \pm 51 \mathrm{mg} \mathrm{L}^{-1}\right)$, ácido acético $\left(209 \pm 170 \mathrm{mg} \mathrm{L}^{-1}\right)$, ácido propiônico $\left(28 \pm 74 \mathrm{mg} \mathrm{L}^{-1}\right)$ e ácido butírico $(225 \pm 99$ $\left.\mathrm{mg} \mathrm{L}^{-1}\right)$.

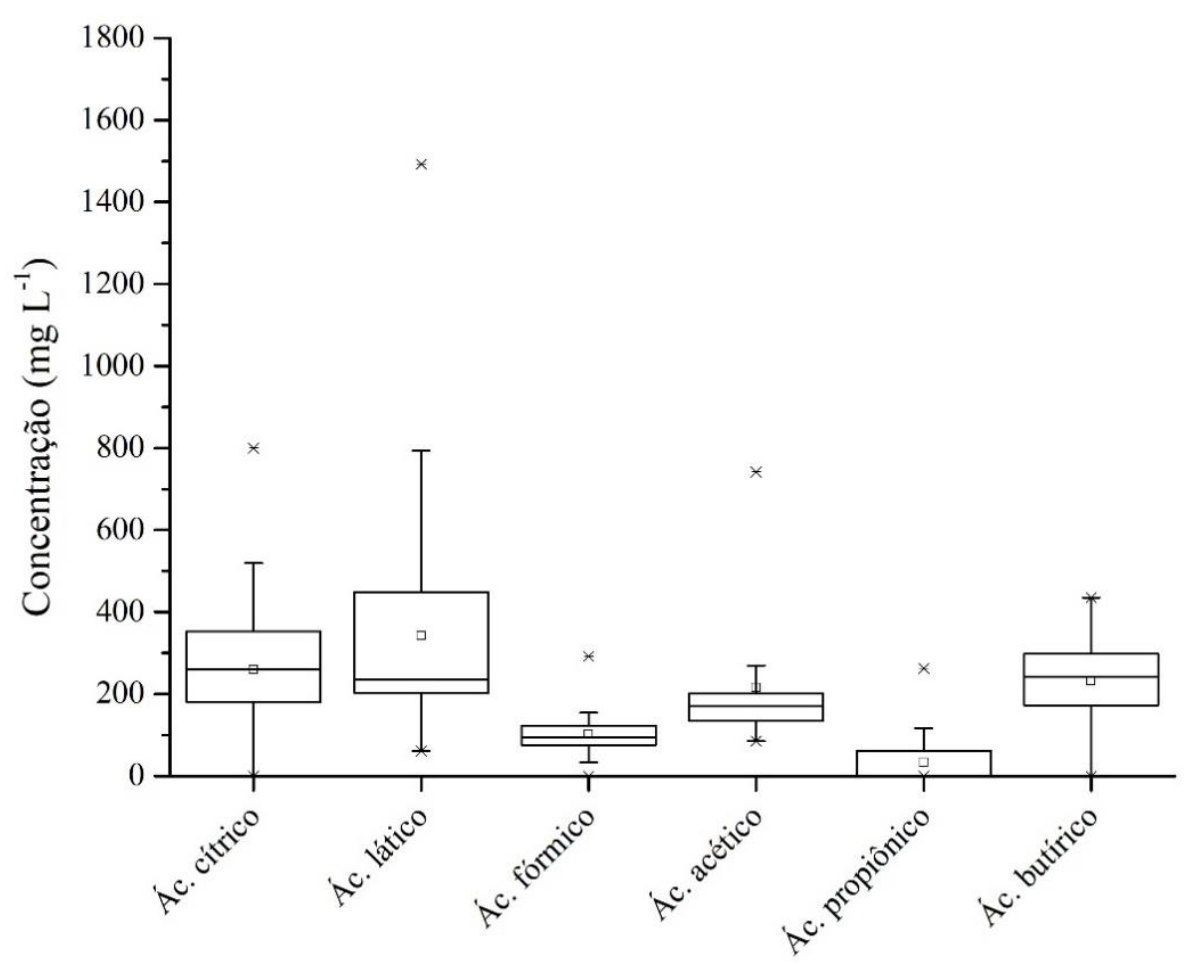

Figura 5.5 - Box-plot da concentração dos metabólitos do reator ASTBR - A 
Com base na produção de metabólitos ao longo da operação do reator (Figura 5.6) verificou-se que até o $136^{\circ}$ dia houve predominância do ácido cítrico $(19,16 \pm 3,90 \%)$ e lático $(28,63 \pm 6,86 \%)$ no sistema. Entre o $136^{\circ}$ e $224^{\circ}$ dia operação houve uma queda na produção do ácido cítrico $(1,26 \pm 1,28 \%)$ e do ácido lático $(13,84 \pm 4,05 \%)$, ocorrendo um aumento na proporção do ácido butírico de $27,73 \pm 9,08 \%$ para $57,35 \pm 6,39 \%$. A partir do $279^{\circ}$ o ácido cítrico voltou a ser produzido no sistema na proporção de $18,87 \pm 6,20 \%$, o ácido lático diminui para $13,00 \pm 1,42 \%$, enquanto que o ácido butírico permaneceu em 45,75 $\pm 5,95 \%$. Os demais metabólitos produzidos, como ácido fórmico e acético mantiveram-se estáveis ao longo da operação, com proporção de 3,02 \pm 0,81\% e 18,00 \pm $4,00 \%$, respectivamente. A produção do ácido propiônico foi detectada apenas em alguns períodos, com valor médio durante o período operacional de $3,23 \pm 4,30 \%$. A Manutenção da baixa concentração de ácido propiônico nos sistemas acidogênicos para produção de $\mathrm{H}_{2}$ é de grande relevância, pois a formação desse ácido ocorre com o consumo de $\mathrm{H}_{2}$ do sistema (reação 3, item 3.6).

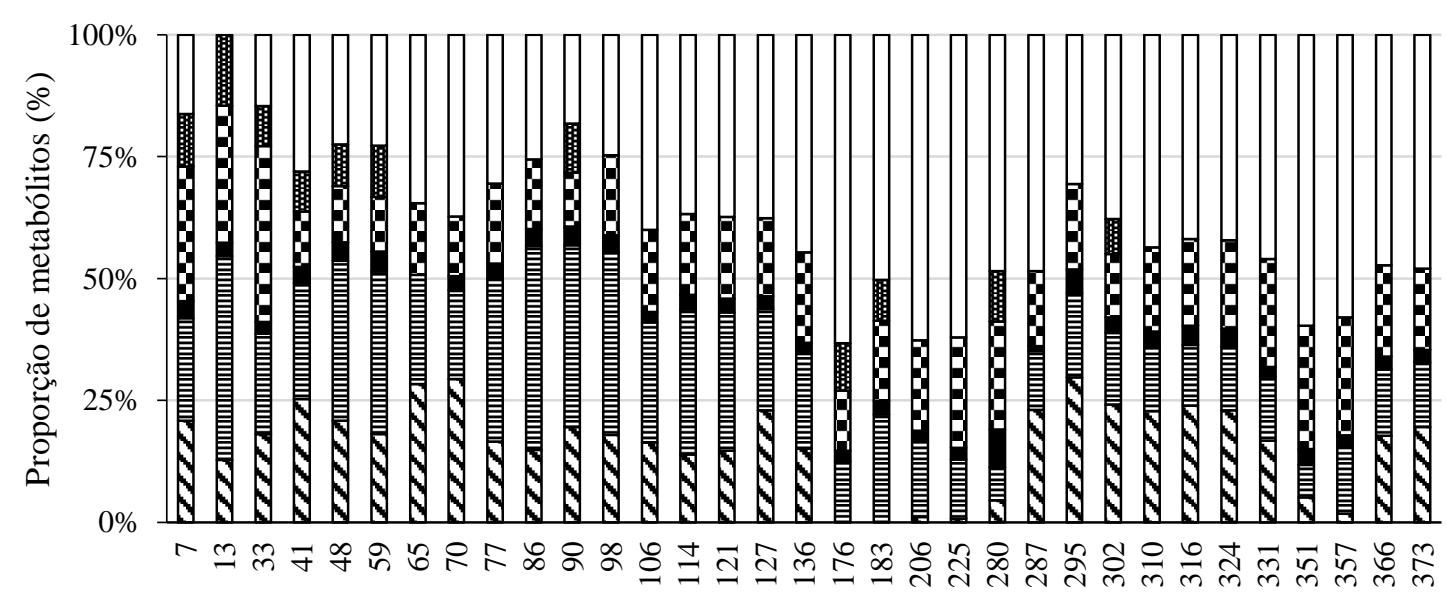

Tempo(dias)
$\mathbf{\nabla}$ Ácido cítrico
目 Ácido lático
- Ácido fórmico
口Ácido Acético
四 Ácido Propiônico
$\square$ Ácido Butírico

Figura 5.6 - Proporção dos metabólitos da fermentação na fase solúvel do reator ASTBR - A

A partir do monitoramento realizado ao longo da operação do sistema ASTBR-A foi possível realizar o balanço de massa em termos de DQOs (Figura 5.7). 


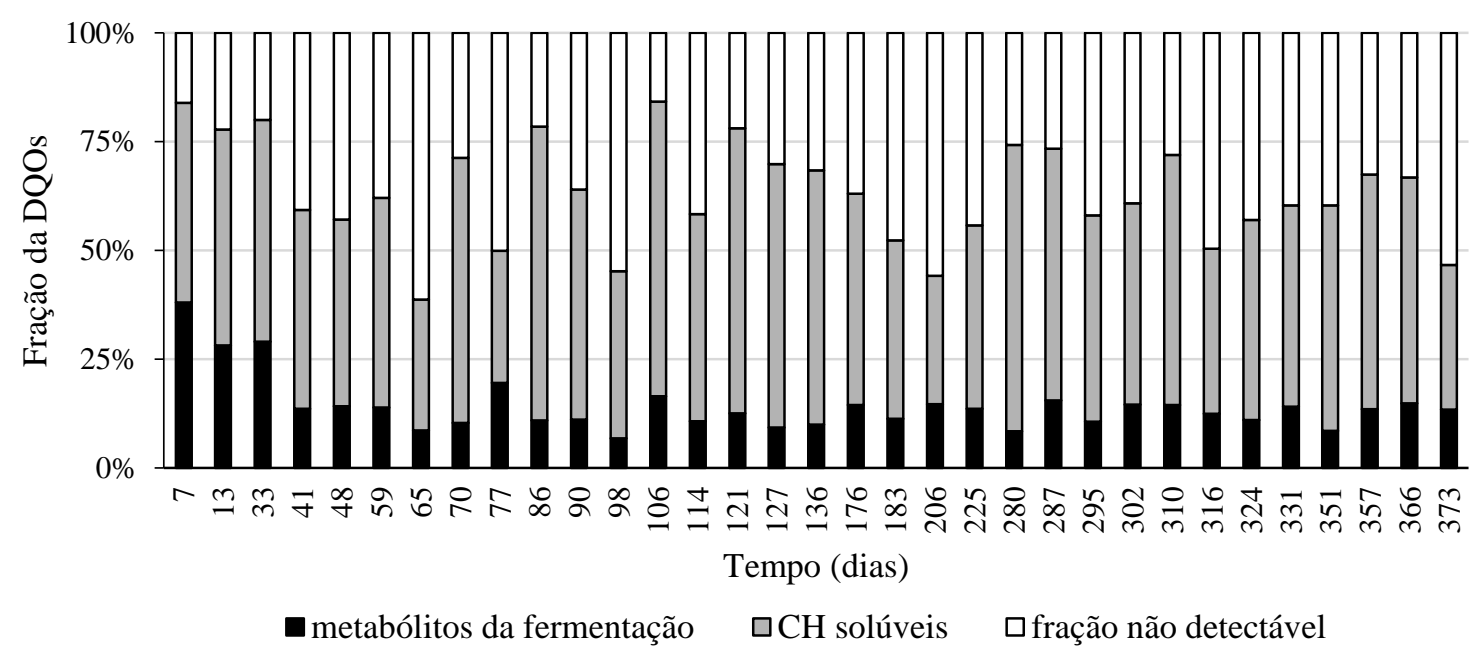

Figura 5.7 - Balanço de massa para a fase solúvel do efluente do reator ASTBR - A.

Em relação à proporção da DQOs medida, $14 \pm 4 \%$ corresponde a metabólitos da fermentação, $49 \pm 8 \%$ aos $\mathrm{CHs}$, e os demais $37 \pm 10 \%$ à fração não detectável pelos métodos utilizados, como por exemplo a melanoidina (MARTINS; KITTINYA; OJIJO, 2011), responsável pela coloração escura do melaço.

\subsubsection{Estrutura das comunidades microbianas na fase acidogênica}

A estrutura da comunidade microbiana do reator ASTBR - A foi analisada ao final da operação, onde o sistema possuía TDH de 4 horas e COV $60 \mathrm{~g} \mathrm{~L}^{-1} \mathrm{~d}^{-1}$. Para comparação das comunidades microbianas existentes no sistema foram retiradas amostras da biomassa suspensa (\#1) e da fase aderida (\#2) ao material suporte (espuma de poliuretano) (Figura $5.8)$.
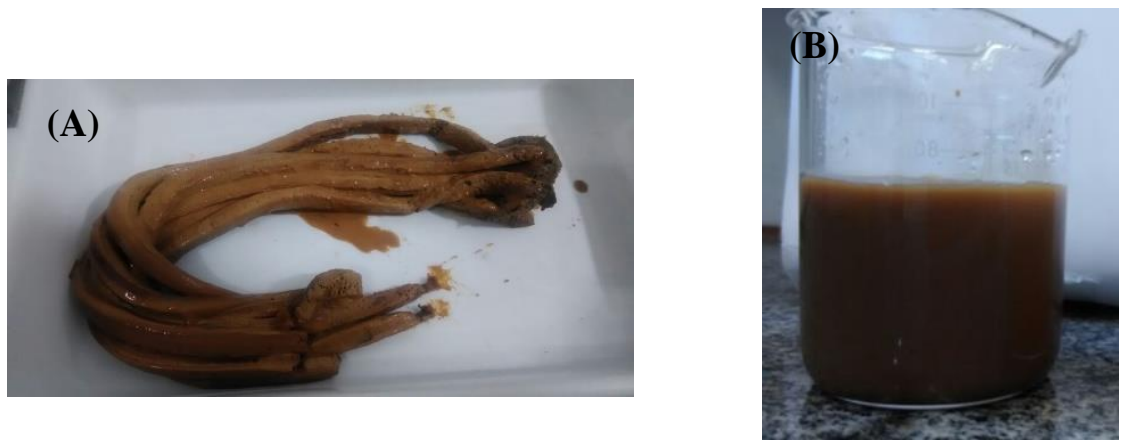

Figura 5.8 Biomassa acidogênica. (A) Espuma de poliuretano com biomassa aderida;(B) Biomassa suspensa 
A caracterização é apresentada em relação à abundância relativa (\%) em termos de gêneros. Na Figura 5.9 são apresentando os gêneros com abundância relativa maior que 0,10\% em pelo menos uma das amostras e as sequências não classificadas em nível de gênero $(0,6$ - 22\%). $\mathrm{O}$ gênero predominante em ambas amostras foi $\mathrm{o}$ Thermoanaerobacterium com $98 \%$ e $71 \%$ para as amostras \#1 e \#2, respectivamente. Para a amostra \#1 os microrganismos encontrados foram: Lactobacillus $(1,10 \%)$, Clostridium (0,25\%), Megasphaera (0,12\%), Pseudomona (0,06\%), Leconostoc $(0,05 \%)$ e Lactococcus $(0,004 \%)$. E para a amostra \#2, considerando os mesmos gêneros da amostra \#1, a abundância relativa foi: Lactobacillus (1,33\%), Clostridium (0,26\%), Megasphaera (0,07\%), Pseudomona (2,50\%), Leconostoc (0,93\%) e Lactococcus $(0,38 \%)$.

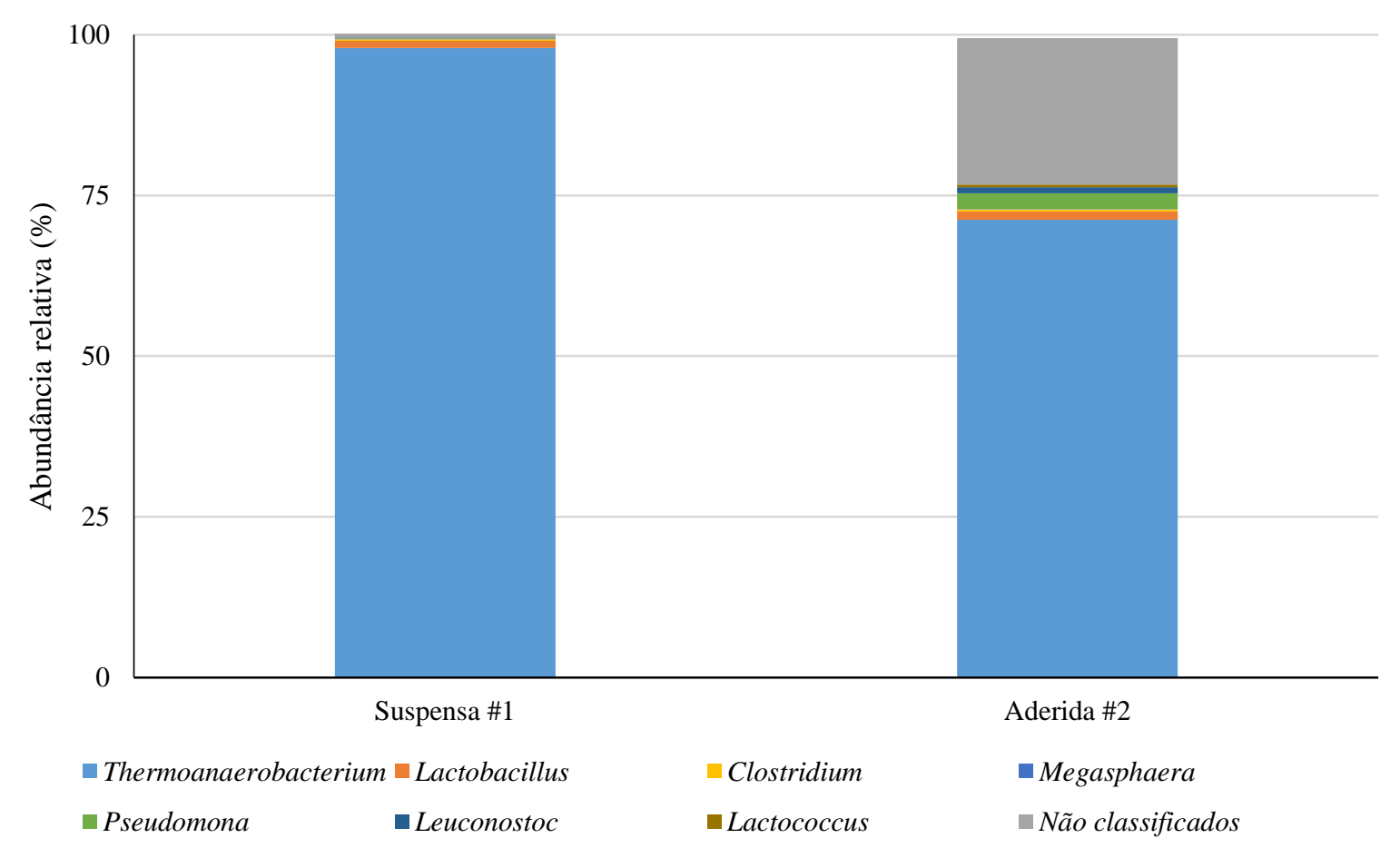

Figura 5.9 - Abundância relativa do principais gêneros na biomassa suspensa e aderida do reator ASTBR - A

Os organismos predominantes no sistema - Thermoanaerobacterium - são anaeróbios estritos, e bactérias gram-positivas (FERRAZ JR. et al., 2014), ou seja, são capazes de formar endósporos e resistir a variações no sistema. $\mathrm{O}$ pH efluente do sistema ASTBR - A encontrava-se em 3,8, o qual é uma condição extrema para alguns microrganismos, e a capacidade de formar endósporos auxilia a sobrevivência nessas condições. Além disso, o gênero Thermoanaerobacterium cresce principalmente na presença de carboidratos facilmente fermentáveis, como os carboidratos existentes no 
melaço de cana-de-açúcar e são capazes de suportar elevadas cargas orgânicas e baixo TDH (O-THONG et al., 2008). Esse organismo foi reportado principalmente em sistemas termofílicos $\left(50^{\circ} \mathrm{C}-70^{\circ} \mathrm{C}\right)$, e convertem os carboidratos a hidrogênio a partir de metabólitos como ácido acético, butírico e lático (O-THONG et al., 2008; KONGJAN et al., 2011; FERRAZ JR. et al., 2015; FUESS et al., 2018).

FERRAZ JR.; ETCHEBEHERE; ZAIAT (2015) encontraram uma abundância relativa entre $7,2-8,1 \%$ para o gênero Thermoanarobacterium, em um reator termofílico de leito fixo empacotado (APBR) alimentado com vinhaça de cana-de-açúcar (COV de

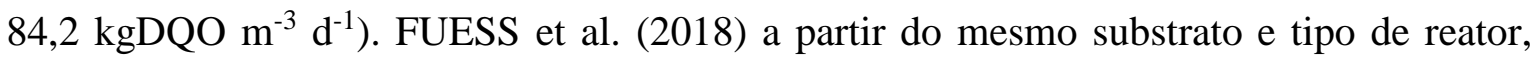
relataram abundância entre 1,2-9,3\% para esse gênero, a uma temperatura de $55^{\circ} \mathrm{C}$ e COV 84,2 $\mathrm{kgDQO} \mathrm{m}^{-3} \mathrm{~d}^{-1}$. VILELA (2017) utilizando um reator ASTBR material suporte de

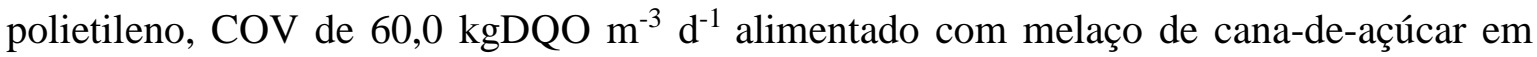
condições termofílicas relatou $47,3 \%$ dos microrganismos do sistema como sendo do gênero Thermoanarobacterium e 26,6\% do gênero Clostridium.

O material suporte apresenta menor susceptibilidade para aderência dos microrganismos do gênero Thermoanarobacterium, uma vez que realizações de descarte de biomassa não favoreceram esse gênero se estabelecer no material suporte (FUESS et al., 2018). Esse fato corrobora com a diferença de $27 \%$ encontrada entre as amostras de biomassa suspensa (\#1) e aderida (\#2) do reator ASTBR - A.

Os gêneros Lactobacillus e Clostridium foram detectados com abundancias relativas semelhantes para as duas amostras, aproximadamente 1\% para Lactobacillus e 0,25\% para Clostridium. A produção e o consumo de hidrogênio podem ser desempenhadas por bactérias do gênero Clostridium (GUO et al., 2014), que são organismos encontrados em condições mesofílicas e termofílicas, e também capazes de resistir a ambientes com ampla faixa de pH (3,6 - 7,0)(WIEGEL et al., 2006).

O gênero Clostridium foi reportado por DIEZ-GONZALEZ et al. (1995); MATSUMOTO; NISHIMURA (2007) como consumidores de ácido lático e acético para produção de ácido butírico e consequentemente $\mathrm{H}_{2}$ (Reação 6). Essa rota metabólica foi constatada no reator ASTBR -A. A Figura 5.10 mostra variação dos ácidos acético, butírico e lático ao longo da operação do sistema em termos de DQO, e a variação do rendimento de $\mathrm{H}_{2}$. É possível notar que o aumento da concentração do ácido butírico e do 
HY coincidem com a queda na concentração do ácido lático e acético. $\mathrm{O}$ máximo rendimento de $\mathrm{H}_{2}$ ocorreu no $176^{\circ}$ dia de operação, com $3,15 \mathrm{~mol} \mathrm{H}_{2} \mathrm{~mol}^{-1} \mathrm{CH}$. Para esse mesmo dia de operação a concentração de ácido lático foi de $154 \mathrm{mg} \mathrm{L}^{-1}$, ácido acético 152 $\mathrm{mg} \mathrm{L} \mathrm{L}^{-1} \mathrm{e}$ de ácido butírico $781 \mathrm{mg} \mathrm{L}^{-1}$.

Os organismos do gênero Leuconostoc e Lactococcus também foram detectados nas amostras, apresentando maior abundância relativa na amostra \#2. Esses microrganismos fazem parte das bactérias produtoras de ácido lático e são muito tolerantes a ambientes ácidos (SIEGUMFELDT; RECHINGER; JAKOBSEN, 2000) como o observado neste estudo ( $\mathrm{pH} \sim 3,8)$.

Em relação ao gênero Pseudomonas houve grande variação na abundância relativa entre amostra \#1 (0,06\%) e amostra \#2 (2,5\%). Essas bactérias são capazes de produzir $\mathrm{H}_{2}$ (KAPDAN; KARGI, 2006), porém não são resistentes a temperaturas maiores de $60^{\circ} \mathrm{C}$, apresentando máximo crescimento em $30^{\circ} \mathrm{C}$ (TSUJI et al., 1982). O gênero Pseudomona é capaz de degradar compostos aromáticos policíclicos (KUMARI et al., 2018) por isso é avaliada para a degradação do composto melanoidina existente no melaço de cana-deaçúcar e responsável pela coloração escura desse substrato, o que prejudica seu tratamento. A Pseudomona fluorescens foi capaz de descolorir $76 \%$ do melaço obtido em uma indústria de açúcar, porém quando imobilizada, apenas $50 \%$ da cor do substrato foi removida (DAHIYA et al., 2001).

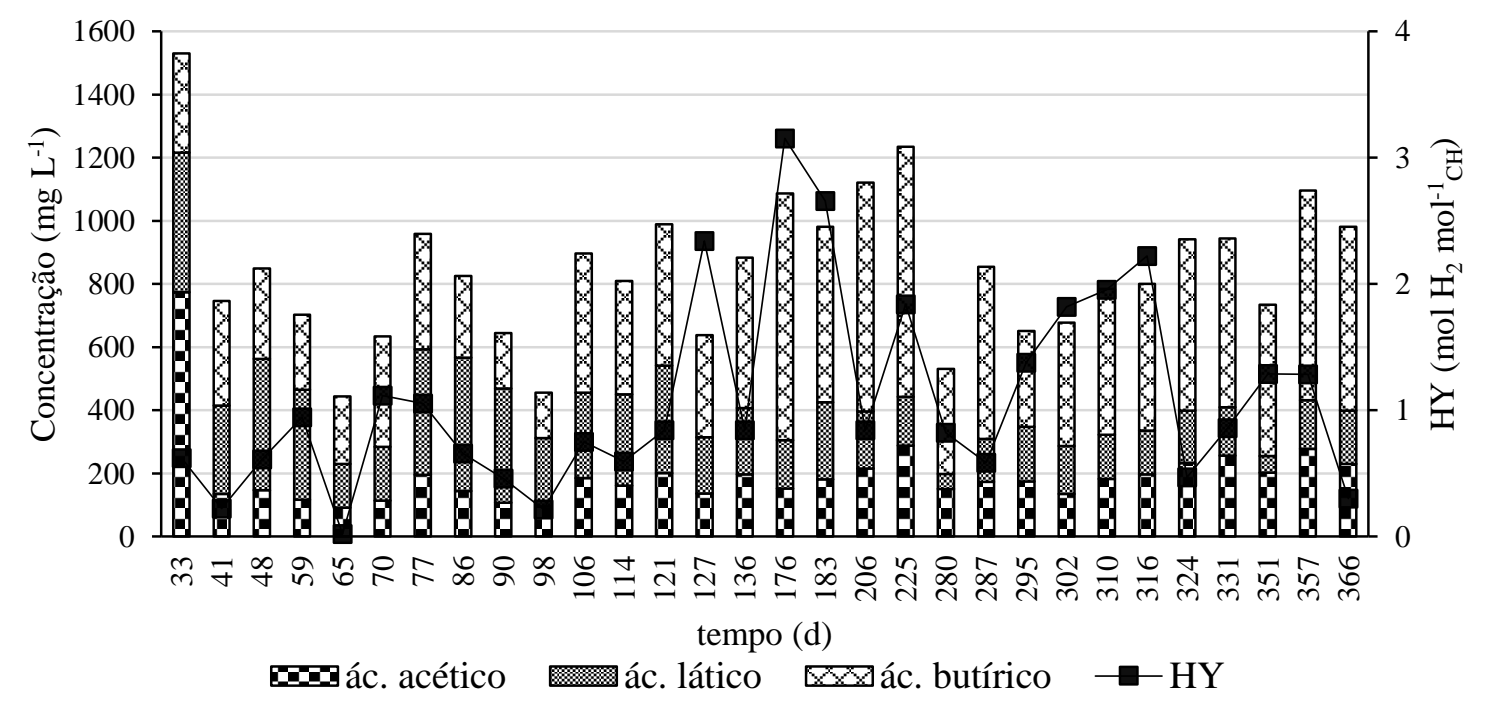

Figura 5.10 Variação temporal do rendimento de H2 de acordo com a geração de ácido acético, lático e butírico 


\subsection{Desempenho do reator metanogênico - sistema de duas fases (ASTBR - M II)}

O reator metanogênico de leito estruturado do sistema de duas fases (ASTBR - M II) foi monitorado por 344 dias. Oito diferentes cargas orgânicas volumétricas foram aplicadas ao ASTBR - M II (entre 0,6 e 10,0 $\mathrm{g} \mathrm{L}^{-1} \mathrm{~d}^{-1}$ ), entretanto, devido à instabilidade do sistema (explicado no item 4.3.2.), entre o $125^{\circ}$ e $274^{\circ}$ houve um decréscimo das cargas orgânicas volumétricas aplicadas ao reator com a finalidade de recuperação do desempenho do mesmo. Ressalta-se que esse reator, em série com o ASTBR - A, desempenhou a digestão anaeróbia completa, uma vez que apenas $40 \%$ dos carboidratos totais eram convertidos no ASTBR - A. Portanto, embora o objetivo do sistema combinado seja a separação de fases da digestão anaeróbia em acidogênese, para geração de ácidos e $\mathrm{H}_{2}$, e metanogênese para remoção da matéria orgânica e produção de $\mathrm{CH}_{4}$, o ASTBR - M II realizou ambas as fases da digestão anaeróbia.

Para melhor compreensão dos dados que serão discutidos nessa seção, deve-se atentar que o sistema ASTBR - M II teve três principais estágios: $1^{\circ}$ correspondente a Fase I (COV de 2,5 $\mathrm{g} \mathrm{L}^{-1} \mathrm{~d}^{-1}$ e TDH de $96 \mathrm{~h}$ ); $2^{\circ}$ aumento gradual da COV de 0,6 a 4,8 $\mathrm{g} \mathrm{L}^{-1} \mathrm{~d}^{-1}$ (Fases II a Va); $3^{\circ}$ Recuperação do desempenho do sistema com o retorno para COV de 2,4 $\mathrm{g} \mathrm{L}^{-1} \mathrm{~d}^{-1}$, seguido pelo posterior do incremento de COV até 10,00 $\mathrm{g} \mathrm{L}^{-1} \mathrm{~d}^{-1}$ (Fases IVb a VIII). O pH afluente se manteve estável ao longo de toda operação, com média de 7,05 \pm 0,31, e o pH efluente de 8,33 \pm 0,83 (Figura 5.11A). FERRAZ JR. et al. (2016) relataram estabilidade de sistema termofílico visando a produção de metano a partir de vinhaça de cana-de-açúcar em pH entre 8,30 e 8,50 e VILELA (2017) com pH efluente de 8,70 em um reator ASTBR utilizando melaço de cana-de-açúcar como substrato. Em relação aos ácidos totais voláteis (Figura 5.11B) realizados por titulação, os valores sofreram variações de acordo com a fase, e foram determinantes para observação desempenho do ASTBR - M II.

Para as fases II, III, IVa e Va observa-se que a concentração de ácidos efluente estava maior que o afluente, ou seja, estava ocorrendo acúmulo de ácido no sistema. Esse comportamento não é esperado em sistemas metanogênicos, uma vez que é desejada a conversão completa dos ácidos gerados na acidogênese em $\mathrm{CH}_{4} \mathrm{e} \mathrm{CO}_{2}$. A partir da fase IVb observou-se que a concentração dos ácidos presentes no afluente aumentou de acordo com a COV, enquanto que os ácidos no efluente mantiveram-se estáveis. A Figura 5.11C apresenta a variação da relação alcalinidade intermediária e parcial (AI/Ap), que corrobora com a instabilidade do sistema até o $180^{\circ}$ dia. Até a Fase Va (COV de $4,8 \mathrm{~g} \mathrm{~L}^{-1} \mathrm{~d}^{-1}$ ) a 
relação AI/Ap estava acima de 0,25 , variando de 0,25 a 0,98 , e valores elevados dessa relação demonstra que a alcalinidade do sistema se deve a presença de ácidos. A partir da Fase $\mathrm{IVb}\left(\mathrm{COV}\right.$ de 2,4 $\left.\mathrm{L}^{-1} \mathrm{~d}^{-1}\right)$ nota-se a estabilidade da relação AI/Ap abaixo de 0,25, variando de 0,14 a 0,30 , indicando a diminuição da concentração de ácidos no sistema e que o retorno para COV menor foi essencial para o restabelecimento da metanogênese no reator ASTBR - M II. A adição de $\mathrm{NaHCO}_{3}$ na relação de $1,00 \mathrm{~g} \mathrm{NaHCO}_{3} \mathrm{~g}^{-1}$ DQO contribuiu para o aumento da alcalinidade no sistema, uma vez que o afluente do ASTBRM II era proveniente do efluente acidificado gerado no ASTBR - A, e possuía pH de 3,80. 

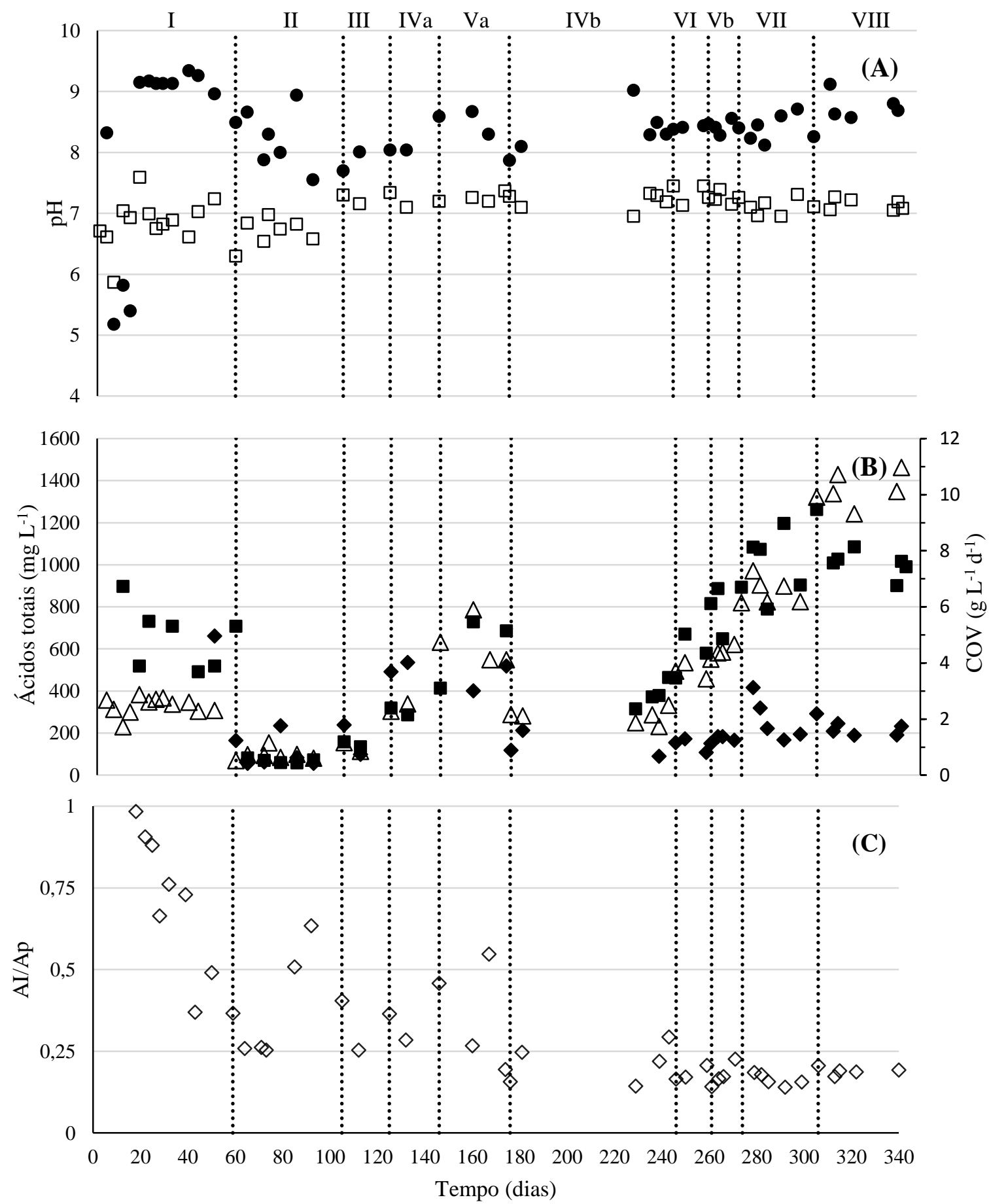

Figura 5.11 - (A) pH; (B) Variação dos ácido totais voláteis e COV; (C) Relação AI/Ap para o reator

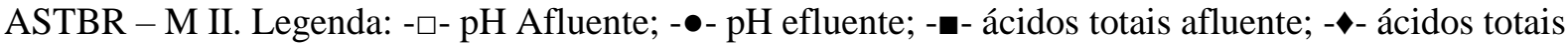
efluente; - $\Delta$ - COV; - - -relação AI/Ap 
O reator ASTBR - M II já estava inoculado e em operação (item 4.2), portanto sua operação foi iniciada neste trabalho com carga de $2,5 \mathrm{~g} \mathrm{~L}^{-1} \mathrm{~d}^{-1}$ (Fase I), e TDH de 96 horas. O reator apresentou eficiência de remoção de matéria orgânica, medida na forma de DQO, de $19,45 \pm 16,30 \%$, e próximo ao $50^{\circ}$ dia de operação atingiu valores nulos de remoção, além de ocorrer acúmulo de ácidos no sistema. Como estratégia operacional para a recuperação do sistema optou-se pela diminuição da COV para $0,6 \mathrm{~g} \mathrm{~L}^{-1} \mathrm{~d}^{-1}$ e TDH de 40 horas (Fase II). Como apresentado na Figura 5.12, o incremento gradual de carga da Fase II $\left(0,6 \mathrm{~g} \mathrm{~L}^{-1} \mathrm{~d}^{-1}\right)$ até a Fase Va $\left(4,8 \mathrm{~g} \mathrm{~L}^{-1} \mathrm{~d}^{-1}\right)$ acarretou em aumento da remoção DQO, sendo a média para as Fases II a Va de 62,30 $\pm 18,60 \%$. Nas Fases IVb, VI, Vb, VII e VIII (COV de 2,4; 3,6; 4,8; 6,00 e 10,00, respectivamente) a eficiência de remoção de DQOt e DQOs manteve maior estabilidade quando comparada às Fase I a Va. A média no período foi de $84,30 \pm 3,50 \%$ para DQOt e $90,30 \pm 2,40 \%$ para DQOs.

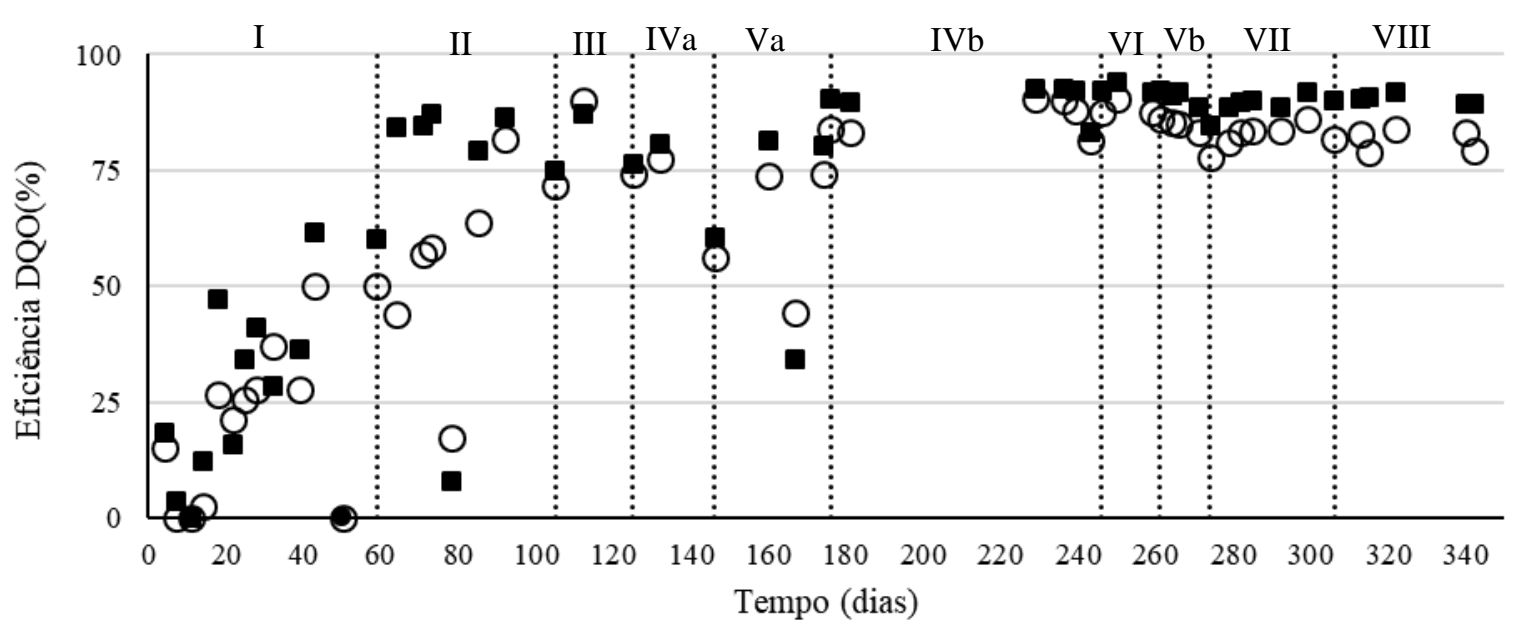

Figura 5.12 - Variação temporal da eficiência de remoção de matéria orgânica do reator ASTBR - M II. Legenda: - - remoção DQOt; -ロ- Remoção DQOs

Em um reator de duas fases (acidogênico/metanogênico) LEE et al. (2015) avaliaram a degradação do melaço de cana-de-açúcar e verificaram queda no pH de 7,0 para 5,1, quando o TDH variou de 84 horas para 56 horas. Tal variação gerou diminuição na eficiência de remoção de matéria orgânica de 77,6 para $47,1 \%$.

Destaca-se que, apesar da instabilidade do reator ASTBR - M II nas fases iniciais, houve recuperação e estabilidade do sistema, o qual apresentou eficiências de DQO e CHt próximas de reatores metanogênicos de segunda fase com diferentes substratos. 


\subsubsection{Produção de metano em ASTBR - M II}

A composição do biogás (Figura 5.13) apresentou valor médio de metano $\left(\mathrm{CH}_{4}\right)$ de $56 \pm 15 \%$, para o gás carbônico $\left(\mathrm{CO}_{2}\right)$ o valor encontrado foi de $44 \pm 15 \%$, enquanto que os gases nitrogênio $\left(\mathrm{N}_{2}\right)$ e hidrogênio $\left(\mathrm{H}_{2}\right)$ não apresentaram valores significativos. É possível observar o aumento gradual da proporção de $\mathrm{CH}_{4}$ até o $60^{\circ}$ dia, sendo $21 \%$ o menor valor obtido de $\mathrm{CH}_{4}$ no biogás para essa fase. A partir da Fase II até a Fase Va $\left(60^{\circ}\right.$ até $176^{\circ}$ dia de operação) ocorreu maior variação na proporção de $\mathrm{CH}_{4}$ e $\mathrm{CO}_{2}$, média de 65 $\pm 10 \%$ e $33 \pm 12 \%$, respectivamente. Da Fase IVb até VIII (a partir do $180^{\circ}$ dia de operação) houve maior estabilidade na proporção de biogás $60 \pm 6 \%$ de $\mathrm{CH}_{4}$ e $40 \pm 6 \%$ de $\mathrm{CO}_{2}$.

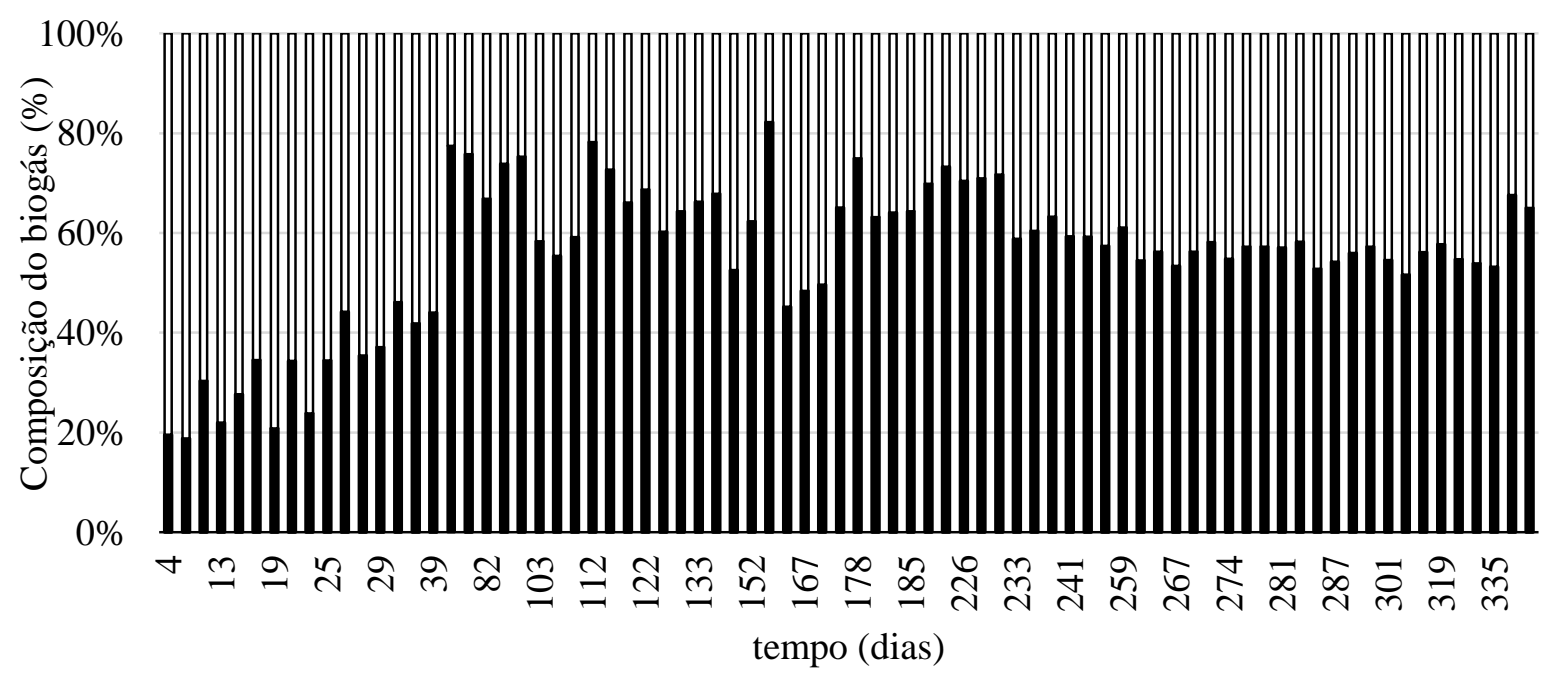

Figura 5.13 - Composição do biogás no reator ASTBR - M II. Legenda: -n- CH4 (\%); -ロ- CO2(\%)

A vazão de biogás (VBG) - Figura 5.14A, e a produção volumétrica de $\mathrm{CH}_{4}$ (PVM), foram baixas durante 176 dias de operação e não apresentava resposta ao aumento de COV, contribuindo para estratégia de reinício de partida do reator com redução da COV, conforme citado anteriormente. A VBG e PVM até a Fase Va ( $176^{\circ}$ dia) de operação foi de $22 \pm 26 \mathrm{mLCH}_{4} \mathrm{~h}^{-1}$ e $5 \pm 5 \mathrm{mLCH}_{4} \mathrm{~L}^{-1} \mathrm{~h}^{-1}$, respectivamente. Da Fase IVb até VIII, a VBG foi de $229 \pm 136 \mathrm{mLCH}_{4} \mathrm{~h}^{-1}$ e a PVM de $78 \pm 47 \mathrm{mLCH}_{4} \mathrm{~L}^{-1} \mathrm{~h}^{-1}$, associado à eficiência e estabilidade do reator.

O rendimento de metano (MY) apresentou variação durante o período de operação (Figura 5.14B), isso se deve a instabilidade do sistema, bem como problemas na medida do 
biogás, em função do gasômetro utilizado. Com o retorno da COV de 2,4 $\mathrm{g} \mathrm{L}^{-1} \mathrm{~d}^{-1}$ (Fase IVb) o rendimento médio foi de $345 \pm 110 \mathrm{mLCH}_{4} \mathrm{~g}^{-1} \mathrm{DQO}$ nas condições normais de temperatura e pressão (CNTP). O rendimento esperado nessas condições era de 350 $\mathrm{mLCH}_{4} \mathrm{~g}^{-1} \mathrm{DQO}$.

$\mathrm{Na}$ fase $\mathrm{IVb}, 182^{\circ}$ ao $235^{\circ}$ dia de operação, houve interrupção da alimentação do reator metanogênico, sendo que após esse período, observou-se valores de MY acima do esperado. Uma hipótese para esse evento é que tenha ocorrido endogenia no sistema. Em condições termofílicas a taxa de decaimento celular é maior do que sistemas mesofílicos (AMANI et al., 2015), acarretando aumento da matéria orgânica convertida a metano. A concentração de sólidos suspenso totais (SST) no efluente do reator durante as Fases I a

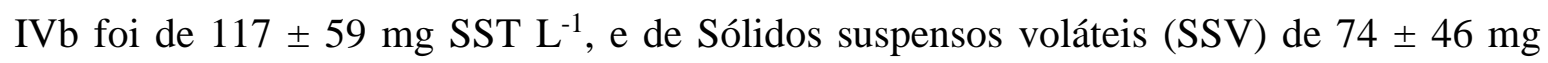
SSV L ${ }^{-1}$. Para as Fases VI a VIII a média de SST e SSV foi de $417 \pm 94 \mathrm{mg} \mathrm{SSV} \mathrm{L}^{-1}$ e 324 $\pm 88 \mathrm{mg} \mathrm{SSV} \mathrm{L}^{-1}$.

KONGJAN et al. (2013) estudaram reatores de duas fases utilizando melaço de cana-de-açúcar em condições termofílicas e encontraram valores de PVM até $141 \mathrm{mLCH}_{4}$ $\mathrm{L}^{-1} \mathrm{~h}^{-1}$ a partir de COV que variaram de 6,4 até $16,9 \mathrm{gSV} \mathrm{L}^{-1}$ dia $^{-1}$. A proporção de $\mathrm{CH}_{4} \mathrm{e}$ $\mathrm{CO}_{2}$ no biogás foi de $67 \%$ e $37 \%$. VILELA (2017) em um sistema combinado, a $55^{\circ} \mathrm{C}$ e melaço de cana-de-açúcar como substrato, submetido a COV de $60 \mathrm{~g}$ DQO L ${ }^{-1}$ dia $^{-1}$ apresentou PVM de até $110 \mathrm{mLCH}_{4} \mathrm{~L}^{-1} \mathrm{~h}^{-1}$ e composição média do biogás de 49,95\% para $\mathrm{CH}_{4}$ e $49,90 \%$ para $\mathrm{CO}_{2}$. 

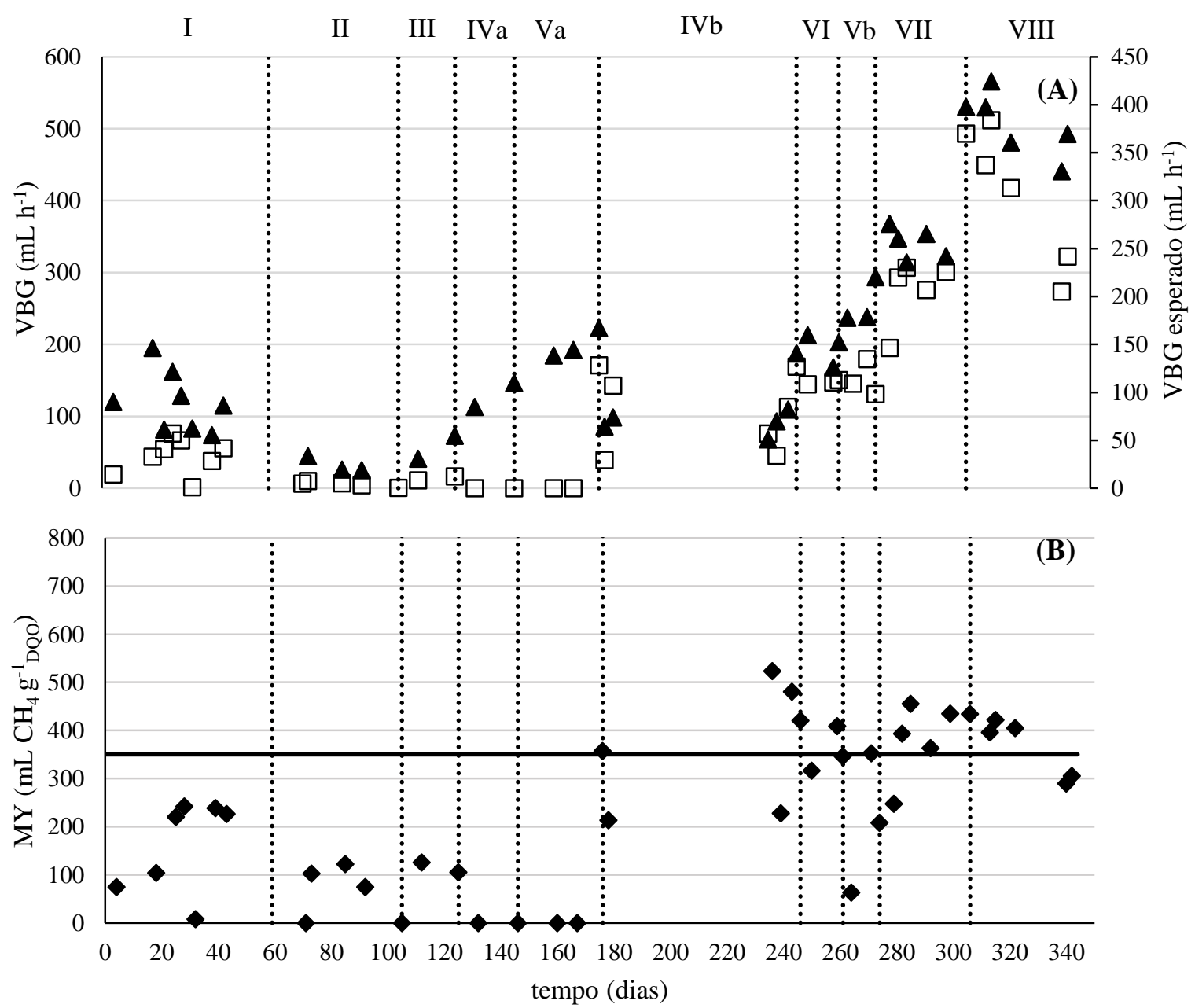

Figura 5.14 - (A) Vazão do biogás medido e esperado; (B) Rendimento de metano no reator ASTBR M II. Legenda: - -- VBG medido;- $\boldsymbol{\Delta}$ - VBG esperado

A Tabela 5.1 apresenta um resumo das médias dos valores de DQO, carboidratos, sólidos suspensos voláteis (SSV efluente), COV, e biogás obtidas para o reator metanogênico nas diferentes fases de operação. 
Tabela 5.1 - Média dos parâmetros de monitoramento do reator metanogênico ASTBR - M II para cada fase

\begin{tabular}{|c|c|c|c|c|c|c|c|c|c|c|c|}
\hline Parâmetro & Unidade & Fase I & Fase II & Fase III & Fase IVa & Fase Va & Fase IVb & Fase VI & Fase Vb & Fase VII & Fase VIII \\
\hline $\mathrm{pH}$ afluente & & 6,85 & 6,70 & 7,20 & 7,20 & 7,30 & 7,20 & 7,30 & 7,30 & 7,10 & 7,10 \\
\hline pH efluente & & 8,20 & 8,30 & 7,90 & 8,00 & 8,50 & 8,35 & 8,40 & 8,40 & 8,40 & 8,70 \\
\hline $\begin{array}{l}\text { Ácidos } \\
\text { totais } \\
\text { voláteis }\end{array}$ & $\mathrm{mg} \mathrm{L}^{-1}$ & 1086,00 & 110,00 & 170,00 & 513,00 & 841,00 & 140,00 & 145,00 & 171,00 & 264,00 & 226,00 \\
\hline Ap & $\mathrm{mg} \mathrm{CaCO}_{3} \mathrm{~L}^{-1}$ & 889,00 & 85,00 & 451,00 & 932,00 & 1830,00 & 985,00 & 1500,00 & 1862,00 & 2199,00 & 2127,00 \\
\hline DQOt & $\%$ & 19,50 & 53,10 & 80,91 & 75,90 & 62,20 & 86,20 & 88,50 & 85,00 & 88,90 & 81,60 \\
\hline DQOs & $\%$ & 20,80 & 70,90 & 81,00 & 78,50 & 64,10 & 90,20 & 93,00 & 81,00 & 94,10 & 90,30 \\
\hline $\mathrm{CHt}$ & $\%$ & 92,30 & 92,00 & 97,30 & 97,10 & 93,00 & 94,70 & 94,00 & 94,10 & 94,10 & 94,50 \\
\hline SSV & $\mathrm{mg} \mathrm{L}^{-1}$ & 20,00 & 51,00 & 64,00 & 64,00 & 155,30 & 90,00 & ND & 226,00 & 407,00 & 331,00 \\
\hline
\end{tabular}




\subsubsection{Avaliação dos produtos intermediários em ASTBR - M II}

O reator ASTBR - M II foi alimentado com o efluente acidificado do reator acidogênico ASTBR - A, razão pela qual seu afluente possui elevada concentração de ácidos orgânicos (Item 5.1.2). Os principais ácidos detectados foram: ácido lático (332 mg $\left.\mathrm{L}^{-1}\right)$, ácido cítrico $\left(251 \mathrm{mg} \mathrm{L}^{-1}\right)$, ácido butírico $\left(224 \mathrm{mg} \mathrm{L}^{-1}\right)$ e ácido acético $\left(209 \mathrm{mg} \mathrm{L}^{-1}\right)$.

Como já discutido, a baixa eficiência do reator ASTBR - M II até a Fase Va estava ligada ao acúmulo de ácidos, principalmente a ácido acético, ácido butírico e ácido propiônico, conforme mostrado na Figura 5.15A. Na Fase I (TDH de 96 horas e COV 2,5 g $\mathrm{L}^{-1} \mathrm{~d}^{-1}$ ) ocorreu a maior concentração de ácidos, principalmente acético. Com a diminuição da COV para 0,6 $\mathrm{g} \mathrm{L}^{-1} \mathrm{~d}^{-1}$ e TDH de 40 horas na Fase II, houve recuperação do sistema, fato observado pela queda na concentração de ácidos no efluente. Porém, o incremento gradual de COV nas Fases III, IVa e Va gerou um novo acúmulo de ácido no reator ASTBR - M II, atingindo a concentração de $513 \mathrm{mg} \mathrm{L}^{-1}$ de ácido acético na Fase Va. A partir do retorno da $\mathrm{COV}$ de $2,4 \mathrm{~g} \mathrm{~L}^{-1}$ na Fase $\mathrm{IVb}$, o sistema conseguiu se recuperar, melhorando a eficiência de remoção de matéria orgânica e produção de metano, evidenciado pela baixa concentração de ácido acético. A variação da concentração dos ácidos no sistema de acordo com cada fase é apresentada na Tabela 5.2. 
Tabela 5.2 - Concentração de ácidos orgânicos no efluente do reator ASTBR - M II

\begin{tabular}{cccccccccccc}
\hline Ácido orgânico & I & II & III & IVa & Va & IVb & VI & Vb & VII & VIII & VIII \\
\hline & 617,00 & 65,00 & 82,00 & 130,00 & 513,00 & 30,00 & 42,00 & 45,00 & 70,00 & 92,00 & 92,00 \\
Ácido Acético & \pm & \pm & \pm & \pm & \pm & \pm & \pm & \pm & \pm & \pm & \pm \\
& 356,00 & 65,00 & 31,00 & 118,00 & 189,00 & 31,00 & 8,00 & 14,00 & 23,00 & 57,00 & 57,00 \\
\hline & 350,00 & 28,00 & 31,00 & 56,00 & 136,00 & 0,00 & 0,00 & 0,00 & 0,00 & 0,00 & 0,00 \\
Ácido Propiônico & \pm & \pm & \pm & \pm & \pm & \pm & \pm & \pm & \pm & \pm & \pm \\
& 238,00 & 24,00 & 43,00 & 31,00 & 45,00 & 0,00 & 0,00 & 0,00 & 0,00 & 0,00 & 0,00 \\
\hline & 201,00 & 11,00 & 12,00 & 0,00 & 49,00 & 0,00 & 0,00 & 0,00 & 0,00 & 0,00 & 0,00 \\
Ácido Butírico & \pm & \pm & \pm & \pm & \pm & \pm & \pm & \pm & \pm & \pm & \pm \\
& 17,00 & 15,00 & 16,40 & 0,00 & 85,00 & 0,00 & 0,00 & 0,00 & 0,00 & 0,00 & 0,00 \\
\hline
\end{tabular}


Na Figura 5.15B nota- se que a proporção de ácido acético foi predominante no sistema, com destaque para as Fases IVb até VIII. Das Fases I a Va, a média da proporção de ácido acético foi de $60 \%$, ácido propiônico $31 \%$ e ácido butírico 9\%. As análises dos ácidos demostram que a acetogênese estava ocorrendo no sistema, porém nas fases iniciais houve grande acúmulo de ácido acético, indicando que as populações metanogênicas acetoclásticas não apresentavam atividade no sistema.

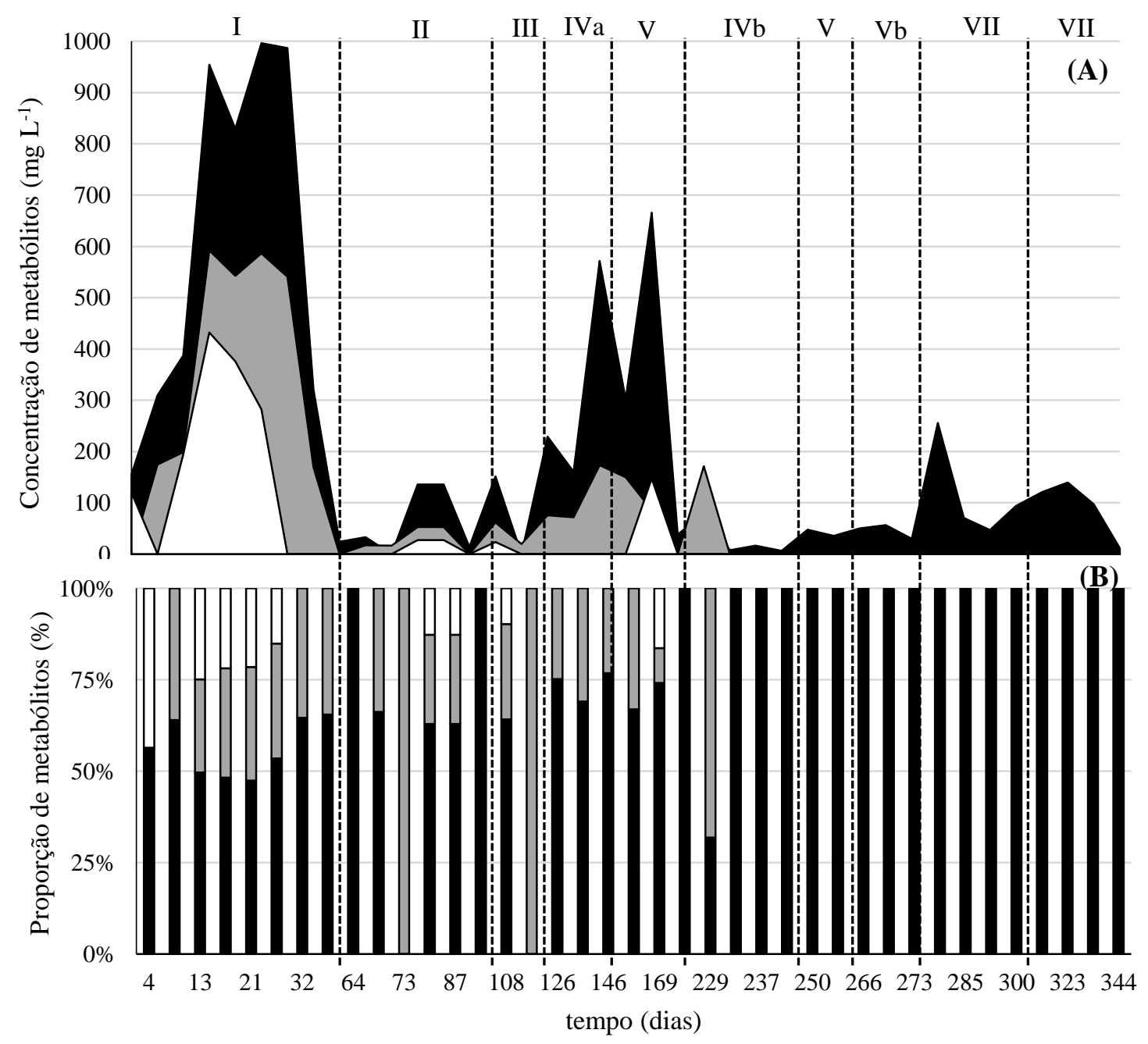

- Ácido acético $\square$ Ácido propionico $\square$ Ácido butírico

Figura 5.15 - (A) Concentração de metabólitos; (B) proporção de metabólitos no efluente do reator ASTBR - M II

Assim como para o reator ASTBR - A, foi realizado o balanço de massa para o reator metanogênico do sistema de duas fases para auxiliar na compreensão dos processos ocorridos ao longo dos 344 dias de operação, principalmente devido à elevada instabilidade do sistema até o $176^{\circ}$ dia de monitoramento. Na Figura 5.16 atenta-se para a elevada porcentagem de fração não detectável (62\%), sendo os demais 30\% compostos 
por metabólitos da fermentação e $8 \%$ dos CHs. Esse balanço de massa foi realizado com base na DQOs, uma vez que para detecção dos ácidos as amostras de efluente foram filtradas. A baixa proporção de carboidratos ao longo de toda operação do reator ASTBR M II coincide com a elevada conversão desse composto pelo sistema. Nota-se que até o $176^{\circ}$ dia de operação houve grande contribuição dos metabólitos da fermentação, seguido pela diminuição da contribuição desses compostos para a DQOs. A elevada fração não detectável pode ter contribuição de melanoidinas, a qual não é determinada pelas análises realizadas. Esse composto complexo de cor escura constitui aproximadamente $2 \%$ do melaço de cana-de-açúcar (MARTINS et al., 2011), podendo também ser encontrado em produtos alimentícios como mel e café (KAUSHIK et al., 2017). A melanoidina é formada por um reação não enzimática entre compostos aminos e carboidratos (CÄMMERER; KROH, 1995) e contribui para a carga orgânica do substrato. Porém, apenas 6-7\% dela é removida em sistemas convencionais de tratamento biológico (PEÑA et al., 2003).

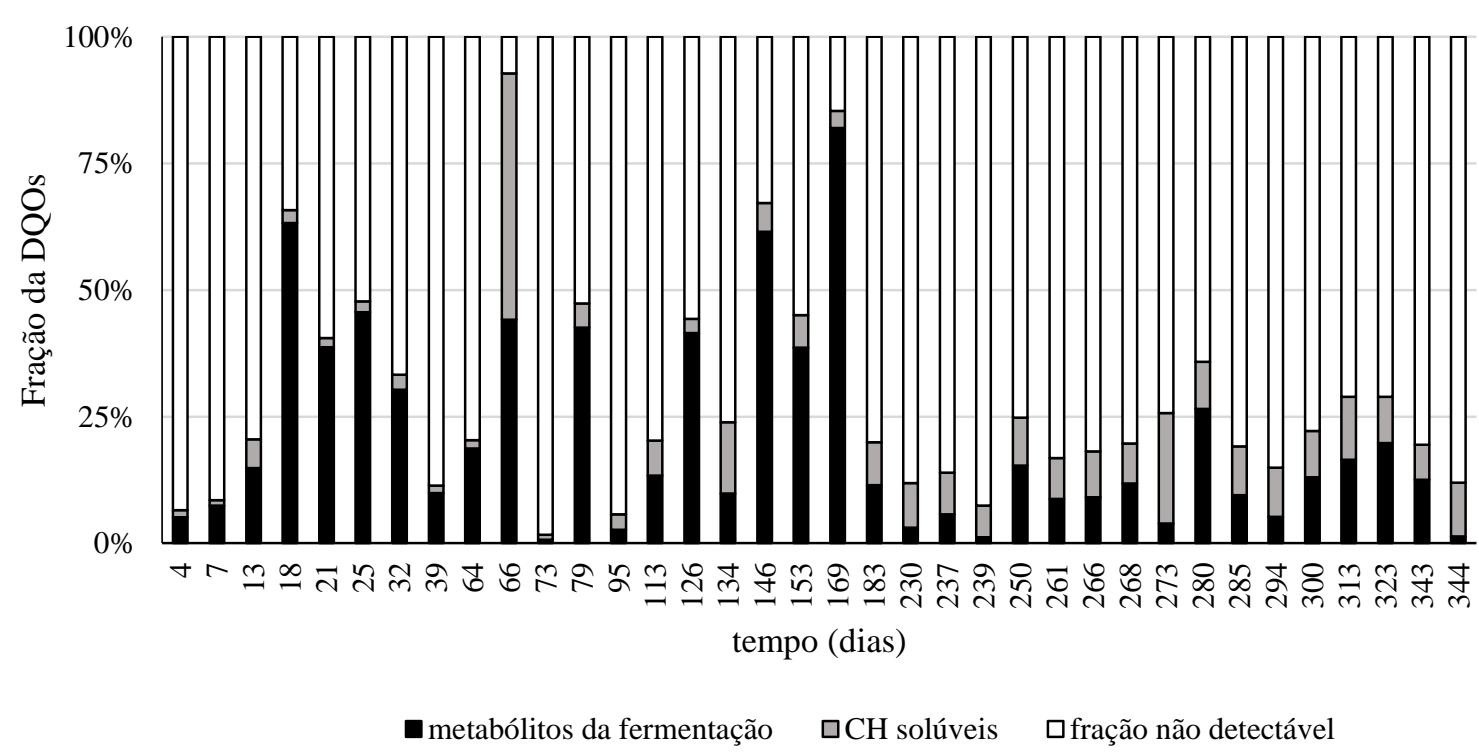

Figura 5.16 - Balanço de massa para a fase solúvel do efluente do reator ASTBR - M II 


\subsection{Desempenho do reator metanogênico - sistema de fase única (ASTBR-M I)}

No reator metanogênico de leito estruturado do sistema de fase única (ASTBR - M I) foi utilizado o mesmo material suporte e biomassa que estava no reator ASTBR - M II. Destacando que a biomassa já estava aclimatada à temperatura e ao substrato. A alimentação do reator do ASTBR - M I foi realizada com melaço diluído, e não com melaço acidificado como no sistema de duas fases (ASTBR - M II). Assim, esse sistema foi operado por 188 dias divididos nove fases. A partida (Fase I) foi realizada com COV de 2,5 $\mathrm{g} \mathrm{L}^{-1} \mathrm{~d}^{-1}$. A Fase II apresentou COV de 5,0 $\mathrm{g} \mathrm{L}^{-1} \mathrm{~d}^{-1}$ e a Fase III COV de $10,0 \mathrm{~g} \mathrm{~L}^{-1} \mathrm{~d}^{-1}$. Para essas três fases iniciais a concentração de bicarbonato de sódio $\left(\mathrm{NaHCO}_{3}\right)$ foi mantida em $1,00 \mathrm{gNaHCO}_{3} \mathrm{~g}^{-1}$ DQO. Ressaltando que para o ASTBR - M I o TDH foi de 28 horas para todas as fases (resultado da soma do TDH dos reatores do sistema combinado).

Para as Fase IV a IX a COV foi mantida em $10,0 \mathrm{~g} \mathrm{~L}^{-1} \mathrm{~d}^{-1}$ e o bicarbonato de sódio foi sendo retirado gradualmente do sistema (Fase IV - 0,75 $\mathrm{gNaHCO}_{3} \mathrm{~g}^{-1} \mathrm{DQO}$, Fase V 0,50 $\mathrm{gNaHCO}_{3} \mathrm{~g}^{-1} \mathrm{DQO}$ e Fase - VI 0,25 $\left.\mathrm{gNaHCO}_{3} \mathrm{~g}^{-1} \mathrm{DQO}\right)$. Na fase VII, em que não houve adição de alcalinizante, o sistema entrou em colapso, uma vez que o melaço é rico em carboidratos facilmente degradáveis e não possui alcalinidade, causando a acidificação do sistema, ou seja, a produção dos ácidos foi menor do que o consumo. As arqueias metanogênicas não suportaram o stress gerado no sistema que acabou por acidificar. Como estratégia para recuperação da metanogênese no ASTBR - M I, na Fase VII foi adicionado $\mathrm{NaHCO}_{3}$ na concentração de $0,25 \mathrm{gNaHCO}_{3} \mathrm{~g}^{-1} \mathrm{DQO}$, porém a dosagem foi insuficiente para neutralizar os ácidos do sistema para sua recuperação em 10 dias de operação. Optouse pela adição de $1,00 \mathrm{gNaHCO}_{3} \mathrm{~g}^{-1} \mathrm{DQO}$ (Fase IX).

A discussão do reator ASTBR - M I terá três principais estágios: $1^{\circ}$ Aumento da COV e manutenção do $\mathrm{NaHCO}_{3}$ (Fase I a III); $2^{\circ}$ Manutenção da $\mathrm{COV}$ e diminuição gradual da concentração de $\mathrm{NaHCO}_{3}$ (Fase III a VII); $3^{\circ}$ Tentativas para recuperação da metanogênese no sistema pela neutralização dos ácidos por adição de $\mathrm{NaHCO}_{3}$ (Fase VIII e IX).

Os pH afluente e efluente (Figura 5.17A) até a Fase VI mantiveram-se constantes, com média de 7,80 $\pm 0,13$ e 8,60 $\pm 0,22$, respectivamente. Na fase VII, o pH afluente foi de $6,00 \pm 0,07$ e o efluente de 4,42 $\pm 0,40$. Na fase VIII o $\mathrm{pH}$ afluente subiu para 7,70 $\pm 0,10$, 
similar a médias das Fase I a VI, mas o pH efluente continuou ácido $(4,60 \pm 0,40)$. Na fase IX, quando retornou a máxima concentração de bicarbonato de sódio, o pH afluente foi de $7,91 \pm 0,06$ e o efluente de 8,45 $\pm 0,20$, indicando geração de alcalinidade no sistema, associado à recuperação da metanogênese acetoclástica. A concentração média de ácidos voláteis totais por titulação para o afluente para todas as fases foi de $323 \pm 129 \mathrm{mg} \mathrm{L}^{-1}$, enquanto que para o efluente sofreu variação. No efluente das Fases I a VI a concentração foi de $171 \pm 88 \mathrm{mg} \mathrm{L}^{-1}$. Para a Fase VII houve um grande aumento, para $2719 \pm 158 \mathrm{mg} \mathrm{L}^{-1}$, na Fase VIII e IX a concentração de ácidos foi de $2732 \pm 242$ e $3694 \pm$ $824 \mathrm{mg} \mathrm{L}^{-1}$, respectivamente. Diante dessas concentrações e da Figura 5.17 B é possível notar que até a Fase VI o sistema encontrava-se estável e eficiente, pois não ocorreu acúmulo de ácidos. Porém, sem a adição de álcali e com a desestabilização das populações microbiológicas, não houve a neutralização desses ácidos favorecendo assim, as populações de bactérias acidogênicas e prejudicando as metanogênicas. A relação entre alcalinidade intermediaria e parcial (Figura 5.17C) foi estável para as Fases I a VI $(0,21 \pm$ 0,05). Nas fases VII e VIII essa relação não foi possível de ser medida uma vez que o efluente do sistema não possuía alcalinidade nem a bicarbonato, nem a ácido devido ao $\mathrm{pH}$ menor que 4,30. E na Fase IX a relação AI/Ap foi de 1,11 $\pm 0,14$, evidenciando o desequilíbrio no sistema pelo acúmulo de ácidos. 

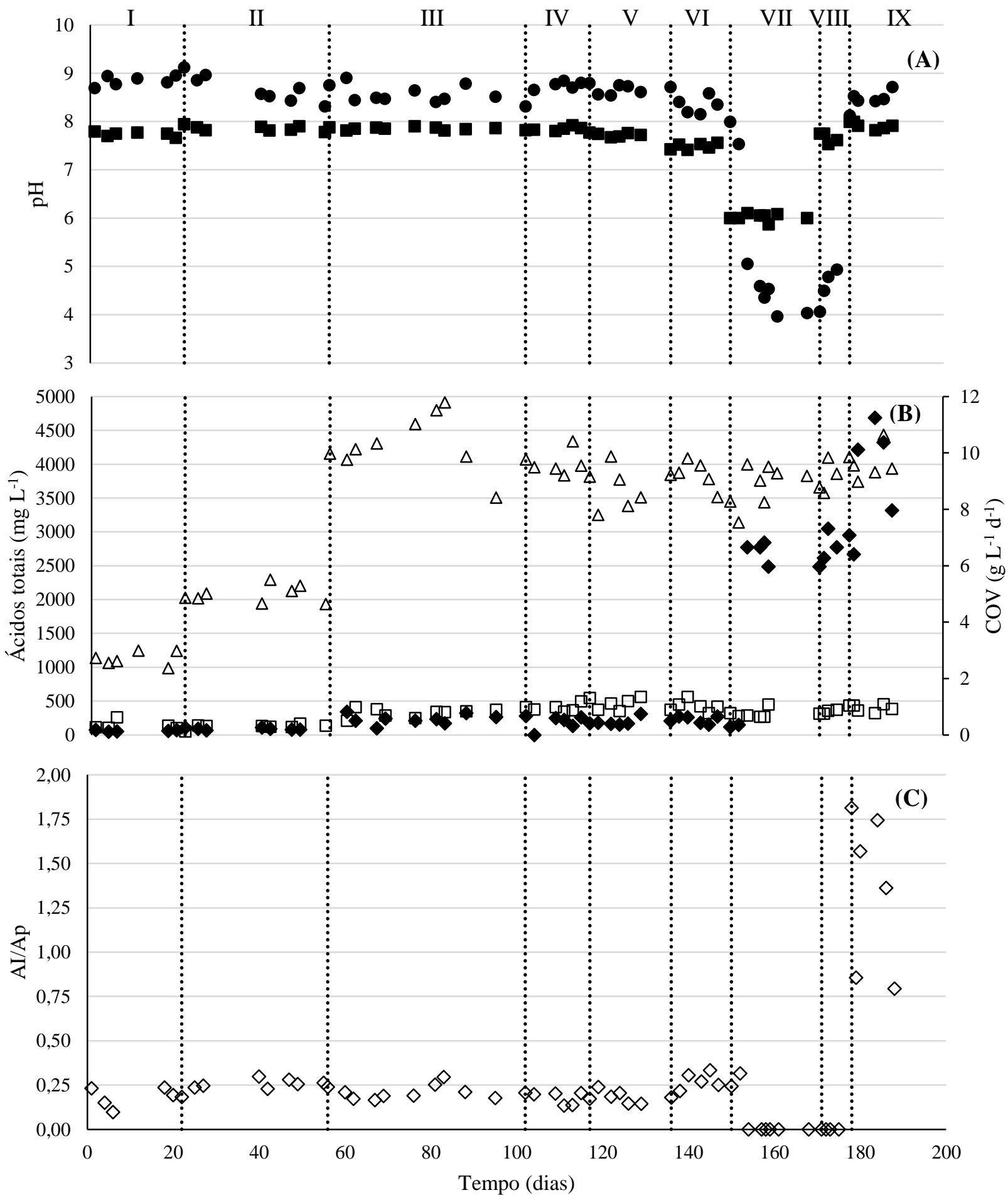

Figura 5.17 - (A) pH; (B) Variação dos ácido totais voláteis e COV; (C) Relação AI/Ap para o reator

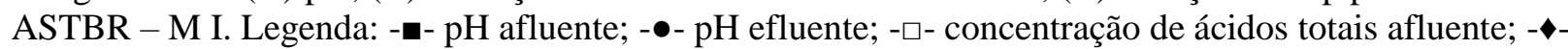
concentração de ácido totais efluente; - $\Delta-\mathrm{COV} ;-\diamond-\mathrm{AI} / \mathrm{Ap}$ 
O desequilíbrio gerado no sistema pela falta de alcalinidade acarretou em uma elevada queda na eficiência de remoção de matéria orgânica medida na forma de DQO. Até a Fase VI a eficiência para DQOt e DQOs foi de $85 \pm 3 \%$ e $93 \pm 2 \%$, respectivamente. E para as fases VII a IX a eficiência da DQOt foi de $17 \pm 7 \%$ e DQOs de $23 \pm 7 \%$. Na Figura 5.18 é possível visualizar a variação desse parâmetro ao longo da operação. Apesar das variações das concentrações de ácidos, relação AI/Ap e remoção de DQO, os carboidratos não foram afetados pelo desequilíbrio do sistema, com média para todas as fases de $96,80 \pm 2,45 \%$. Esse desempenho para a conversão de CHt manteve-se durante toda a operação do sistema, pois quando houve acúmulo de ácidos, as populações acidogênicas e acetogênicas existentes no reator não foram afetadas, porém as arqueias metanogênicas sofreram perturbação e consequentemente isso desequilibrou a relação sintrófica da digestão anaeróbia, favorecendo o crescimento das acidogênicas, e consequentemente a manutenção da conversão de $\mathrm{CH}$ que geraram o acúmulo de ácidos.

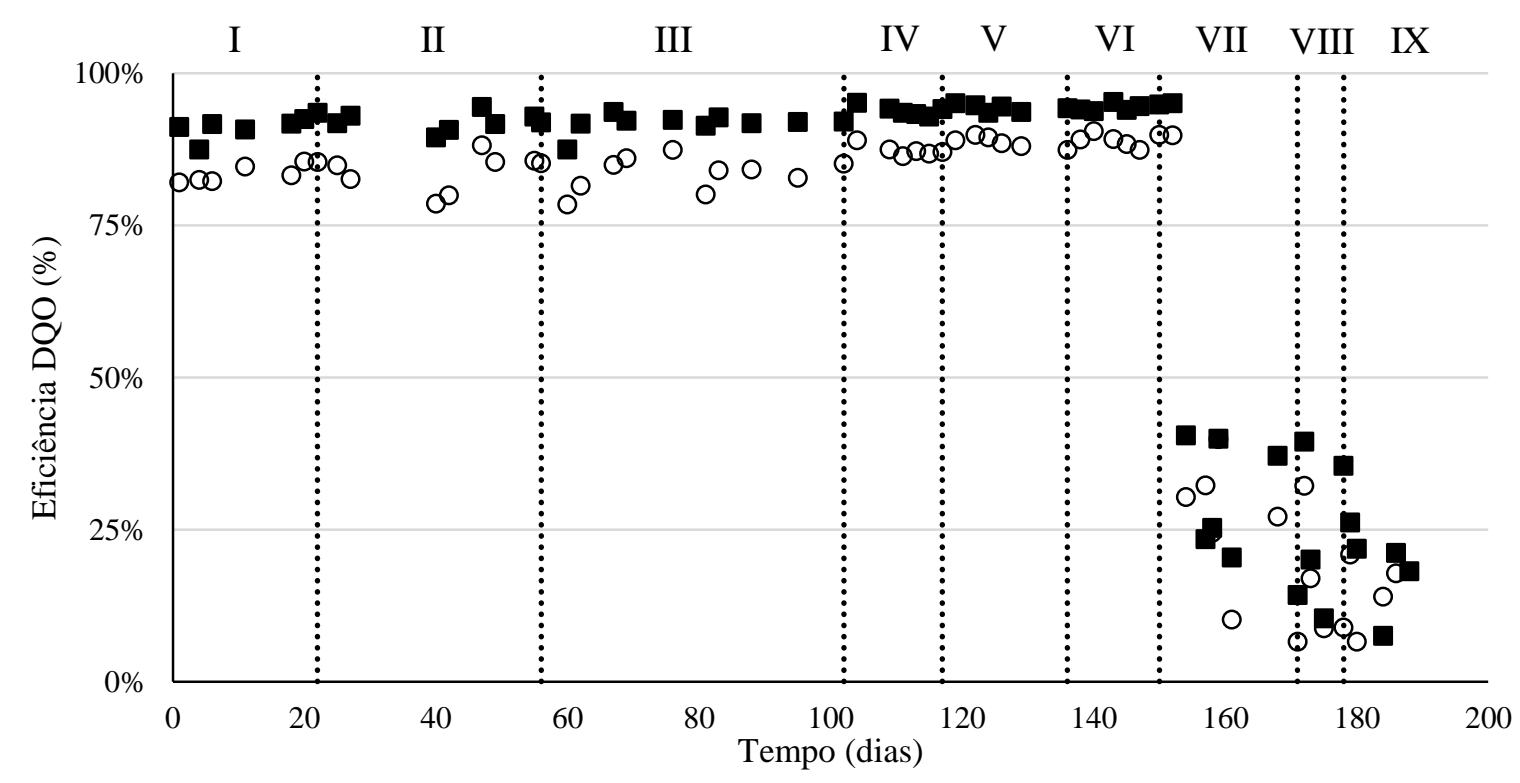

Figura 5.18 - Eficiência de remoção de matéria orgânica no reator ASTBR - M I. Legenda: -o Remoção de DQOt (\%); -m- Remoção de DQOs (\%)

\subsubsection{Produção de metano em ASTBR - M I}

A Figura 5.19 apresenta a variação da composição do biogás ao longo da operação do reator ASTBR - M I. Para as Fases I a VI a composição do biogás foi de $45 \pm 11 \%$ para o metano $\left(\mathrm{CH}_{4}\right)$ e $53 \pm 12 \%$ para o gás carbônico $\left(\mathrm{CO}_{2}\right)$. Para essas fases não foram observados os gases nitrogênio $\left(\mathrm{N}_{2}\right)$ e hidrogênio $\left(\mathrm{H}_{2}\right)$. Contudo, com a diminuição da 
concentração de $\mathrm{NaHCO}_{3}$ e o consequente acúmulo de ácidos, a composição do biogás começou a mudar gradualmente. A proporção de $\mathrm{CH}_{4}$ no biogás foi diminuindo, e o $\mathrm{H}_{2}$ foi detectado na composição do biogás até o momento em que o sistema acidificou por completo e nenhuma proporção de $\mathrm{CH}_{4}$ foi encontrada. A máxima proporção de $\mathrm{H}_{2}$ encontrada foi de $57 \%$ na Fase VII. Quando foi reiniciada a adição de $\mathrm{NaHCO}_{3}$ no sistema (Fase VIII), a proporção de $\mathrm{H}_{2}$ decaiu gradualmente, sendo que no final da Fase IX o $\mathrm{H}_{2}$ não foi mais observado no biogás do reator ASTBR - M I e a produção de $\mathrm{CH}_{4}$ reiniciada.

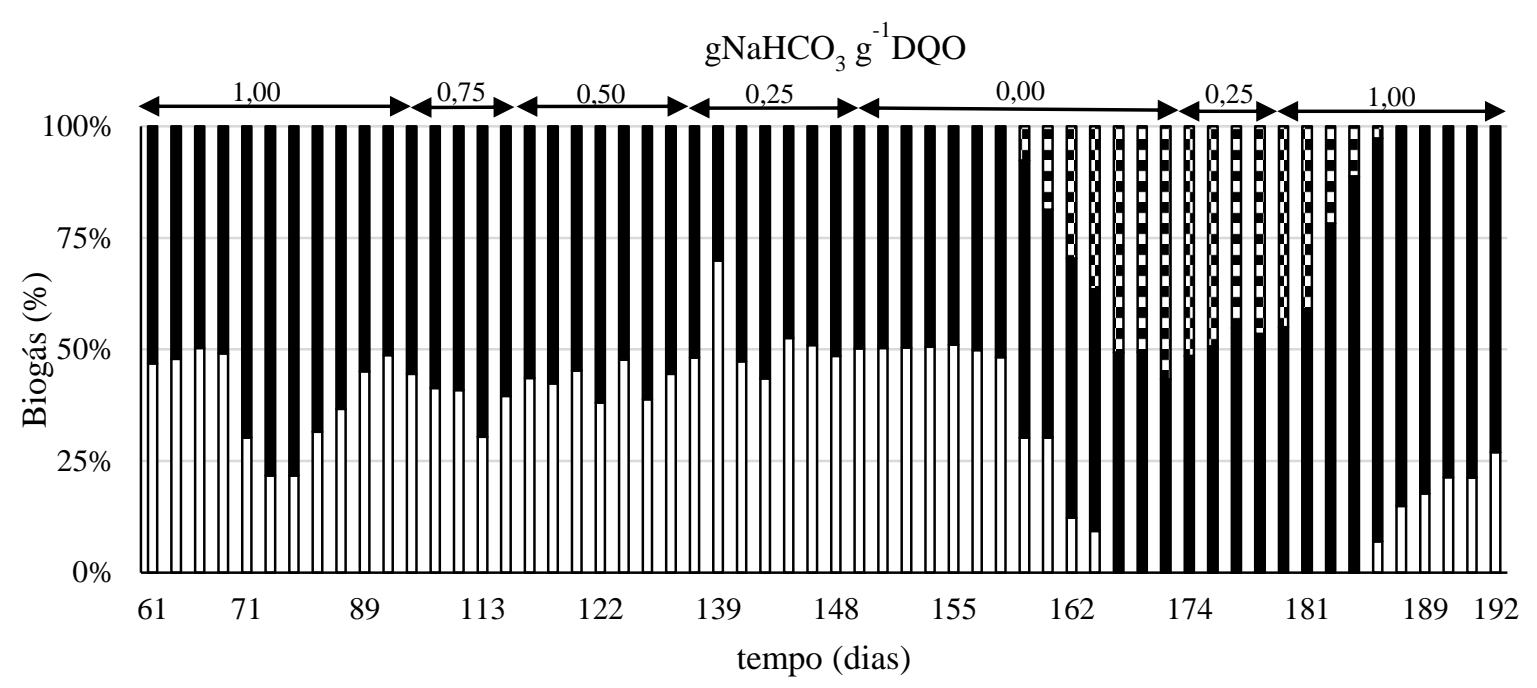

Figura 5.19 Composição do biogás no reator ASTBR - M I. Legenda:- $\Xi-\mathrm{H}_{2}(\%)$; - $-\mathrm{CH}_{4}(\%)$; $-\mathbf{- m} \mathrm{CO}_{2}(\%)$

Ressalta-se que a ausência do alcalinizante não está relacionada a desestabilização do processo, entretanto o $\mathrm{NaHCO}_{3}$ tem como função a neutralização dos ácidos e a consequente manutenção do $\mathrm{pH}$, garantindo que o sistema não acidifique. Assim, durante sete dias $\left(150^{\circ}\right.$ ao $157^{\circ}$ dia de operação) o sistema foi capaz de manter a produção de $\mathrm{CH}_{4}$ provavelmente devido a residual de alcalinidade.

A vazão do biogás (VBG) medida e esperada está representada na Figura 5.20A. É possível observar o aumento da VBG com o aumento da COV nas Fases I, II e III. Para a Fase I a VBG foi de $98 \pm 9 \mathrm{~mL} \mathrm{~h}^{-1}$ na CNTP, para a Fase II de $227 \pm 36 \mathrm{~mL} \mathrm{~h}^{-1}$ e para a Fase III $351 \pm 84 \mathrm{~mL} \mathrm{~h}^{-1}$. Na Fase IV foi obtida a maior média de vazão do sistema, $412 \pm$ $30 \mathrm{~mL} \mathrm{~h}^{-1}$. Para a Fase V a VBG foi de $338 \pm 45 \mathrm{~mL} \mathrm{~h}^{-1}$, Fase VI $367 \pm 22 \mathrm{~mL} \mathrm{~h}^{-1}$, Fase VII $191 \pm 54 \mathrm{~mL} \mathrm{~h}^{-1}$, Fase VIII $312 \pm 27 \mathrm{~mL} \mathrm{~h}^{-1}$ e na Fase IX $224 \pm 40 \mathrm{~mL} \mathrm{~h}^{-1}$. Destaca-se que a VBG apresentada na Fase VIII indica apenas que o sistema continuou produzindo biogás na forma de $\mathrm{H}_{2}$ e $\mathrm{CO}_{2}$, mas não $\mathrm{CH}_{4}$. Assim, a vazão de biogás sofreu pouca 
alteração com a remoção de $\mathrm{NaHCO}_{3}$ uma vez que quando o $\mathrm{CH}_{4}$ parou de ser produzido, o $\mathrm{H}_{2}$ foi detectado. $\mathrm{O}$ comportamento da produção volumétrica de metano (PVM) na CNTP também foi similar a VBG (Figura 5.20 B). Para as Fases I a III, que houve incremento de COV, ocorreu um aumento de $26 \pm 14 \mathrm{mLCH}_{4} \mathrm{~L}^{-1} \mathrm{~h}^{-1}$, para $72 \pm 11 \mathrm{mLCH}_{4}$ $\mathrm{L}^{-1} \mathrm{~h}^{-1}$ e $88 \pm 13 \mathrm{mLCH}_{4} \mathrm{~L}^{-1} \mathrm{~h}^{-1}$, respectivamente. Para as fases IV a VII a PVM média foi de $97 \pm 11 \mathrm{mLCH}_{4} \mathrm{~L}^{-1} \mathrm{~h}^{-1}$. Como na Fase VIII o sistema estava acidificado, não houve produção de metano. Na Fase IX a metanogênese voltou a se reestabelecer, assim a PVM foi de $26 \pm 16 \mathrm{mLCH}_{4} \mathrm{~L}^{-1} \mathrm{~h}^{-1}$.

O rendimento de metano (MY) obtido e esperado nas condições normais de temperatura e pressão estão representados na Figura 5.20C. Para a Fase I e II (COV de 2,5 e 5,0 $\mathrm{g} \mathrm{L}^{-1} \mathrm{~d}^{-1}$ ) o MY foi de $321 \pm 32 \mathrm{mLCH}_{4} \mathrm{~g}^{-1}$ DQO e $371 \pm 63 \mathrm{mLCH}_{4} \mathrm{~g}^{-1} \mathrm{DQO}$, mas na Fase III, quando a COV foi para $10,0 \mathrm{~g} \mathrm{~L}^{-1} \mathrm{~d}^{-1}$, o rendimento de $\mathrm{CH}_{4}$ teve um declínio para $20 \pm 64 \mathrm{mLCH}_{4} \mathrm{~g}^{-1} \mathrm{DQO}$. A partir dessa fase, o sistema continuou com MY abaixo do esperado de $350 \mathrm{mLCH}_{4} \mathrm{~g}^{-1}$ DQO. Para as Fases II a VII a média de MY foi de $254 \pm 50$ $\mathrm{mLCH}_{4} \mathrm{~g}^{-1}$ DQO. Na Fase VIII o MY foi nulo, e na Fase IX foi de $203 \pm 106 \mathrm{mLCH}_{4} \mathrm{~g}^{-}$ ${ }^{1}$ DQO.

Ressalta - se que apesar dos valores de vazão, PVM e MY serem apresentados para a Fase IX, o sistema ainda estava em recuperação, assim esses valores poderiam sofrer grande variação quando o sistema se estabilizasse. Eles estão sendo apresentados apenas para constatação da recuperação do reator metanogênico. 

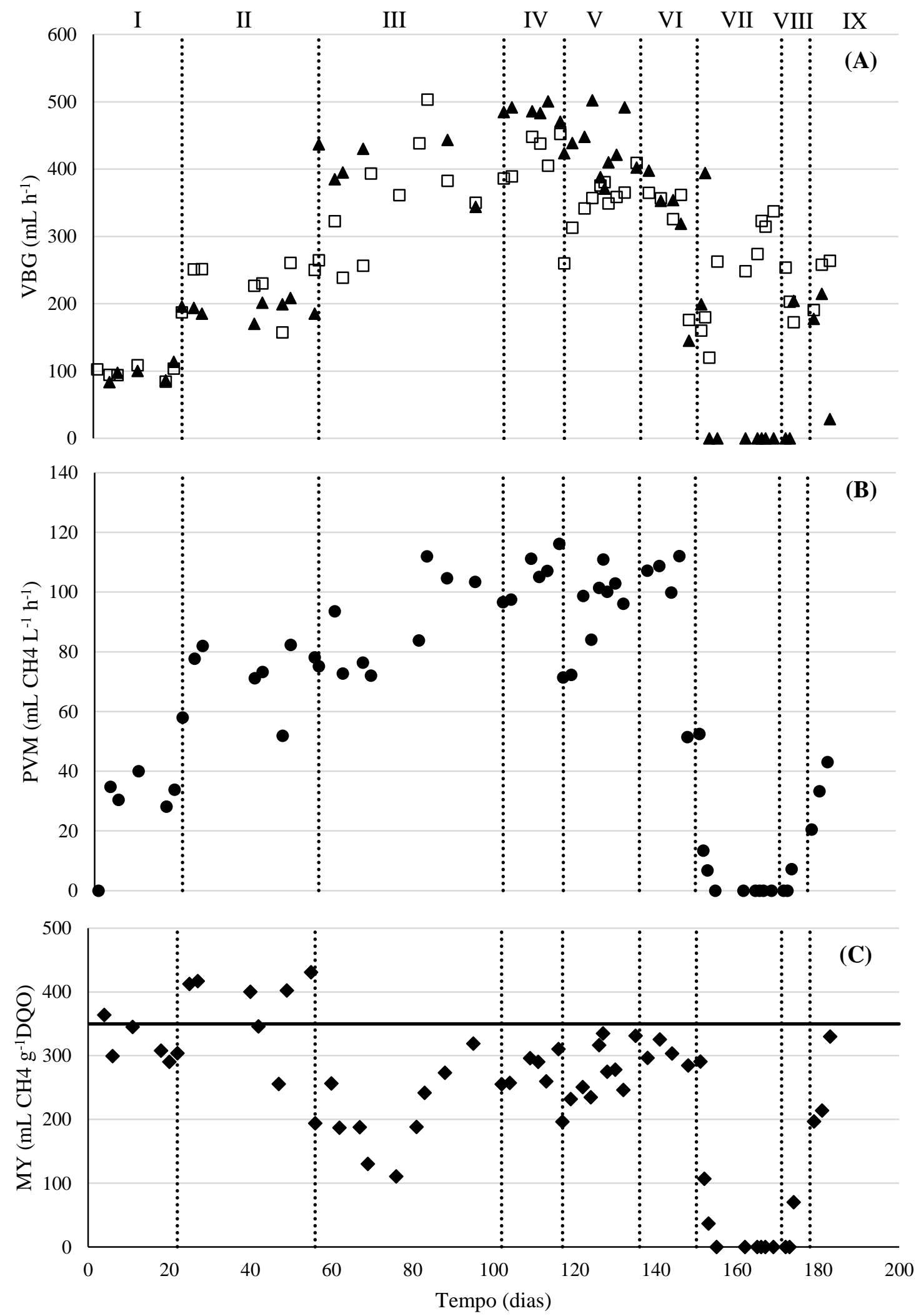

Figura 5.20 - (A) Vazão do biogás medido e esperado; (B) Produção volumétrica de metano; (C) Rendimento de metano no reator ASTBR - M I. Legenda: - $\square-$ VBG medido;- $\mathbf{A}$ - VBG esperado. 
Tabela 5.3 - Média dos parâmetros de monitoramento do reator metanogênico ASTBR - M I para cada fase

\begin{tabular}{|c|c|c|c|c|c|c|c|c|c|c|}
\hline Parâmetro & Unidade & Fase I & Fase II & Fase III & Fase IV & Fase V & Fase VI & Fase VII & Fase VIII & Fase IX \\
\hline $\mathrm{pH}$ afluente & & 7,70 & 7,90 & 7,80 & 7,80 & 7,70 & 7,50 & 6,00 & 7,70 & 7,90 \\
\hline pH efluente & & 8,80 & 8,70 & 8,60 & 8,70 & 8,60 & 8,40 & 5,25 & 4,57 & 8,45 \\
\hline Ácidos totais voláteis & $\mathrm{mg} \mathrm{L}^{-1}$ & 61,00 & 89,00 & 233,00 & 191,00 & 190,00 & 223,00 & 1857,00 & 2731,00 & 3694,00 \\
\hline Ap & $\mathrm{mg} \mathrm{CaCO}_{3} \mathrm{~L}^{-1}$ & 566,00 & 1029,00 & 1997,00 & 1812,00 & 1256,00 & 623,00 & 50 & 0,00 & 945,00 \\
\hline $\mathrm{AI}$ & $\mathrm{mg} \mathrm{CaCO}_{3} \mathrm{~L}^{-1}$ & 104,00 & 254,00 & 415,00 & 326,00 & 224,00 & 158,00 & 13,00 & 0,00 & 1181,00 \\
\hline DQOt & $\%$ & 83 & 84 & 83 & 87 & 89 & 89 & 43 & 16 & 12 \\
\hline DQOs & $\%$ & 91 & 92 & 92 & 93 & 94 & 94 & 47 & 21 & 22 \\
\hline $\mathrm{CHt}$ & $\%$ & 97 & 97 & 97 & 98 & 98 & 98 & 94 & 92 & 96 \\
\hline SSV & $\mathrm{mg} \mathrm{L}^{-1}$ & 162,00 & 330,00 & 404,00 & 335,00 & 266,00 & 237,00 & 24,00 & 264,00 & 454,00 \\
\hline PVM & $\mathrm{mLCH}_{4} \mathrm{~L}^{-1} \mathrm{~h}^{-1}$ & 26,00 & 71,00 & 88,00 & 105,00 & 89,00 & 103,00 & 39,00 & 0,00 & 26,00 \\
\hline MY & $\mathrm{mLCH}_{4} \mathrm{gDQO}^{-1}$ & 321,00 & 371,00 & 208,00 & 278,00 & 261,00 & 292,00 & 279,00 & 0,00 & 208,00 \\
\hline
\end{tabular}


5.3.2 Avaliação dos produtos intermediários e efeito do alcalinizante no reator metanogênico ASTBR - M I

A concentração dos metabólitos no efluente do reator ASTBR - M II (Figura 5.21A) foi realizada com base nos ácidos orgânicos voláteis. Para as Fases I a III, período de incremento gradual de $\mathrm{COV}$ e concentração fixa de $1,00 \mathrm{~g} \mathrm{NaHCO}_{3} \mathrm{~g}^{-1} \mathrm{DQO}$ só foi determinado o ácido acético no efluente do sistema, com concentração média de $27 \pm 19$ $\mathrm{mg} \mathrm{L}^{-1}$. Nas Fases V e VI não houve determinação de nenhum ácido orgânico, apesar de ter sido observado uma concentração de $202 \pm 74 \mathrm{mg} \mathrm{L}^{-1}$ de ácidos totais por titulação. Nas Fases VII, VIII e IX (151 a $188^{\circ}$ dia de operação) é possível observar uma variação na concentração dos metabólitos, e consequentemente na proporção (Figura 5.21B), indicando mudança na rota metabólica do sistema. Para a Fase VII não foi adicionado $\mathrm{NaHCO}_{3}$, verificando o acúmulo progressivo de ácido acético tanto pela concentração (1700 \pm 350 $\mathrm{mg} \mathrm{L}^{-1}$ ), bem como pela queda na proporção de ácido acético entre os metabólicos. Nessa fase foram observadas pequenas concentrações de ácido propiônico $\left(26 \pm 46 \mathrm{mg} \mathrm{L}^{-1}\right)$, mas elevadas concentrações de ácido isobutirico $\left(2300 \pm 732 \mathrm{mg} \mathrm{L}^{-1}\right)$. Quando a adição de $\mathrm{NaHCO}_{3}$ foi retomada no reator na concentração de $0,25 \mathrm{~g} \mathrm{NaHCO}_{3} \mathrm{~g}^{-1}$ DQO (Fase VIII) o ácido acético apresentava concentração média de $1208 \pm 68 \mathrm{mg} \mathrm{L}^{-1}$ e o ácido isobutírico $2251 \pm 0 \mathrm{mg} \mathrm{L}^{-1}$. Na Figura 5.20B é possível observar que o $\mathrm{CH}_{4}$ voltou a ser produzido em baixa proporção, contudo ainda havia acúmulo de ácidos no sistema. O ácido acético teve concentração média de $4939 \pm 296 \mathrm{mg} \mathrm{L}^{-1}$, ácido propiônico $1367 \pm 429 \mathrm{mg} \mathrm{L}^{-1}$, ácido isobutírico $1749 \pm 309 \mathrm{mg} \mathrm{L}^{-1}$ e ácido butírico $493 \pm 271 \mathrm{mg} \mathrm{L}^{-1}$. Como citado anteriormente, o período de tempo disponível para avaliar a recuperação do sistema foi insuficiente.

A proporção de metabólitos (Figura 5.21B) até o $150^{\circ}$ dia de operação foi predominantemente de ácido acético. Quando o $\mathrm{NaHCO}_{3}$ foi retirado totalmente do sistema, houve modificação na proporção dos ácidos no sistema. Ácido propiônico foi observado na proporção de $37 \%$ logo no início da fase VII, e o ácido isobutírico contribuiu com $68 \%$ na porporção para essa mesma fase. Na fase IX, houve maior variação na proporção dos ácidos: ácido acético $61 \%$, ácido propiônico $23 \%$, ácido isobutírico $7 \%$ e ácido butírico $10 \%$. 
Para as Fases I a III, com concentrações crescentes de COV e adição de 1,00 gNaHCO3 $\mathrm{g}^{-1} \mathrm{DQO}$, é possível observar o sintrofismo entre bactérias acidogênicas, bactérias acetogênicas e arqueias metanogênicas. A concentração de ácido acético no efluente foi de aproximadamente $27 \mathrm{mg} \mathrm{L}^{-1}$ e não houve produção de $\mathrm{H}_{2}$. Essas observações corroboram a metanogênese completa realizada tanto pelas arqueias acetoclásticas, quanto pelas arqueias hidrogenotróficas.
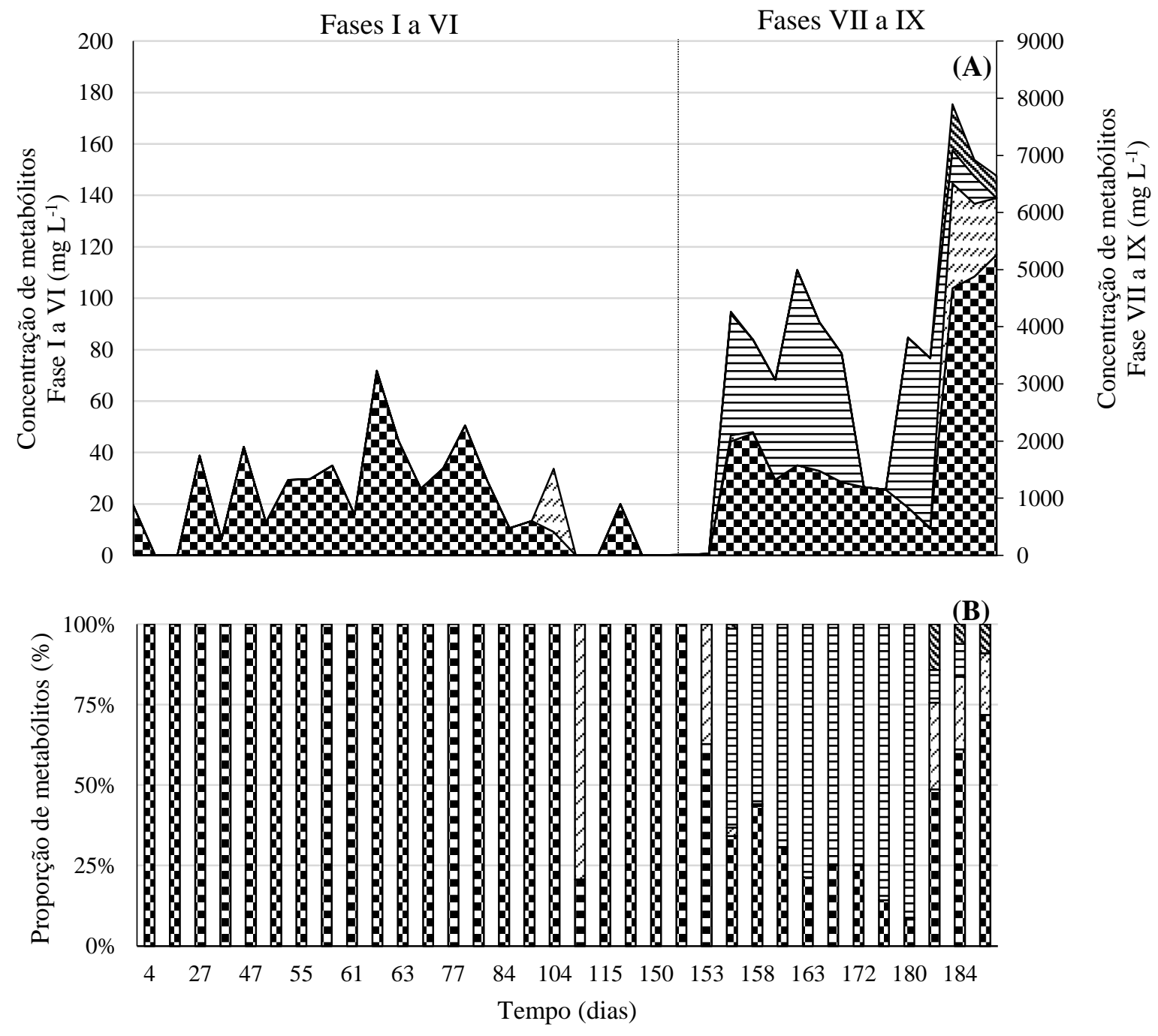

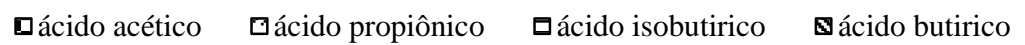

Figura 5.21 - (A) Concentração de metabólitos; (B) proporção de metabólitos no efluente do reator ASTBR - M I 
Na Tabela 5.4 são apresentadas as concentrações médias dos ácidos acético, propiônico, isobutírico e butírico para as nove fases de operação do reator ASTBR - M I.

Tabela 5.4 - Concentração de ácidos orgânicos no efluente do reator ASTBR - M I

\begin{tabular}{|c|c|c|c|c|c|c|c|c|c|}
\hline $\begin{array}{c}\text { Ácido } \\
\text { orgânico }\end{array}$ & I & II & III & IV & $\mathbf{V}$ & VI & VII & VIII & IX \\
\hline \multirow{3}{*}{$\begin{array}{l}\text { Ácido } \\
\text { Acético }\end{array}$} & 20,0 & 30,0 & 38,0 & 14,0 & 0,0 & 0,0 & 1700,0 & 1208,0 & 4939,0 \\
\hline & \pm & \pm & \pm & \pm & \pm & \pm & \pm & \pm & \pm \\
\hline & 0,0 & 11,0 & 17,0 & 5,0 & 0,0 & 0,0 & 350,0 & 67,0 & 296,0 \\
\hline \multirow{3}{*}{$\begin{array}{c}\text { Ácido } \\
\text { Propiônico }\end{array}$} & 0,0 & 0,0 & 0,0 & 0,0 & 0,0 & 0,0 & 26,0 & 0,0 & 1367,0 \\
\hline & \pm & \pm & \pm & \pm & \pm & \pm & \pm & \pm & \pm \\
\hline & 0,0 & 0,0 & 0,0 & 0,0 & 0,0 & 0,0 & 46,0 & 0,0 & 429,0 \\
\hline \multirow{3}{*}{$\begin{array}{c}\text { Ácido } \\
\text { isobutírico }\end{array}$} & 0,0 & 0,0 & 0,0 & 0,0 & 0,0 & 0,0 & 2300,0 & 2251,0 & 1749,0 \\
\hline & \pm & \pm & \pm & \pm & \pm & \pm & \pm & \pm & \pm \\
\hline & 0,0 & 0,0 & 0,0 & 0,0 & 0,0 & 0,0 & 733,0 & 0,0 & 309,0 \\
\hline \multirow{3}{*}{$\begin{array}{c}\text { Ácido } \\
\text { Butírico }\end{array}$} & 0,0 & 0,0 & 0,0 & 0,0 & 0,0 & 0,0 & 0,0 & 0,0 & 493,0 \\
\hline & \pm & \pm & \pm & \pm & \pm & \pm & \pm & \pm & \pm \\
\hline & 0,0 & 0,0 & 0,0 & 0,0 & 0,0 & 0,0 & 0,0 & 0,0 & 271,0 \\
\hline
\end{tabular}

A produção de $\mathrm{H}_{2}$ nas fases finais, gerou um aumento da pressão parcial desse gás no sistema fazendo com que as bactérias acetogênicas parassem de produzir acetato, e a acetogênese é essencial para manutenção da pressão parcial de $\mathrm{H}_{2}$ dentro dos limites. Todo esse processo gerou a inibição das arqueias metanogênicas hidrogenotróficas e acetoclásticas, ocasionando a falta de $\mathrm{CH}_{4}$ na composição do biogás. A produção de ácido acético, butírico, isobutírico e propiônico a partir da Fase VII indicam uma mudança e instabilidade do sistema assim como ocorreu no início da operação do reator ASTBR - M II do sistema combinado (Figura 5.15).

Na Fase IX observou-se um aumento da concentração de ácido acético e isobutirico quando comparado com as fases VII e VIII, entretanto a produção de $\mathrm{CH}_{4}$ foi retomada e houve queda da produção de $\mathrm{H}_{2}$ até sua total inibição. Portanto, com o acúmulo de ácido acético, baixa produção de $\mathrm{H}_{2}$ e aumento do $\mathrm{CH}_{4}$, pode-se inferir que houve o reestabelecimento da metanogênese via arqueias hidrogenotróficas, ou seja, esses 
microrganismos se recuperaram mais rapidamente do que as arqueias acetoclásticas. De acordo com MOSEY; MATTER (1983) as acetoclásticas produtoras de $\mathrm{CH}_{4}$ tem um crescimento lento, entre 2 e 3 dias, enquanto que as arqueias hidrogenotróficas apresentam tempo mínimo de crescimento de 6 horas. De acordo com HAO et al., $2012 \mathrm{em} \mathrm{pH}$ entre 6,0 e 6,5 com concentrações de acetato próximas a 5,9 $\mathrm{g} \mathrm{L}^{-1}$, a produção de $\mathrm{CH}_{4}$ ocorreu principalmente via arqueias metanogênicas acetoclasticas, e em condições ácidas, $\mathrm{pH}$ de 5,5, a rota preferencial para produção de metano foi via arqueias metanogênicas hidrogenotroficas. No presente reator, ASTBR - M I, o pH na fase VIII, momento em que a metanogênese estava se reestabelecendo, foi de 4,57, e a concentração de ácido acético de aproximadamente 5,0 $\mathrm{g} \mathrm{L}^{-1}$ corroborando o acelerado crescimento das hidrogenotróficas em detrimento das acetoclásticas. Além do mais, o aumento na concentração de bicarbonato em sistemas termofílicos foi avaliada como favorável para a produção de $\mathrm{CH}_{4}$ via hidrogenotróficas, em contrapartida, concentrações de bicarbonato próximas a 12 $\mathrm{gNaHCO}_{3} \mathrm{~L}^{-1}$ reduziram as taxas de produção de metano e a degradação de acetato (LIN et al., 2013).

O balanço de massa para o reator ASTBR - M I (Figura 5.22) foi realizado com base na fase solúvel do efluente, e para as Fases I a VI (até o $164^{\circ}$ dia de operação) a maior fração da DQOs não foi especiada, aproximadamente $85 \pm 4 \%$, sendo o CHs responsável por $12 \pm 3 \%$ da composição da DQOs, e apenas $3 \pm 4 \%$ dos metabólitos da fermentação. Para as Fases VII e IX a fração não detectável caiu para $36 \pm 39 \%$, a proporção de CHs foi de $6 \pm 6 \%$ e os metabólitos da fermentação de $35 \pm 41 \%$. Comportamento semelhante foi observado no reator ASTBR - M II, uma vez que até a Fase IVb o sistema estava instável, e 59\% da DQOS correspondeu a fração não detectável. Quando o sistema se estabilizou (Fases VI a VII) a fração não detectável aumentou para 78\%. Isso se deve a queda na produção de ácidos, diminuindo a contribuição dos metabólitos da fermentação. Assim como discutido no Item 5.2.2, a elevada fração não detectável está relacionada à presença da melanoidina. Esse composto tem alta solubilidade em pH elevado (MOHANA et al., 2007), permitindo inferir que o $\mathrm{pH}$ acima de 8,0 durante o período de estabilidade dos sistemas metanogênicos acarreta em uma maior solubilidade da melanoidina, fazendo com que ela esteja presente na fração não detectável. 


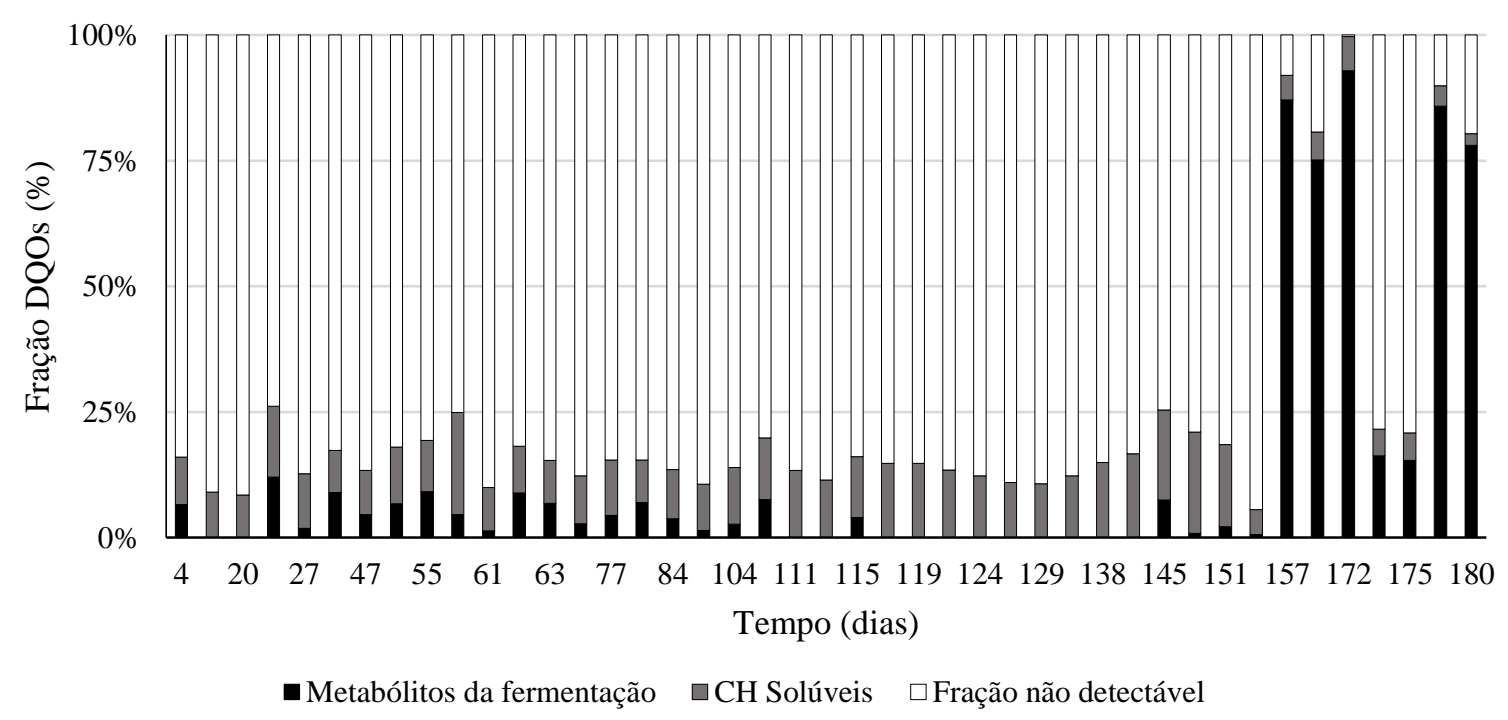

Figura 5.22 - Balanço de massa para a fase solúvel do efluente do reator ASTBR - M I

A oscilação na concentração dos metabólitos, bem como nas demais variáveis de monitoramento do reator ASTBR - M I evidenciaram que a ausência de alcalinidade diante de um substrato rico em carboidrato e facilmente biodegradado, como o melaço, afetou as comunidades microbianas e consequentemente as suas rotas metabólicas. Logo, a adição de alcalinizantes nesses sistemas deve ser melhor avaliado, uma vez que há necessidade de suprimir ou reduzir esses compostos químicos em função dos elevados custos envolvidos.

A Tabela 5.5 apresenta a variação da concentração de $\mathrm{NaHCO}_{3}$ em diferentes reatores anaeróbios operados em condições termofílicas e mesofílicas. Os valores apresentados são referentes a menor concentração obtida para manutenção do equilíbrio do sistema e não necessariamente a de melhor rendimento. DOLL; FORESTI (2010) utilizaram reator anaeróbio operado em bateladas sequencias (AnSBBR) para avaliar o efeito de bicarbonato de sódio no tratamento da vinhaça de cana-de-açúcar a $35^{\circ} \mathrm{C}$ e $55^{\circ} \mathrm{C}$. Os autores concluíram que condições mesofílicas proporcionam maior estabilidade, sendo menos dependente de alcalinizante para manutenção da metanogênse. Em sistemas mesofílicos, a menor concentração utilizada foi de $0,10 \mathrm{gNaHCO}_{3} \mathrm{~g}^{-1} \mathrm{DQO}$, enquanto que para termofílicos foi de $0,20 \mathrm{gNaHCO}_{3} \mathrm{~g}^{-1} \mathrm{DQO}$, mas com COV diferentes. Realizando a comparação com COV semelhantes, BARBOSA (2017) atingiu uma concentração de 0,30 $\mathrm{gNaHCO}_{3} \mathrm{~g}^{-1} \mathrm{DQO}$ utilizando o melaço como substrato a $35^{\circ} \mathrm{C}$, enquanto FUESS (2017) obteve uma concentração pouco menor, de $0,28 \mathrm{gNaHCO}_{3} \mathrm{~g}^{-1} \mathrm{DQO}$ em condições 
termofílicas. Para o presente trabalho, a menor concentração de $\mathrm{NaHCO}_{3}$ obtida, objetivando o equilíbrio do sistema, foi de $0,25 \mathrm{gNaHCO}_{3} \mathrm{~g}^{-1} \mathrm{DQO}$.

Como alternativa ao $\mathrm{NaHCO}_{3}$ BONCZ et al. (2012) avaliaram a utilização da uréia para evitar a acidificação dos tratamentos anaeróbios a partir da vinhaça de cana-de-açúcar. Com a adição de uréia foi possível diminuir a concentração de bicarbonato do sistema sem interferir na estabilidade do mesmo. Porém, deve-se atentar para a toxicidade da amônia presente nesse composto para sistemas anaeróbios. Os reatores metanogênicos desse estudo, ASTBR - M I e ASTBR - M II, precisaram de complementação com solução de nitrogênio e fósforo, a utilização da uréia é uma boa alternativa para futuros estudos, pois além de minimizar os custos com o $\mathrm{NaHCO}_{3}$, não seria necessária utilização de solução complementar de nutrientes. Além disso, concentrações acima de 19,2 $\mathrm{g} \mathrm{L}^{-1}$ de sódio e potássio em reatores operando com melaço acarretam em inibição da metanogênese (DE VRIEZE et al., 2016;JHA;SCHMIDT,2017). 
Tabela 5.5 - Concentrações de $\mathrm{NaHCO}_{3}$ para a digestão da vinhaça e melaço de cana-de-açúcar em sistemas anaeróbios

\begin{tabular}{|c|c|c|c|c|c|c|}
\hline & & Reator & $\operatorname{COV}\left(g^{-1} d^{-1}\right)$ & Substrato & $\mathrm{gNaHCO}_{3} \mathrm{~g}^{-1} \mathrm{DQO}$ & Referência \\
\hline \multirow{4}{*}{ 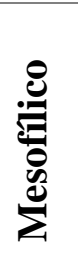 } & \multirow{4}{*}{$\begin{array}{l}0 \\
\text { in } \\
\text { co }\end{array}$} & USSB & 11,00 & Melaço de cana - de - açúcar & 0,20 & ONODERA et al. (2013) \\
\hline & & UASB & 42,00 & Melaço de cana- de - açúcar & 0,10 & KURODA et al. (2015) \\
\hline & & UASB & 33,00 & Melaço de cana - de - açúcar & 0,30 & BARBOSA (2017) \\
\hline & & AnSBBR & 36,00 & Vinhaça de cana - de - açúcar & 0,20 & DOLL; FORESTI (2010) \\
\hline \multirow{5}{*}{\multicolumn{2}{|c|}{ 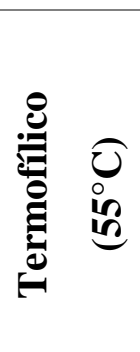 }} & AnSBBR & 5,24 & Vinhaça de cana - de - açúcar & 0,40 & DOLL; FORESTI (2010) \\
\hline & & UASB & 15,00 & Vinhaça de cana - de - açúcar & 0,36 & FERRAZ JR. et al. (2016) \\
\hline & & UASB e ASTBR & 30,00 & Vinhaça de cana - de - açúcar & 0,28 & FUESS (2017) \\
\hline & & ASTBR & 11,00 & Melaço de cana- de - açúcar & 0,20 & VILELA (2017) \\
\hline & & ASTBR & 10,00 & Melaço de cana - de - açúcar & 0,25 & Este trabalho \\
\hline
\end{tabular}




\subsection{Análise e comparação dos sistemas de duas fases (ASTBR-M II) e fase única (ASTBR- M I)}

Nessa seção foi realizada uma comparação entre fases semelhantes aplicadas nos reatores metanogênicos do sistema de duas fases (ASTBR - M II) e sistema de fase única (ASTBR - M I). As fases comparadas (Fase VIII para ASTBR - M II e Fase III para ASTBR - M I) apresentaram mesma carga orgânica e mesma concentração de alcalinizante na forma de bicarbonato de sódio.

Ressalta-se que para obtenção da eficiência de DQOt, DQOs e CHt para o reator metanogênico do sistema de duas fases (ASTBR - M II), foram utilizados os valores afluentes do reator acidogênico. A fase do sistema combinado utilizada para comparação com o sistema único encontrava-se com funcionamento adequado e o único diferencial com a fase do sistema único foi o TDH, como apresentado na Tabela 5.6.

Tabela 5.6 - Diferenças operacionais entre as fases VIII e III dos reatores metanogênicos ASTBR M II e ASTBR - M I

\begin{tabular}{ccccc}
\hline Reator & Fase de operação & $\mathbf{C O V}\left(\mathbf{g ~ L}^{-\mathbf{1}} \mathbf{d}^{\mathbf{- 1}}\right)$ & $\mathbf{T D H}(\mathbf{h})$ & $\begin{array}{c}\text { Alcalinizante } \\
\left(\mathbf{g N a H C O 3} \mathbf{~}^{-\mathbf{1}} \mathbf{D Q O}\right)\end{array}$ \\
\hline ASTBR - M II & Fase VIII & 10,00 & 24 & 1,00 \\
\hline ASTBR - M I & Fase III & 10,00 & 28 & 1,00
\end{tabular}

$\mathrm{O} \mathrm{pH}$ afluente para o reator do sistema de duas fases foi 7,15 , enquanto que para o sistema de fase única foi de 7,85. Essa diferença se deve ao tipo de alimentação, uma vez que para o sistema combinado a alimentação afluente era proveniente de um reator acidogênico, portanto, melaço acidificado. Em contrapartida a pequena diferença de pH afluente, o pH efluente foi semelhante, de 8,6. A relação AI/Ap para ASTBR - M II e MI foi de $0,20 \pm 0,02$ e $0,21 \pm 0,04$, respetivamente, ficando dentro do esperado para um bom desempenho de reatores metanogênicos.

Para os parâmetros de remoção de DQOt e DQOs, bem como para a conversão de $\mathrm{CHt}$, as médias foram de 82,0 $\pm 2,0 \%$ para DQOt, $91,0 \pm 2,0 \%$ DQOs e $94,0 \pm 0,1 \%$ de CHt para o reator ASTBR - M II e para o reator do sistema único - ASTBR - M I as médias, seguindo os mesmos parâmetros foram de 83,0 $\pm 2,0 \%, 92,0 \pm 2,0 \%$ e 98,0 \pm 0,3 \%. Os valores de remoção de DQOt, bem como suas médias são apresentados na Figura 
5.23A, enquanto que a DQOs está na Figura 5.23B e a relação AI/Ap na Figura 5.23C. Para a remoção de DQOt e relação AI/Ap nota-se que houve maior variação no reator do sistema único, enquanto que o parâmetro DQOs foi mais estável para esse sistema.
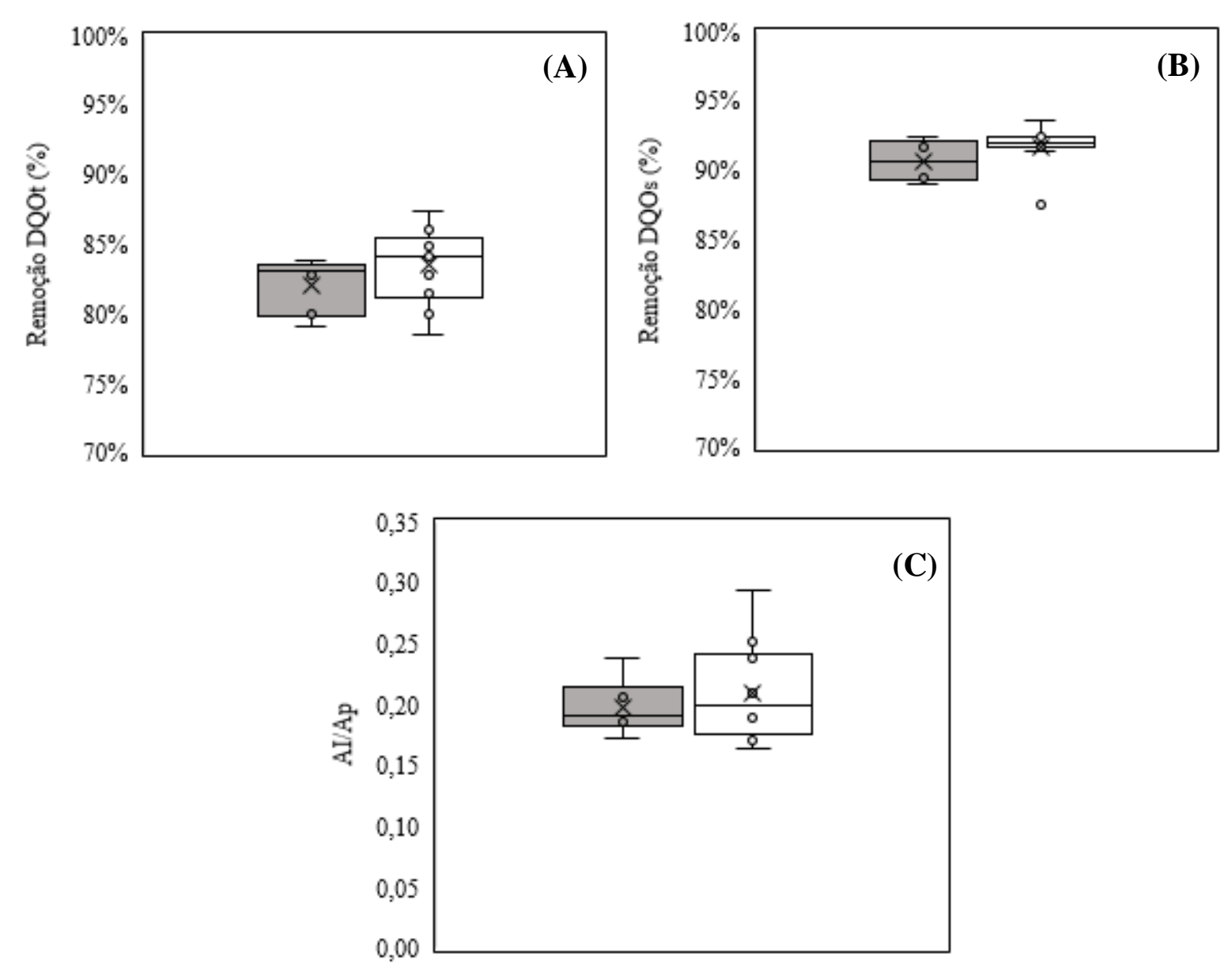

Figura 5.23 - Comparação em box-plot entre os reatores metanogênicos. (A) Eficiência de remoção de DQOt; (B) Eficiência de remoção de DQOs;(C) relação alcalinidade intermediaria e parcial AI/Ap. Legenda: ASTBR - M II ( $\square$ ) e ASTBR - M I ( $\square)$

Visualmente há pouca diferença entre esses valores, e para comprovar foi realizado análise estatística por meio do teste t de student. Para a DQOt, DQOs, CHt, AI/Ap e pH efluente a médias não apresentaram diferença significativa entre eles, entretanto para o $\mathrm{pH}$ afluente houve diferença estatística. A diferença estatística para o pH afluente ocorre devido ao tipo de alimentação, sendo o do ASTBR - M II o melaço acidificado e ASTBRM I o melaço diluído em água, sendo mais difícil a correção do pH no melaço acidificado, uma vez que há muitos ácidos para o $\mathrm{NaHCO}_{3}$ neutralizar na alimentação do $\mathrm{ASTBR}-\mathrm{M}$ II quando comparado ao reator ASTBR - M I. 
5.4.1 Comparação da produção de $\mathrm{CH}_{4}$ no sistema de duas fases e no sistema de fase única

Para as fases avaliadas dos dois reatores metanogênicos não foram detectados os gases $\mathrm{N}_{2}$ e $\mathrm{H}_{2}$ constatando que a metanogênese foi completa nos sistemas e não houve contaminação nas análises. Para o ASTBR - M II houve maior fração de $\mathrm{CH}_{4}$ quando comparada ao ASTBR - M I. As médias da composição do biogás foram $57 \pm 5 \%$ e $40 \pm$ $11 \%$, respectivamente. Enquanto que para o $\mathrm{CO}_{2}$ as médias foram de $43 \pm 5 \%$ e $60 \pm 11 \%$. A Figura 5.24 apresenta a variação da composição gasosa dos reatores. Para o sistema combinado foram avaliados 9 pontos amostrais, enquanto que para o sistema único, 12 pontos amostrais foram observados. Nota-se uma maior variação da composição gasosa no ASTBR - M I, sendo o menor valor obtido para $\mathrm{CH}_{4}$ de $22 \%$, e para o ASTBR - M II ocorreu maior estabilidade na produção desse gás, com menor valor de $52 \%$.

Avaliando as frações de $\mathrm{CH}_{4}$ para os dois reatores é possível confirmar que há diferença estatística entre as médias, uma vez que o valor encontrado para o valor-p é menor que o nível de significância $(\alpha=0,05)$. Assim, em relação a fração de $\mathrm{CH}_{4}$ o reator do sistema combinado se mostrou mais eficiente e estável.
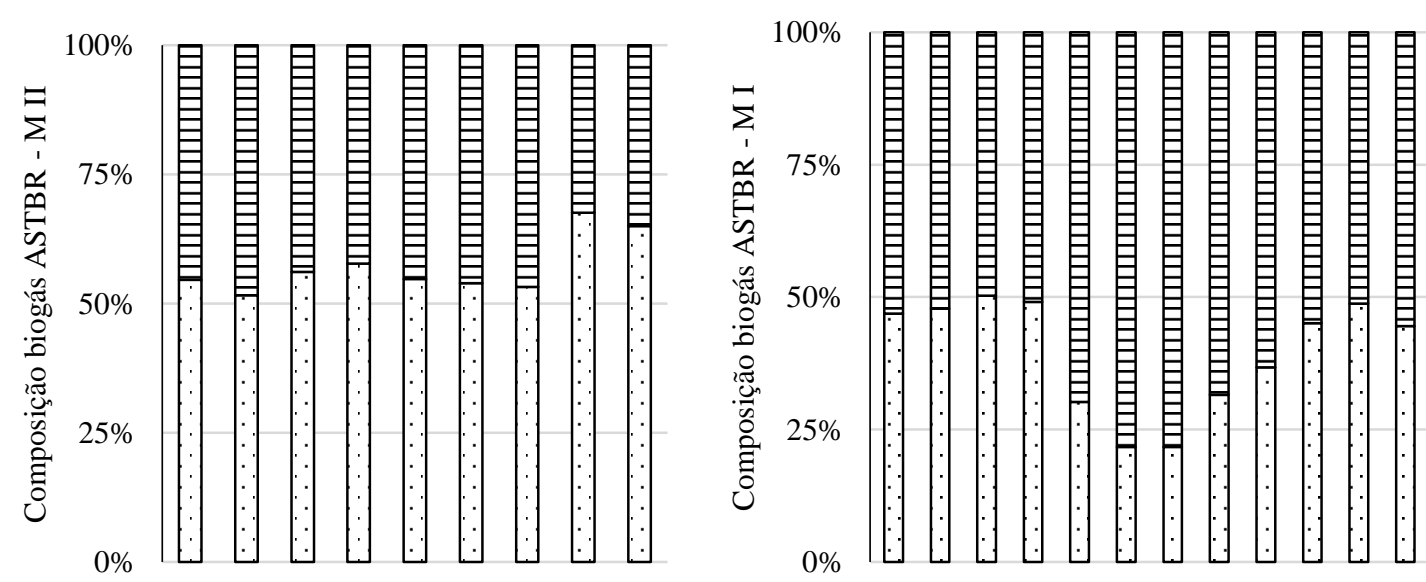

Figura 5.24 - Composição do biogás para os reatores ASTBR - M II e ASTBR - M I.

Legenda: \% $\mathrm{CH}_{4}(\square), \% \mathrm{CO}_{2}($ (घ).

Os demais parâmetros de monitoramento da produção de biogás e metano estão na Figura 5.25 comparados para os dois reatores na forma de box-plot. A vazão de biogás (Figura 5.25A), medida em $\mathrm{mL} \mathrm{h}^{-1}$, apresentou maior média para o ASTBR - M II, $411 \pm$ $95 \mathrm{~mL} \mathrm{~h}^{-1}$, enquanto o ASTBR - M I a média obtida foi de $351 \pm 84 \mathrm{~mL} \mathrm{~h}^{-1}$. Apesar das médias diferentes, estatisticamente esses valores não apresentaram diferença significativa, 
principalmente devido ao elevado desvio padrão para os dois reatores. Na Figura 5.25B são apresentadas as médias e variações para a produção volumétrica de metano (PVM), medida em $\mathrm{mLCH}_{4} \mathrm{~L}^{-1} \mathrm{~h}^{-1}$. A PVM para M II foi de $146 \pm 23 \mathrm{mLCH}_{4} \mathrm{~L}^{-1} \mathrm{~h}^{-1}$, e para M I de $88 \pm 15$ $\mathrm{mLCH}_{4} \mathrm{~L}^{-1} \mathrm{~h}^{-1}$. Observa-se uma grande variação de um sistema para o outro, sendo que o reator ASTBR - M II apresentou quase o dobro do que o ASTBR - M I. O mesmo ocorreu para a vazão molar de metano (VMM) que é apresentada na Figura 5.25C. No reator M II a média foi de $6,50 \pm 0,95 \mathrm{mmolCH}_{4} \mathrm{~h}^{-1}$, e para o M I foi de $3,50 \pm 1,41 \mathrm{mmolCH}_{4} \mathrm{~h}^{-1}$. Como consequência da variação da PVM e VMM, o rendimento de metano (MY) também foi discrepante (Figura 5.25D), sendo que para o M II foi de $375 \pm 56 \mathrm{mLCH}_{4} \mathrm{~g}^{-1} \mathrm{DQO}$, e para o M I de 208,80 \pm 64,10 $\mathrm{mLCH}_{4} \mathrm{~g}^{-1} \mathrm{DQO}$. Para os parâmetros PVM, VMM e MY é evidente o melhor desempenho do sistema combinado. Porém, como confirmação também foi realizado o teste t, obtendo para os três parâmetros diferença significativa para as médias.

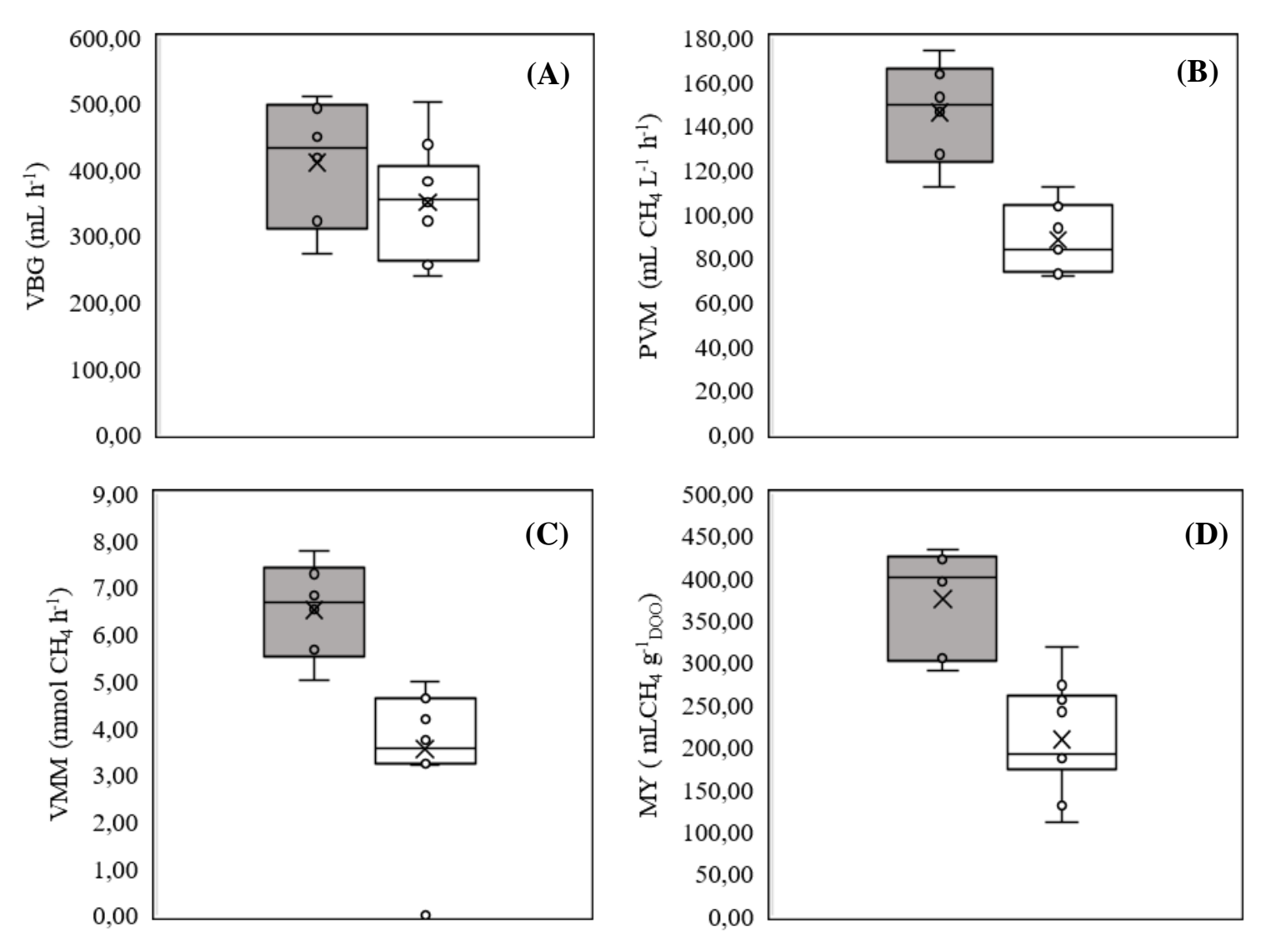

Figura 5.25 - Box-plot para comparação da produção de biogás nos reatores metanogênicos. (A) Vazão de biogás; (B) Produção volumétrica de metano; (C) Vazão molar de metano; (D) Rendimento de metano. Legenda: ASTBR - M II ( $\square)$ e ASTBR - M I ( $\square)$ 
A separação de fases é uma forma atrativa de dividir a digestão anaeróbia nas suas duas principais fases: acidogênese e metanogênse, facilitando a digestão de substratos ricos em carboidratos, fornecendo maior estabilidade para diferentes grupos de microrganismos e melhor controle do processo (DEMIREL; YENIGÜN, 2002). Outra vantagem da separação de fases é o maior rendimento de energia na forma de $\mathrm{H}_{2}$ e $\mathrm{CH}_{4}$, enquanto que no sistema de fase única, só é produzido $\mathrm{CH}_{4}$. Os sistemas de fase única apresentam como atrativo a facilidade de operação, e menores custos em relação a manutenção do sistema de tratamento. De acordo com BLONSKAJA et al. (2003) a separação de fases proporciona uma maior taxa de reação global, bem como maior rendimento de biogás. Condições semelhantes foram encontradas nesse estudo. Apesar das médias de conversão de $\mathrm{CHt}$ e remoção de DQOt e DQOs não apresentarem diferenças significativas entre elas, o rendimento de metano (MY) foi diferente, bem como a porcentagem de gás $\mathrm{CH}_{4}$ na composição gasosa. Tais parâmetros possibilitaram a conclusão do melhor desempenho global para o reator de segunda fase.

KONGJAN; O-THONG; ANGELIDAKI (2013) a partir de um reator UASB e condições semelhantes à desse estudo: temperatura de $55^{\circ} \mathrm{C}$ e $\mathrm{pH}$ efluente de 8,1 . Os autores utilizaram melaço de beterraba como substrato e a partir de uma COV de 8,3 gSV $\mathrm{L}^{-1} \mathrm{~d}^{-1}$ obtiveram uma proporção de $75 \%$ de $\mathrm{CH}_{4}$ e $25 \%$ de $\mathrm{CO}_{2}$. Um média de MY de 407 $\mathrm{mLCH}_{4} \mathrm{~g}^{-1} \mathrm{SV}$ foi obtida. FERRAZ JR. et al. (2016) também em um reator UASB de sistema combinado, tratando vinhaça de cana-de-açúcar com uma COV de 25 gDQO m $\mathrm{d}^{-}$ ${ }^{1}$ e TDH de 34 horas em condições termofílicas obteve um MY de 234,00 $\mathrm{mLCH}_{4} \mathrm{~g}^{-1} \mathrm{DQO}$. Enquanto que FUESS et al. (2017) para um sistema metanogênico alimentado com vinhaça de cana-de-açúcar acidificada obteve MY médio de $232 \mathrm{mLCH}_{4} \mathrm{~g}^{-1} \mathrm{DQO}$ para um reator UASB e $249 \mathrm{mLCH}_{4} \mathrm{~g}^{-1}$ DQO para um reator ASTBR com COV de 15 gDQO m${ }^{-3} \mathrm{~d}^{-1}$. Assim, infere-se que sistemas metanogênicos combinados com biomassa imobilizada apresentam maiores rendimento de metano.

Na Tabela 5.7 é apresentado um resumo dos principais parâmetros avaliados nessa secção para os reatores ASTBR - M II e ASTBR - M I. 
Tabela 5.7 - Comparação dos principais parâmetros entre reatores metanogênicos dos sistema combinado (ASTBR - M II) e sistema único (ASTBR - M I)

\begin{tabular}{|c|c|c|c|c|c|}
\hline & \multirow[b]{2}{*}{ Unidade } & \multicolumn{2}{|c|}{ ASTBR - M II } & \multicolumn{2}{|c|}{ ASTBR - M I } \\
\hline & & Afluente & Efluente & Afluente & Efluente \\
\hline $\mathrm{pH}$ & & $7,15 \pm 0,1$ & $8,6 \pm 0,3$ & $7,85 \pm 0,0$ & $8,6 \pm 0,2$ \\
\hline DQOt & $\mathrm{mg} \mathrm{L}^{-1}$ & $10531,0 \pm 438,0$ & $1886,0 \pm 225,0$ & $12524,0 \pm 1737,0$ & $2048,0 \pm 293,0$ \\
\hline DQOs & $\mathrm{mg} \mathrm{L}^{-1}$ & $9006,0 \pm 930,0$ & $828,0 \pm 59,0$ & $10570,0 \pm 940,0$ & $871,0 \pm 146,0$ \\
\hline DQOt & $\%$ & & $82,0 \pm 2,0$ & & $83 \pm 3,0$ \\
\hline $\mathrm{CHt}$ & $\%$ & & $97,0 \pm 0,1 \%$ & & $98,0 \pm 0,3 \%$ \\
\hline Alcalinidade intermediária & $\mathrm{mgCaCO}_{3} \mathrm{~L}^{-1}$ & $573,0 \pm 25,0$ & $423,0 \pm 93,0$ & $432,0 \pm 66,0$ & $415,0 \pm 73,0$ \\
\hline Alcalinidade parcial & $\mathrm{mgCaCO}_{3} \mathrm{~L}^{-1}$ & $1585,0 \pm 231,0$ & $2127,0 \pm 245,0$ & $2126,0 \pm 165,0$ & $1997,0 \pm 253,0$ \\
\hline $\mathrm{AI} / \mathrm{Ap}$ & & & $0,20 \pm 0,0$ & & $0,21 \pm 0,0$ \\
\hline SSV & $\mathrm{mgSSV} \mathrm{L}^{-1}$ & & $331,7 \pm 81,5$ & & $404,3 \pm 15,5$ \\
\hline$\% \mathrm{CH}_{4}$ & $\%$ & & $57,0 \pm 5,0 \%$ & & $40,0 \pm 11 \%$ \\
\hline$\% \mathrm{CO}_{2}$ & $\%$ & & $43,0 \pm 5,0 \%$ & & $60,0 \pm 11 \%$ \\
\hline VBG & $\mathrm{mL} \mathrm{h}^{-1}$ & & $411,0 \pm 95,0$ & & $351,0 \pm 84,0$ \\
\hline PVM & $\mathrm{mLCH}_{4} \mathrm{~h}^{-1}$ & & $146,0 \pm 23,0$ & & $88,0 \pm 15,0$ \\
\hline VMM & $\mathrm{mmolCH}_{4} \mathrm{~h}^{-1}$ & & $6,5 \pm 1,0$ & & $3,5 \pm 1,4$ \\
\hline MY & $\mathrm{mLCH}_{4} \mathrm{~g}^{-1} \mathrm{DQO}$ & & $375,4 \pm 62,0$ & & $209,0 \pm 64,0$ \\
\hline
\end{tabular}


5.4.2 Apresentação das estruturas microbiológicas nos reatores metanogênicos de segunda fase e de fase única ao final da operação de cada sistema

Foram avaliadas amostras da biomassa suspensa e aderidas retiradas ao final de cada operação. Assim, a biomassa do reator ASTBR - M II foi retirada com COV de $10 \mathrm{~g}$ $\mathrm{L}^{-1} \mathrm{~d}^{-1}$, TDH de 24 horas e $1 \mathrm{gNaHCO}_{3} \mathrm{~g}^{-1}$ DQO. E a biomassa do reator ASTBR - M I apresentava COV de 10,0 $\mathrm{g} \mathrm{L}^{-1} \mathrm{~d}^{-1}$, TDH de 28 horas e 1,00 $\mathrm{gNaHCO}_{3} \mathrm{~g}^{-1} \mathrm{DQO}$, porém havia passado por um período de instabilidade (acidificação do sistema) e ainda estava se recuperando.

Para a biomassa suspensa do reator ASTBR - M II a concentração de sólidos medidos na forma de SSV foi de $0,725 \mathrm{gSSV} \mathrm{L}^{-1}$, não detendo dados dos sólidos da biomassa aderida para esse sistema. No reator ASTBR - M I a concentração de sólidos voláteis na biomassa suspensa foi de $5,80 \mathrm{gSSV} \mathrm{L}^{-1}$ e $10,50 \mathrm{gSSV} \mathrm{L}^{-1}$ para a biomassa aderida. Os sólidos voláteis dizem respeito a matéria orgânica existente no meio, e a discrepância dos valores se deve a instabilidade que o reator ASTBR - M I encontrava-se quando foi retirada a biomassa.

A Figura 5.26 A é uma imagem da espuma de poliuretano com a biomassa aderida, enquanto que a Figura 5.26 B representa o liquido drenado do reator com a biomassa suspensa.

(A)

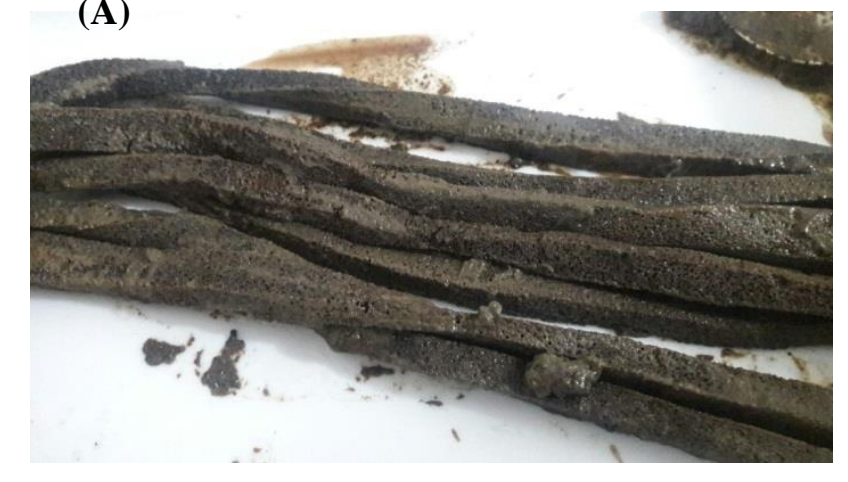

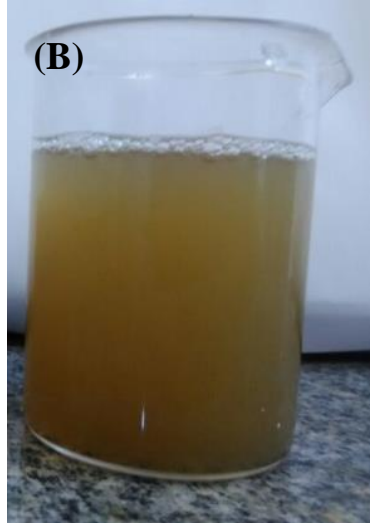

Figura 5.26 - (A) Biomassa aderida ao material suporte do reator metanogênico; (B) biomassa suspensa do reator metanogênico

Para verificação das comunidades microbiológicas dos reatores metanogênicos foi utilizada a Eletroforese em gel com gradiente desnaturante (DGGE). Os principais índices aplicados avaliados foram a dominância (D) e índice de Shannon (H). A dominância varia 
de 0 a 1, sendo que valores baixos significam que há dominância de diversos táxons no sistema, enquanto que D próxima a 1 significa que há um táxon principal. Já o índice de Shannon $(\mathrm{H})$ mede a diversidade dos microrganismos no sistema. Quanto maior o valor de $\mathrm{H}$, maior a diversidade de bactérias ou arqueias na biomassa. $\mathrm{O}$ dendograma refere-se aos perfis de banda do DGGE e fornece o coeficiente de similaridade entre as amostras.

A Figura 5.27 apresenta o dendograma para o domínio Bacteria. O coeficiente de similaridade entre a amostra biomassa aderida (\#1b) e suspensa (\#2b) do reator ASTBR M II foi de 96,5\%, enquanto que a as amostras da biomassa aderida (\#3b) e suspensa (\#4b) do reator ASTBR - M I a similaridade foi de $84 \%$. O coeficiente de similaridade entre todas as amostras dos dois reatores foi de $72 \%$ para as bactérias.

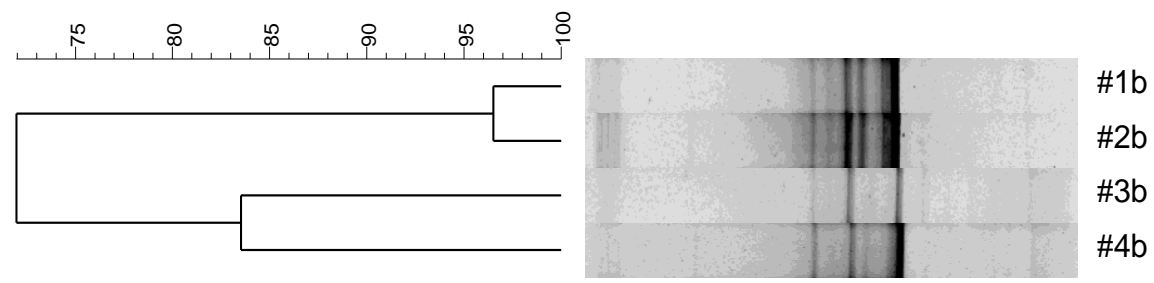

Figura 5.27 - Dendograma do domínio Bacteria para os reatores ASTBR - M I e ASTBR - M II

Os valores de dominância do domínio Bacteria (Tabela 5.8) para o reator ASTBR M II foram semelhantes, de 0,10 para a amostra \#1b e 0,11 para a amostra \#2b. O índice de Shannon também apresentou pouca variação entre as amostras desse reator, 2,20 amostra \#1b e 2,30 amostra \#2b. O índice D para o reator do sistema único (ASTBR - M I) foi maior do que o sistema combinado, sendo de 0,25 para a amostra \#3b e 0,22 para amostra \#4b. Entretanto, o índice de Shannon foi menor, 1,70 e 1,85, respectivamente. No reator M I há menos populações, quando comparado ao M II, uma vez que maior índice de Shannon foi maior em M II em relação a M I, o que era esperado, uma vez que o ASTBR- M II além das bactérias do próprio reator provavelmente ocorreu a entrada de bactérias alóctones do reator acidogênico. Já no reator M I, observou-se menor diversidade bacteriana, porém maior dominância, indicando o favorecimento de bactérias especialistas na degradação do substrato.

Tabela 5.8 - Índice de dominância (D) e Shannon (H) para o domínio Bacteria

\begin{tabular}{ccccc}
\hline $\begin{array}{c}\text { Indicies } \\
\text { Aplicados }\end{array}$ & $\begin{array}{c}\text { ASTBR - M II } \\
\text { aderida (\#1b) }\end{array}$ & $\begin{array}{c}\text { ASTBR - M II } \\
\text { Suspensa (\#2b) }\end{array}$ & $\begin{array}{c}\text { ASTBR - M I } \\
\text { aderida (\#3b) }\end{array}$ & $\begin{array}{c}\text { ASTBR - M I } \\
\text { Suspensa (\#4b) }\end{array}$ \\
\hline Dominância (D) & 0,10 & 0,11 & 0,25 & 0,22 \\
\hline Shannon (H) & 2,20 & 2,30 & 1,70 & 1,85 \\
\hline
\end{tabular}


A maior dominância de bactérias nas amostras \#3b e \#4b corroboram que houve desestabilização do sistema logo após a retirada total do bicarbonato, ocasionando modificações nas populações bacterianas resultando na acidificação do sistema, bem como na produção de $\mathrm{H}_{2}$ nesse período.

A Figura 5.28 representa o dendograma para o domínio Archaea. O coeficiente de similaridade entre as amostras aderida (\#1a) e suspensa (\#2a) do reator ASTBR - M II foi de $77 \%$. E a similaridade entre as amostras aderida (\#3a) e suspensa (\#4a) do reator ASTBR - M I foi de 75\%. Já a similaridade entre todas as amostras para o domínio Archaea é de $48 \%$. Nota-se que a similaridade desse domínio entre as amostras do mesmo reator é elevada, entretanto quando a comparação entre as quatro amostras é realizada, a similaridade é baixa. Demonstrando que há grande diferença entre os sistemas.

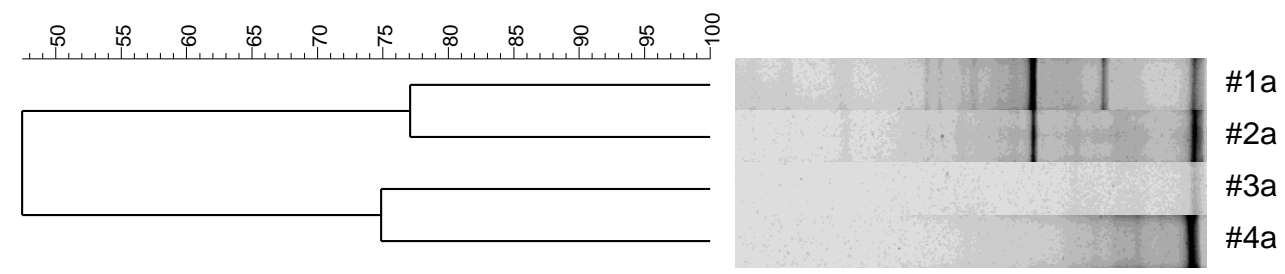

Figura 5.28 - Dendograma do domínio Archaea para os reatores ASTBR - M II e ASTBR - M I

Os índices de dominância e Shannon para o domínio Archaea estão na Tabela 5.9. Comparando a dominância para as amostras \#1a de 0,20 e \#2a de 0,32 observa-se que há maior dominância de arqueias na biomassa suspensa. Na amostra \#3a a dominância do domínio Archaea é de 0,95, indicando que há dominância de algumas populações de arqueias. E a dominância da amostra suspensa (\#4a) é de 0,43, não sendo tão elevada quanto na amostra \#3a, mas é alta quando comparada com as amostras \#1a e \#2a.

Já o índice de Shannon, nas amostras \#1a e \#2a são de 1,98 e 1,45. E para as amostras \#3a e \#4a de 0,12 e 1,20. Esses valores indicam que em todas amostras, exceto a \#3a, há uma considerável diversidade desse domínio. Em contrapartida a diversidade do domínio Archaea é baixa para a amostra aderida. Esses resultados apoiam a hipótese gerada no item 5.3.2, que após a acidificação do sistema a metanogênese se reestabeleceu por meio das arqueias metanogênicas hidrogenotróficas. A elevada dominância e baixa diversidade indicam que há populações especificas predominando no sistema. $\mathrm{O}$ fato da biomassa ter sido retirada do reator ASTR - M I quando o sistema estava recuperando a capacidade de produção de metano auxiliou na elevada dominância obtida na biomassa 
aderida e baixa dominância na biomassa suspensa. Pois se a biomassa tivesse sido retirada durante um período de estabilidade, possivelmente outras populações teriam se restabelecido, diminuindo o valor da dominância e aumentando a diversidade, como obtido para a amostra aderida do reator ASTBR - M II (\#1a).

Tabela 5.9 - Índice de dominância (D) e Shannon (H) para o domínio Archaea

\begin{tabular}{ccccc}
\hline $\begin{array}{c}\text { Indicies } \\
\text { Aplicados }\end{array}$ & $\begin{array}{c}\text { ASTBR - M II } \\
\text { aderida (\#1a) }\end{array}$ & $\begin{array}{c}\text { ASTBR - M II } \\
\text { Suspensa (\#2a) }\end{array}$ & $\begin{array}{c}\text { ASTBR - M I } \\
\text { aderida (\#3a) }\end{array}$ & $\begin{array}{c}\text { ASTBR - M I } \\
\text { Suspensa (\#4a) }\end{array}$ \\
\hline Dominância (D) & 0,20 & 0,32 & 0,95 & 0,43 \\
\hline Shannon (H) & 1,98 & 1,45 & 0,12 & 1,20 \\
\hline
\end{tabular}

\subsubsection{Balanço energético}

Como ressaltado ao longo deste trabalho, os gases produzidos durante a digestão anaeróbia nos sistemas de duas fases $\left(\mathrm{H}_{2}\right.$ e $\left.\mathrm{CH}_{4}\right)$ e de fase única $\left(\mathrm{CH}_{4}\right)$ apresentam potencial energético, sendo mais uma fonte de energia renovável. Com objetivo de avaliar o potencial energético dos reatores utilizados foi realizado um balanço energético levando em consideração os parâmetros de DQOaf, \%DQO e MY para os reatores metanogênicos, e CHaf, \%CH, e HY para o sistema acidogênico.

Na Figura 5.29 são apresentados os balanços energéticos para os dois sistemas avaliados. Para fins de comparação, assim como no item 5.4.1, foram comparadas condições semelhantes para os reatores ASTBR - M II e ASTBR - M I, fases VIII e III, respectivamente. Os valores de potencial energético (EP) foram calculados em $\mathrm{KJ} \mathrm{L}^{-1} \mathrm{e}$ convertidos para $\mathrm{KJ} \mathrm{g}^{-1}$ melaço de acordo com a massa inicial de melaço utilizada na alimentação dos reatores.

Do ponto de vista energético no sistema de duas fases (Figura 5.29 A) o reator ASTBR-A obteve rendimento de $\mathrm{H}_{2}$ de $1,18 \mathrm{molH}_{2} \mathrm{~mol}^{-1} \mathrm{CH}$, o que de acordo com a eficiência de conversão de carboidratos e o poder calorífico desse gás representam um potencial energético (EP2) de $0,251 \mathrm{KJ} \mathrm{g}^{-1}$ melaço. No reator ASTBR- M II, para a fase avaliada, foi obtido rendimento de $\mathrm{CH}_{4}$ de $375 \mathrm{mLCH}_{4} \mathrm{gDQO}^{-1}$, com respectivo potencial energético de 11,60 $\mathrm{KJ} \mathrm{g}^{-1}$ melaço. Assim, o EP2 total do sistema foi de $11,85 \mathrm{KJ} \mathrm{g}^{-1}$ melaço.

Para o sistema de fase única (Figura 5.29 B) o valor energético baseou-se apenas na produção de $\mathrm{CH}_{4}$ uma vez que para a fase avaliada não foi detectado hidrogênio no 
sistema. O rendimento de $\mathrm{CH}_{4}$ foi de $209 \mathrm{mLCH}_{4} \mathrm{~g}_{\mathrm{DQO}}{ }^{-1}$, correspondendo a um EP2 total de $6,50 \mathrm{KJ} \mathrm{g}^{-1}$ melaço.

(A)

Sistema de duas fases

Potencial energético total EPt: $11,85 \mathrm{KJ} \mathrm{g}^{-1}$ melaço

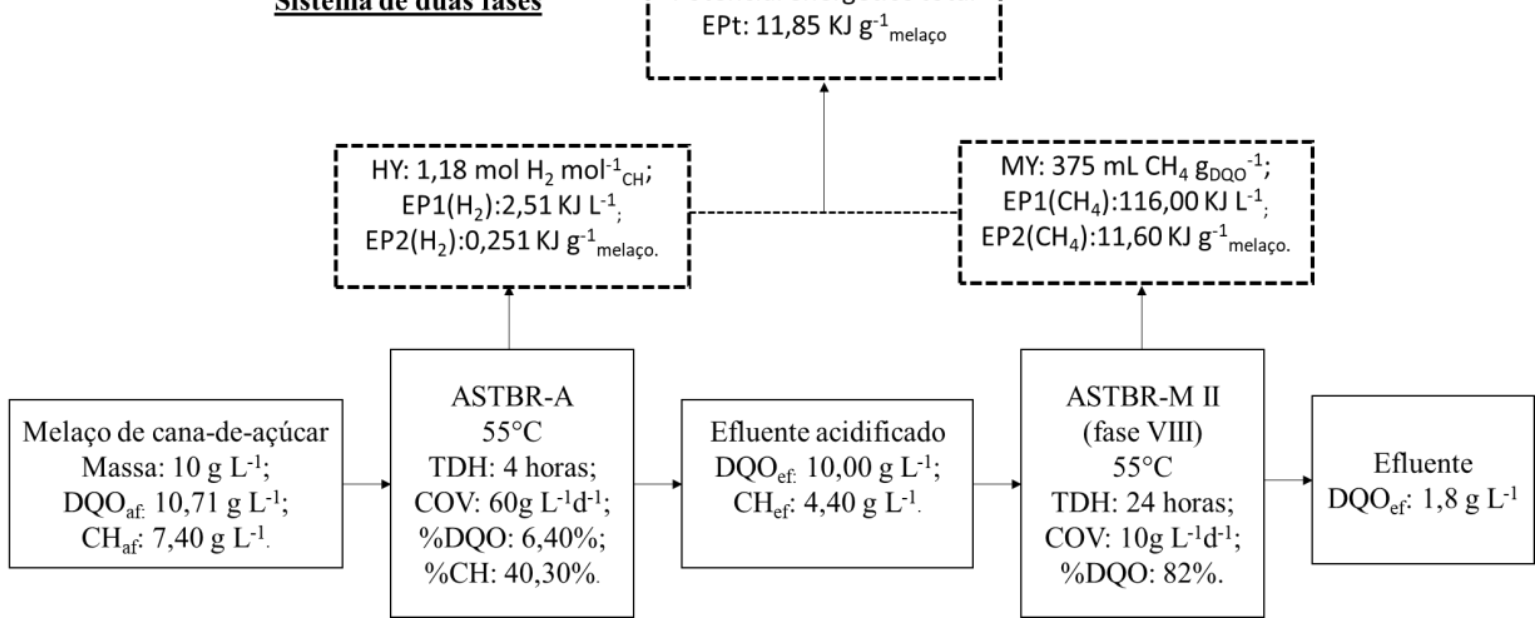

(B)

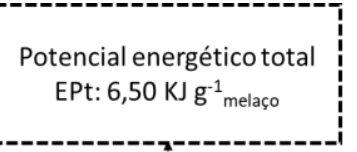

Sistema de fase única

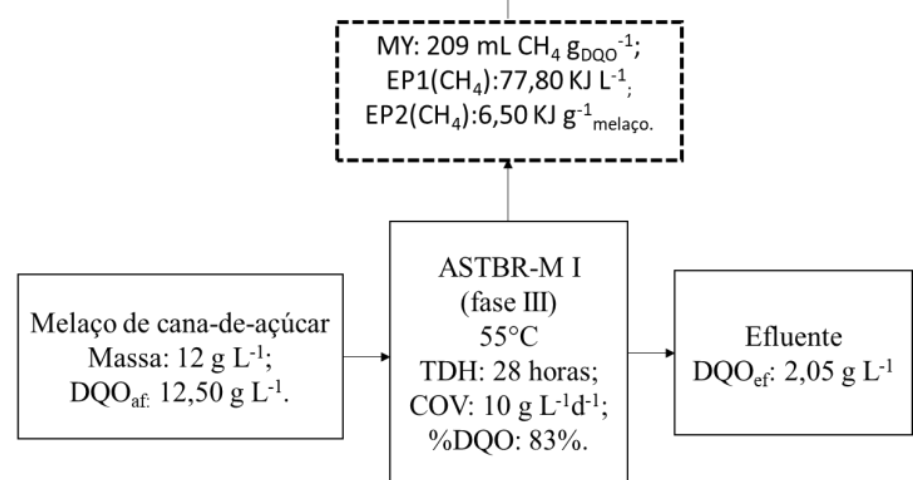

Figura 5.29 - Balanço energético a partir dos parâmetros de desempenho dos reatores ASTBR-A, ASTBR-M II e ASTBR- M I. (A) Potencial energético para o sistema de duas fases; (B) Potencial energético para sistema de fase única

Apesar dos subprodutos da produção de álcool e açúcar como o bagaço e a vinhaça serem utilizados como fonte de energia em algumas usinas do país, o substrato utilizado neste trabalho, o melaço de cana-de-açúcar, apresenta potencial para ser utilizado como mais uma fonte de energia nas usinas do setor suco energético. 


\section{CONCLUSÕES}

- A produção de hidrogênio se manteve continua durante 392 dias de operação do reator ASTBR - A, com a COV de 60,00 $\mathrm{g} \mathrm{L}^{-1} \mathrm{~d}^{-1}$ e $\mathrm{pH}$ efluente de 3,80. A PVH média foi de $88,00 \mathrm{~mL} \mathrm{H}_{2} \mathrm{~L}^{-1} \mathrm{~h}^{-1}$, enquanto que o $\mathrm{HY}$ médio foi de $1,18 \mathrm{~mol} \mathrm{H}_{2}$ mol $\mathrm{CH}^{-1}$. A principal rota metabólica encontrada no sistema acidogênico foi a do ácido lático e acético gerando ácido butírico e $\mathrm{H}_{2}$. $\mathrm{O}$ principal gênero identificado com a produção de $\mathrm{H}_{2}$ foi o Thermoanaerobacterium, apesar de não ser comprovada a relação desse gênero com a principal rota do sistema. Destaca-se que a estratégia utilizada foi adequada para a manutenção de reator acidogênico com produção de $\mathrm{H}_{2}$;

- O reator metanogênico do sistema de duas fases (ASTBR - M II) sofreu grande instabilidade até a Fase Va. O retorno de COV menores, como estratégia operacional, foi relevante para recuperação do sistema. A eficiência de remoção de DQOt atingiu 84\%. A maior média de MY foi de 375,00 $\mathrm{mLCH}_{4} \mathrm{gDQO}^{-1}$, observada com COV 10,00 $\mathrm{g} \mathrm{L}^{-1} \mathrm{~d}^{-1}$ e TDH $24 \mathrm{~h}$;

- O reator metanogênico de fase única (ASTBR - M I) teve operação estável enquanto a concentração de $\mathrm{NaHCO}_{3}$ foi de 1,00 a $0,25 \mathrm{gNaHCO}_{3} \mathrm{~g}^{-1} \mathrm{DQO}$. A maior média de MY foi de 292,10 $\mathrm{mLCH}_{4} \mathrm{gDQO}^{-1}$, com COV de 10,00 $\mathrm{g} \mathrm{L}^{-1} \mathrm{~d}^{-1} \mathrm{e}$ $0,25 \mathrm{gNaHCO}_{3} \mathrm{~g}^{-1} \mathrm{DQO}$. Após a retirada total de $\mathrm{NaHCO}_{3}$ o sistema de fase única sofreu acidificação. As estratégias de recuperação com aumento da dosagem de álcali e manutenção das cargas permitiram observar produção de metano, porém o período de tempo disponível não foi suficiente para a recuperação da estabilidade do sistema;

- Na comparação dos reatores metanogênicos do sistema de duas fases (ASTBR - M II) e fase única (ASTBR - M I), com bases em análise estatística, conclui-se que em relação a remoção de matéria orgânica e carboidratos não houve diferença entre os dois sistemas. Em relação ao rendimento de metano o reator metanogênico de segunda fase foi $44 \%$ superior ao observado no metanogênico de fase única. 


\section{REFERÊNCIAS BIBLIOGRÁFICAS}

ADORNO, M. A. T.; HIRASAWA, J. S.; VARESCHE, M. B. A. Development and Validation of Two Methods to Quantify Volatile Acids (C2-C6) by GC/FID: Headspace (Automatic and Manual) and Liquid-Liquid Extraction (LLE). American Journal of Analytical Chemistry, v. 5, n. 7, p. 406-414, 6 maio 2014.

ALBANEZ, R. Codigestão de vinhaça e melaço em biorreator anaeróbio em bateladas sequenciais com biomassa imobilizada visando a produção de hidrogênio. Tese (doutorado). Escola de Engenharia de São Carlos. Universidade de São Paulo, 2015.

AMANI, T. et al. Study of microbiological and operational parameters in thermophilic syntrophic degradation of volatile fatty acids in an upflow anaerobic sludge blanket reactor. Journal of Environmental Chemical Engineering, v. 3, n. 1, p. 507-514, 2015.

ANEEL. Matriz de energia elétrica. Disponível em: <http://www2.aneel.gov.br/aplicacoes/capacidadebrasil/OperacaoCapacidadeBrasil.cfm>. Acesso em: $26 \mathrm{dez} .2016$.

APHA. Standard Methods for Examination of Water and Wastewater. 19. ed. Washington, DC, USA.: American Public Health Association/ American Water Works Association/ Water Environmental Federation, 2005.

BARBOSA, M. Y. U. Reator anaeróbio com vinhaça de cana-de-açúcar: avaliação dos efeitos causados pela interrupção na alimentação e estratégias para mitigação. Dissertação (mestrado).Escola de Engenharia de São Carlos. Universidade de São Paulo, 2017.

BARROS, V. G. Conversão anaeróbia de vinhaça e melaço em reatores uasb inoculados com lodo granulado. Dissertação (Mestrado em microbiologia agropecuária) Faculdade de Ciências Agrárias e Veterinárias - UNESP - Campus Jaboticabal, p. 69 p., 2013.

BLONSKAJA, V.; MENERT, A.; VILU, R. Use of two-stage anaerobic treatment for distillery waste. Advances in Environmental Research, v. 7, n. 3, p. 671-678, 2003.

BLUNDI, S.F., GADÊLHA, R. F. Método para determinação de matérias orgãnica especifica em águas residuárias. In: Chenicharo, C.A.L. (Coord.). Pós tratamento de 
efluentes de reatores anaeróbios: aspectos metodológicos. 2001. p. 9-17.

BONCZ, M. A. et al. Application of urea dosing for alkalinity supply during anaerobic digestion of vinasse. Water Science and Technology, v. 66, n. 11, p. 2453-2460, 2012.

BRASIL. Resolução n 8 , 30 de Janeiro de 2015 da Agência Nacional do Petróleo Gás Natural e Biocombustíveis/ANP. Diário Oficial da República Federativa do Brasil. Brasil, DF, n ${ }^{\circ}, 02$ de fevereiro de 2015. Seção 1, p. 101.

CÄMMERER, B.; KROH, L. Investigation of the influence of reaction conditions on the elementary composition of food melanoidins. Food Chemistry, v. 53, n. 53, p. 55-59, 1995.

CAPORASO, J. G. et al. QIIME allows analysis of high-throughput community sequencing data. Nature methods, v. 7, n. 5, p. 335-6, 2010.

CHANG, J. J. et al. Molecular monitoring of microbes in a continuous hydrogen-producing system with different hydraulic retention time. International Journal of Hydrogen Energy, v. 33, n. 5, p. 1579-1585, 2008.

CHENG, H. H. et al. Biological hydrogen and methane production from bagasse bioethanol fermentation residues using a two-stage bioprocess. Bioresource Technology, v. 210, n. 2016, p. 49-55, 2016.

COLE, J. R. et al. Ribosomal Database Project: Data and tools for high throughput rRNA analysis. Nucleic Acids Research, v. 42, n. D1, 2014.

CONAB. Perfil do Setor do Açúcar e do Etanol no Brasil - safra 2010/2011. Brasilia, DF. p.64, 2013.

CONAB. Acompanhamento da safra brasiliera de cana-de-açúcar: v.3. Brasilia, DF. p.78. 2016.

DAHIYA, J.; SINGH, D.; NIGAM, P. Decolourisation of molasses wastewater by cells of Pseudomonas fluorescens immobilised on porous cellulose carrier. Bioresource Technology, v. 78, n. 1, p. 111-114, 2001.

DE VRIEZE, J. et al. High salinity in molasses wastewaters shifts anaerobic digestion to carboxylate production. Water Research, v. 98, p. 293-301, 2016. 
DEMIREL, B.; YENIGÜN, O. Two-phase anaerobic digestion processes: A review. Journal of Chemical Technology and Biotechnology, v. 77, n. 7, p. 743-755, 2002.

DESANTIS, T. Z. et al. Greengenes, a Chimera-Checked 16S rRNA Gene Database and Workbench Compatible with ARB. Applied and Environmental Microbiology, v. 72, n. 7, p. 5069-5072, 1 jul. 2006.

DIEZ-GONZALEZ, F.; RUSSELL, J. B.; HUNTER, J. B. The role of an NADindependent lactate dehydrogenase and acetate in the utilization of lactate by Clostridium acetobutylicum strain P262. Archives of Microbiology, v. 164, n. 1, p. 36-42, 1995.

DILALLO, R. \& ALBERTSON, O. R. Volatile àcids by Direct Titration. Journal Water Pollution Control Federation, v. 23, n. 4, p. 353-365, 1961.

DOLL, M. M. R.; FORESTI, E. Effect of the sodium bicarbonate in the treatment of vinasse in AnSBBR operated at 55 and 35 degrees C. Engenharia Sanitaria E Ambiental, v. 15, n. 3, p. 275-282, 2010.

DUBOIS, M. et al. Colorimetric Method for Determination of Sugars and Related Substances. Analytical Chemistry, v. 28, n. 3, p. 350-356, 1 mar. 1956.

EDGAR, R. C. Search and clustering orders of magnitude faster than BLAST. Bioinformatics, v. 26, n. 19, p. 2460-2461, 1 out. 2010.

FANG, C.; BOE, K.; ANGELIDAKI, I. Anaerobic co-digestion of by-products from sugar production with cow manure. Water Research, v. 45, n. 11, p. 3473-3480, 2011.

FELTRIN, V. P. et al. Produção de Lactobacillus plantarum em Melaço de. Brazilian Archives of Biology and Technology, v. 43, n. 1, 2000.

FERNANDES, B. S. et al. Potential to produce biohydrogen from various wastewaters. Energy for Sustainable Development, v. 14, n. 2, p. 143-148, 2010.

FERRAZ JR., A. D. N. Digestão anaeróbia da vinhaça da cana de açúcar em reator acidogênico de leito fixo seguido de reator metanogênico de manta de lodo. Tese (doutorado). Universidade de São Paulo. Escola de Engenharia de São Carlos, 2013.

FERRAZ JR., A. D. N. et al. Effect of organic loading rate on hydrogen production from sugarcane vinasse in thermophilic acidogenic packed bed reactors. International Journal of Hydrogen Energy, v. 39, n. 30, p. 16852-16862, 2014. 
FERRAZ JR., A. D. N. et al. Thermophilic anaerobic digestion of raw sugarcane vinasse. Renewable Energy, v. 89, p. 245-252, 2016.

FERRAZ JR., A. D. N.; ETCHEBEHERE, C.; ZAIAT, M. High organic loading rate on thermophilic hydrogen production and metagenomic study at an anaerobic packed-bed reactor treating a residual liquid stream of a Brazilian biorefinery. Bioresource Technology, v. 186, p. 81-88, 2015.

FERRAZ JR, A. D. N. et al. Impact of organic loading rate on biohydrogen production in an up-flow anaerobic packed bed reactor (UAnPBR). Bioresource Technology, v. 164, p. 371-379, 2014.

FGV ENERGIA. BIO combustíveis. Rio de Janeiro, n8, ano 4, p.120, 2017.

FUESS, L. T. et al. Operational strategies for long-term biohydrogen production from sugarcane stillage in a continuous acidogenic packed-bed reactor. International Journal of Hydrogen Energy, v. 41, n. 19, p. 8132-8145, 2016.

FUESS, L. T. et al. Thermophilic two-phase anaerobic digestion using an innovative fixedbed reactor for enhanced organic matter removal and bioenergy recovery from sugarcane vinasse. Applied Energy, v. 189, p. 480-491, 2017.

FUESS, L. T. Biodigestão anaeróbia termofílica de vinhaça em sistemas combinados do tipo acidogênico-metanogênico para potencialização da recuperação de bioenergia em biorrefinarias de cana-de-açúcar de primeira geração. Tese (doutorado). Escola de Engenharia de São Carlos. Universidade de São Paulo, 2017.

FUESS, L. T. et al. Temporal dynamics and metabolic correlation between lactateproducing and hydrogen-producing bacteria in sugarcane vinasse dark fermentation: The key role of lactate. Bioresource Technology, v. 247, n. July 2017, p. 426-433, 2018.

GIORDANO, A.; CANTÙ, C.; SPAGNI, A. Monitoring the biochemical hydrogen and methane potential of the two-stage dark-fermentative process. Bioresource Technology, v. 102, n. 6, p. 4474-4479, 2011.

GOES, T.; MARRA, R.; SILVA, G. S. E. Setor sucroalcooleiro no Brasil Situação atual e perspectivas. Revista da Política Agrícola, p. 39-51, 2008.

GOMES, P. C. F. L. et al. Rapid determination of 12 antibiotics and caffeine in sewage and 
bioreactor effluent by online column-switching liquid chromatography / tandem mass spectrometry. p. 8787-8801, 2015.

GRIFFITHS, R. I.; WHITELEY, A. S.; O'DONNELL, A. G. Rapid method for coextraction of DNA and RNA from natural environments for analysis of ribosomal DNAand rRNA-based microbial community composition. Applied and Environmental Microbiology, v. 66, p. 5488-5491, 2000.

GUO, W. Q. et al. Biohydrogen production from ethanol-type fermentation of molasses in an expanded granular sludge bed (EGSB) reactor. International Journal of Hydrogen Energy, v. 33, n. 19, p. 4981-4988, 2008.

GUO, X. M. et al. Predictive and explicative models of fermentative hydrogen production from solid organic waste: Role of butyrate and lactate pathways. International Journal of Hydrogen Energy, v. 39, n. 14, p. 7476-7485, 2014.

HAFEZ, H. et al. Effect of organic loading on a novel hydrogen bioreactor. International Journal of Hydrogen Energy, v. 35, n. 1, p. 81-92, 2010.

HALLENBECK, P. C.; BENEMANN, J. R. Biological hydrogen production; Fundamentals and limiting processes. International Journal of Hydrogen Energy, v. 27, n. 11-12, p. 1185-1193, 2002.

HAN, W. et al. Fermentative hydrogen production from molasses wastewater in a continuous mixed immobilized sludge reactor. Bioresource Technology, v. 110, p. 219$223,2012$.

HAO, L. P. et al. Shift of pathways during initiation of thermophilic methanogenesis at different initial pH. Bioresource Technology, v. 126, p. 418-424, 2012.

HARPER, S. R.; POHLAND, F. G. Recent developments in hydrogen management during anaerobic biological wastewater treatment. Biotechnology and Bioengineering, v. 28, n. 4, p. 585-602, 1986.

HAWKES, F. R. et al. Sustainable fermentative hydrogen production: Challenges for process optimisation. International Journal of Hydrogen Energy, v. 27, n. 11-12, p. 1339-1347, 2002.

HORIUCHI, J. I. et al. Selective production of organic acids in anaerobic acid reactor by 
pH control. Bioresource Technology, v. 82, n. 3, p. 209-213, 2002.

HUNG, C. H. et al. Interactions between Clostridium sp. and other facultative anaerobes in a self-formed granular sludge hydrogen-producing bioreactor. International Journal of Hydrogen Energy, v. 36, n. 14, p. 8704-8711, 2011.

JHA, P.; SCHMIDT, S. Reappraisal of chemical interference in anaerobic digestion processes. Renewable and Sustainable Energy Reviews, v. 75, n. November, p. 954971, 2017.

KAPDAN, I. K.; KARGI, F. Bio-hydrogen production from waste materials. Enzyme and Microbial Technology, v. 38, n. 5, p. 569-582, 2006.

KAUSHIK, A. et al. Activated carbon from sugarcane bagasse ash for melanoidins recovery. Journal of Environmental Management, v. 200, p. 29-34, 2017.

KESKIN, T.; GIUSTI, L.; AZBAR, N. Continuous biohydrogen production in immobilized biofilm system versus suspended cell culture. International Journal of Hydrogen Energy, v. 37, n. 2, p. 1418-1424, 2012.

KESKIN, T.; HALLENBECK, P. C. Hydrogen production from sugar industry wastes using single-stage photofermentation. Bioresource Technology, v. 112, p. 131-136, 2012.

KHANAL, S. K. et al. Biological hydrogen production: Effects of $\mathrm{pH}$ and intermediate products. International Journal of Hydrogen Energy, v. 29, n. 11, p. 1123-1131, 2004.

KhONGKLIANG, P.; KOnGJAN, P.; O-THONG, S. Hydrogen and Methane Production from Starch Processing Wastewater by Thermophilic Two-Stage Anaerobic Digestion. [s.1.] Elsevier B.V., 2015. v. 79

KIM, M.; AHN, Y. H.; SPEECE, R. E. Comparative process stability and efficiency of anaerobic digestion; mesophilic vs. thermophilic. Water Research, v. 36, n. 17, p. 43694385, 2002.

KIM, T. H. et al. Effects of initial lactic acid concentration, HRTs, and OLRs on biohydrogen production from lactate-type fermentation. Bioresource Technology, v. 103, n. 1, p. 136-141, 2012.

KONGJAN, P.; ANGELIDAKI, I. Extreme thermophilic biohydrogen production from wheat straw hydrolysate using mixed culture fermentation: Effect of reactor configuration. 
Bioresource Technology, v. 101, n. 20, p. 7789-7796, 2010.

KONGJAN, P.; O-THONG, S.; ANGELIDAKI, I. Biohydrogen production from desugared molasses (DM) using thermophilic mixed cultures immobilized on heat treated anaerobic sludge granules. International Journal of Hydrogen Energy, v. 36, n. 21, p. 14261-14269, 2011a.

KONGJAN, P.; O-THONG, S.; ANGELIDAKI, I. Performance and microbial community analysis of two-stage process with extreme thermophilic hydrogen and thermophilic methane production from hydrolysate in UASB reactors. Bioresource Technology, v. 102, n. 5 , p. 4028-4035, 2011 b.

KONGJAN, P.; O-THONG, S.; ANGELIDAKI, I. Hydrogen and methane production from desugared molasses using a two-stage thermophilic anaerobic process. Engineering in Life Sciences, v. 13, n. 2, p. 118-125, 2013.

KUMARI, S.; KUMAR, R.; MANICKAM, N. Improved polycyclic aromatic hydrocarbon degradation in a crude oil by individual and a consortium of bacteria. Bioresource Technology, v. 254, n. November 2017, p. 1-26, 2018.

KURODA, K. et al. High organic loading treatment for industrial molasses wastewater and microbial community shifts corresponding to system development. Bioresource Technology, v. 196, p. 225-234, 2015.

LEE, J. Y. et al. Two-stage biogas production by co-digesting molasses wastewater and sewage sludge. Bioprocess and Biosystems Engineering, v. 37, n. 12, p. 2401-2413, 2015.

LI, J. et al. Hydrogen production from diluted molasses by anaerobic hydrogen producing bacteria in an anaerobic baffled reactor (ABR). International Journal of Hydrogen Energy, v. 32, n. 15 SPEC. ISS., p. 3274-3283, 2007.

LIN, C. Y. et al. Fermentative hydrogen production from wastewaters: A review and prognosis. International Journal of Hydrogen Energy, v. 37, n. 20, p. 15632-15642, 2012.

LIN, Y. et al. Influence of bicarbonate buffer on the methanogenetic pathway during thermophilic anaerobic digestion. Bioresource Technology, v. 137, p. 245-253, 2013. 
LIU, D. et al. Hydrogen and methane production from household solid waste in the twostage fermentation process. Water Research, v. 40, n. 11, p. 2230-2236, 2006.

MARIAKAKIS, I.; MEYER, C.; STEINMETZ, H. Fermentative Hydrogen Production by Molasses; Effect of Hydraulic Retention Time, Organic Loading Rate and Microbial Dynamics. In: Hydrogen Energy - Challenges and Perspectives. Intech - Open science and open minds, c.5, p. 29, 2012.

MARTINS, M. S.; KITTINYA, J.; OJIJO, O. V. A kinetic model for the glucose/glycine Millard reaction pathways. Food Chemistry, v. 90, n. 1-2, p. 257-269, 2011.

MATSUMOTO, M.; NISHIMURA, Y. Hydrogen production by fermentation using acetic acid and lactic acid. Journal of Bioscience and Bioengineering, v. 103, n. 3, p. 236-241, 2007.

MENG, X. et al. Methane production and characteristics of the microbial community in a two-stage fixed-bed anaerobic reactor using molasses. Bioresource Technology, v. 241, p. 1050-1059, 2017.

MEZAROBA, S.; MENEGUETTI, C. C.; GTROFF, A. M. Processos de produção do açúcar de cana e os possíveis reaproveitamentos dos subprodutos e resíduos resultantes do sistema. Resumos IV Encontro de Engenharia de Produção Agroindustrial (FENILCAM), v. 1, p. 1-10, 2010.

MOHANA, S.; DESAI, C.; MADAMWAR, D. Biodegradation and decolourization of anaerobically treated distillery spent wash by a novel bacterial consortium. Bioresource Technology, v. 98, n. 2, p. 333-339, 2007.

MORAES, B. S. et al. Anaerobic digestion of vinasse from sugarcane biorefineries in Brazil from energy, environmental, and economic perspectives: Profit or expense? Applied Energy, v. 113, p. 825-835, 2014.

MORAES, B. S.; ZAIAT, M.; BONOMI, A. Anaerobic digestion of vinasse from sugarcane ethanol production in Brazil: Challenges and perspectives. Renewable and Sustainable Energy Reviews, v. 44, p. 888-903, 2015.

MOSEY, F. E. New Developments in the Anaerobic Treatment of Industrial Wastes. v. 81, n. 4, p.540-552, 1982. 
MOSEY, F. E. Mathematical modelling of the anaerobic digestion process: regulatory mechanisms for the formation of short-chain volatile acids from glucose. Water Science and Technology, v. 15, p. 209-232, 1983.

NASR, N. et al. Comparative assessment of single-stage and two-stage anaerobic digestion for the treatment of thin stillage. Bioresource Technology, v. 111, p. 122-126, 2012.

NUBEL, U. et al. Sequence heteroneities of genes encoding 16S rRNAs in Paenibacillus polymyxa detected by temperature gradiente gel electrophoresis. J. Bacteriol, v. 178, p. 5636-5643, 1996.

O-THONG, S. et al. High-rate continuous hydrogen production by Thermoanaerobacterium thermosaccharolyticum PSU-2 immobilized on heat-pretreated methanogenic granules. International Journal of Hydrogen Energy, v. 33, n. 22, p. 6498-6508, 2008.

ONODERA, T. et al. Development of a treatment system for molasses wastewater: The effects of cation inhibition on the anaerobic degradation process. Bioresource Technology, v. 131, p. 295-302, 2013.

PARK, M. J. et al. Comprehensive study on a two-stage anaerobic digestion process for the sequential production of hydrogen and methane from cost-effective molasses. Renewable Energy, v. 35, n. 12, p. 6194-6202, 2010.

PEÑA, M. et al. Chemical oxidation of wastewater from molasses fermentation with ozone. Chemosphere, v. 51, n. 9, p. 893-900, 2003.

PENTEADO, E. D. et al. Influence of seed sludge and pretreatment method on hydrogen production in packed-bed anaerobic reactors. International Journal of Hydrogen Energy, v. 38, n. 14, p. 6137-6145, 2013.

PERNA, V. et al. Hydrogen production in an upflow anaerobic packed bed reactor used to treat cheese whey. International Journal of Hydrogen Energy, v. 38, n. 1, p. 54-62, 2013.

PISUTPAISAL, N.; NATHAO, C.; SIRISUKPOKA, U. Biological hydrogen and methane production in from food waste in two-stage CSTR. Energy Procedia, v. 50, p. 719-722, 2014. 
RAJESHWARI, K. . et al. State-of-the-art of anaerobic digestion technology for industrial wastewater treatment. Renewable and Sustainable Energy Reviews, v. 4, n. 2, p. 135$156,2000$.

RAPPORT, J.; ZHANG , R.; JENKINS, B M; WILLIAMS, R. B. Current Anaerobic Digestion Technologies Used for Treatment of Municipal Organic Solid WasteCalifornia Integrated Waste Management Board. [s.l: s.n.].

REN, N. et al. Biohydrogen production from molasses by anaerobic fermentation with a pilot-scale bioreactor system. International Journal of Hydrogen Energy, v. 31, n. 15, p. 2147-2157, 2006.

RIPLEY, A. L. E.; BOYLE, W. C.; CONVERSE, J. C. alkalimetric Improved for anaerobic digestion wastes monitoring of high-strenght wastes. v. 58, n. 5, p. 406-411, 1986.

SAADY, N. M. C. Homoacetogenesis during hydrogen production by mixed cultures dark fermentation: Unresolved challenge. International Journal of Hydrogen Energy, v. 38, n. 30, p. 13172-13191, 2013.

SHOW, K. Y.; LEE, D. J.; CHANG, J. S. Bioreactor and process design for biohydrogen production. Bioresource Technology, v. 102, n. 18, p. 8524-8533, 2011.

SIEGUMFELDT, H.; RECHINGER, K. B.; JAKOBSEN, M. Dynamic Changes of Intracellular pH in Individual Lactic Acid Bacterium Cells in Response to a Rapid Drop in Extracellular $\mathrm{pH}$ Dynamic Changes of Intracellular $\mathrm{pH}$ in Individual Lactic Acid Bacterium Cells in Response to a Rapid Drop in Extracellular $\mathrm{pH}$. Applied and Environmental Microbiology, v. 66, n. 6, p. 2330-2335, 2000.

SILES, J. A. et al. Integrated ozonation and biomethanization treatments of vinasse derived from ethanol manufacturing. Journal of Hazardous Materials, v. 188, n. 1-3, p. 247$253,2011$.

SILVA, A. J. et al. Kinetic modeling and microbial assessment by fluorescent in situ hybridization in anaerobic sequencing batch biofilm reactors treating sulfate-rich wastewater. Brazilian Journal of Chemical Engineering, v. 28, n. 2, p. 209-219, 2011.

SILVA, C. E. V. Produção enzimática de frutooligossacarídeos ( FOS ) por leveduras a 
partir de melaço de cana-de-açúcar. Dissertação de mestrado - Escola Superior de Agricultura Luiz de Queiroz. Piracicaba, p. 52 p., 2008.

SOUZA, M. E.; FUZARO, G.; POLEGATO, A. R. Thermophilic Anaerobic Digestion of Vinasse in Pilot Plant Uasb Reactor. Wat. Sci. Tech., v. 25, n. 7, p. 213-222, 1992.

TOUZEL, J. P.; ALBAGNAC, G. Isolation and characterization of Methanococcus mazei strain MC3. FEMS microbiology letters, v. 16, n. 2, p. 241-245, 1983.

TSUJI, A. et al. The Effects of Temperature and $\mathrm{pH}$ on the Growth of Eight Enteric and Nine Glucose Non-Fermenting Species of Gram-Negative Rods. Microbiology and Immunology, v. 26, n. 1, p. 15-24, 1982.

TURKDOGAN-AYDINOL, F. I.; YETILMEZSOY, K. A fuzzy-logic-based model to predict biogas and methane production rates in a pilot-scale mesophilic UASB reactor treating molasses wastewater. Journal of Hazardous Materials, v. 182, n. 1-3, p. 460$471,2010$.

UENO, Y.; FUKUI, H.; GOTO, M. Operation of a two-stage fermentation process producing hydrogen and methane from organic waste. Environmental Science and Technology, v. 41, n. 4, p. 1413-1419, 2007.

UNICA. União da Indústria de cana-de-açúcar. Produção: por safra. Disponível em: <www.unicadata.com.br>. Acesso em: 16 jan. 2017.

VACCARI, G. et al. Overview of the environmental problems in beet sugar processing: Possible solutions. Journal of Cleaner Production, v. 13, n. 5 SPEC. ISS., p. 499-507, 2005.

VILELA, R. S. Produção de Hidrogênio e metano a partir de subproduto da indústria sucroalcooleira, em reatores anaeróbios de fases separadas sob condição termofílica. tese ( doutorado). Escola de Engenharia de São Carlos.Universidade de São Paulo, 2017.

VLISSIDIS, A.; ZOUBOULIS, A. I. Thermophilic anaerobic digestion of alcohol distillery wastewaters. Bioresource Technology, v. 43, n. 2, p. 131-140, 1993.

WANG, B.; LI, Y.; REN, N. Biohydrogen from molasses with ethanol-type fermentation: Effect of hydraulic retention time. International Journal of Hydrogen Energy, v. 38, n. 11, p. 4361-4367, 2013. 
WANG, J.; WAN, W. Factors influencing fermentative hydrogen production: A review. International Journal of Hydrogen Energy, v. 34, n. 2, p. 799-811, 2009.

WIEGEL, J.; TANNER, R.; RAINEY, F. A. An Introduction to the Family Clostridiaceae. In: DWORKIN., M. et al. (Eds.). . The Prokaryotes, Bacteria: Firmicutes, Cyanobacteria. U.S.: Springer, 2006. p. 654-678.

WU, C. W. et al. Fermentative biohydrogen production from lactate and acetate. Bioresource Technology, v. 113, p. 30-36, 2012.

WU, L. J. et al. Comparison of hyper-thermophilic-mesophilic two-stage with single-stage mesophilic anaerobic digestion of waste activated sludge: Process performance and microbial community analysis. Chemical Engineering Journal, v. 290, p. 290-301, 2016.

WU, S.-Y. et al. Fermentative hydrogen production and bacterial community structure in high-rate anaerobic bioreactors containing silicone-immobilized and self-flocculated sludge. Biotechnology and Bioengineering, v. 93, n. 5, p. 934-946, 2006.

WU, X.; LIN, H.; ZHU, J. Optimization of continuous hydrogen production from cofermenting molasses with liquid swine manure in an anaerobic sequencing batch reactor. Bioresource Technology, v. 136, p. 351-359, 2013.

ZHANG, D. et al. Bioreactor performance and methanogenic population dynamics in a low-temperature $\left(5-18^{\circ} \mathrm{C}\right)$ anaerobic fixed-bed reactor. Bioresource Technology, v. 104, p. 136-143, 2012.

ZOETEMEYER, R. J.; VAN DEN HEUVEL, J. C.; COHEN, A. pH influence on acidogenic dissimilation of glucose in an anaerobic digestor. Water Research, v. 16, n. 3, p. 303-311, 1982. 